\title{
Active Thrusting and Folding Along the Northern Tien Shan and Late Cenozoic Rotation of the Tarim Relative to Dzungaria and Kazakhstan
}

\author{
J. P. AVOUaC ${ }^{1}$ AND P. TAPPONNIER, \\ Laboratoire de Tectonique, Institut de Physique du Globe de Paris \\ M. BAI \\ Seismological Bureau of Xinjiang, People's Republic of China \\ H. You AND G. WANG, \\ Xinjiang Engineering Institute, People's Republic of China
}

\begin{abstract}
We have studied geometries and rates of late Cenozoic thrust faulting and folding along the northern piedmont of the Tien Shan mountain belt, West of Urumqi, where the $M=8.3$ Manas earthquake occurred on December 23, 1906. The northern range of the Tien Shan, rising above $5000 \mathrm{~m}$, overthrusts a flexural foredeep, filled with up to $11,000 \mathrm{~m}$ of sediment, of the Dzungarian basement. Our fieldwork reveals that the active thrust reaches the surface $30 \mathrm{~km}$ north of the range front, within a $200-\mathrm{km}$-long zone of NeogeneQuaternary anticlines. Fault scarps are clearest across inset terraces within narrow valleys incised through the anticlines by large rivers flowing down from the range. In all the valleys, the scarps offset vertically the highest terrace surface by the same amount $(10.2 \pm 0.7 \mathrm{~m})$. Inferring an early Holocene age $(10 \pm 2 \mathrm{kyr})$ for this terrace, which is continuous with the largest recent fans of the piedmont, yields a rate of vertical throw of $1.0 \pm 0.3 \mathrm{~mm} / \mathrm{yr}$ on the main active thrust at the surface. A quantitative morphological analysis of the degradation of terrace edges that are offset by the thrust corroborates such a rate and yields a mass diffusivity of $5.5 \pm 2.5 \mathrm{~m}^{2} / \mathrm{kyr}$. A rather fresh surface scarp, $0.8 \pm 0.15 \mathrm{~m}$ high, that is unlikely to result from shallow earthquakes with $6<M<7$ in the last 230 years, is visible at the extremities of the main fold zone. We associate this scarp with the 1906 Manas earthquake and infer that a structure comprising a deep basement ramp under the range, gently dipping flats in the foreland, and shallow ramps responsible for the formation of the active, fault propagation anticlines could have been activated by that earthquake. If so, the return period of a 1906 type event would be $850 \pm 380$ years. The small size of the scarp for an earthquake of this magnitude suggests that a large fraction of the slip at depth $(\approx 2 / 3)$ is taken up by incremental folding near the surface. Comparable earthquakes might activate flat detachments and ramp anticlines at a distance from the front of other rising Quaternary ranges such as the San Gabriel mountains in California or the Mont Blanc-Aar massifs in the Alps. We sestimate the finite Cenozoic shortening of the folded Dzungarian sediments to be of the order of $30 \mathrm{~km}$ and the Cenozoic shortening rate to have been $3 \pm 1.5 \mathrm{~mm} / \mathrm{yr}$. Assuming comparable shortening along the Tarim piedmont and minor additional active thrusting within the mountain belt, we infer the rate of shortening across the Tien Shan to be at least $6 \pm 3 \mathrm{~mm} / \mathrm{yr}$ at the longitude of Manas $\left(\approx 85.5^{\circ} \mathrm{E}\right.$ ). A total shortening of $125 \pm 30 \mathrm{~km}$ is estimated from crustal thickening, assuming local Airy isostatic equilibrium. Under the same assumption, serial N-S sections imply that Cenozoic shortening across the belt increases westwards to $203 \pm 50 \mathrm{~km}$ at the longitude of Kashgar $\left(\approx 76^{\circ} \mathrm{E}\right)$, as reflected by the westward increase of the width of the belt. This strain gradient implies a clockwise rotation of Tarim relative to Dzungaria and Kazakhstan of $7 \pm 2.5^{\circ}$ around a pole located near the eastern extremity of the Tien Shan, west of Hami $\left(\approx 96^{\circ} \mathrm{E}, 43.5^{\circ} \mathrm{N}\right)$, comparable to that revealed by paleomagnetism between Tarim and Dzungaria $\left(8.6^{\circ} \pm 8.7^{\circ}\right)$. A $6 \mathrm{~mm} / \mathrm{yr}$ rate of shortening at the longitude of Manas would imply a rate of rotation of $0.45 \% \mathrm{~m}$.y. and would be consistent with a shortening rate of 12 $\mathrm{mm} / \mathrm{yr}$ north of Kashgar. Taking such values to be representative of Late Cenozoic rates would place the onset of reactivation of the Tien Shan by the India-Asia collision in the early to middle Miocene $(16+22 /-9$ m.y.), in accord with the existence of particularly thick late Neogene and Quaternary deposits. Such reactivation would thus have started much later than the collision, roughly at the time of the great midMiocene changes in tectonic regimes, denudation and sedimentation rates observed in southeast Asia, the Himalayas and the Bay of Bengal, and of the correlative rapid change in seawater $\mathrm{Sr}$ isotopic ratio (20 to 15 Ma). Like these other changes, the rise of the Tien Shan might be a distant consequence of the end of Indochina's escape.
\end{abstract}

\section{INTRODUCTION}

The collision between India and Asia has caused intense deformation within the Asian continent. Landsat image interpretation, earthquake fault plane solutions, and a limited number of field studies indicate that the ongoing convergence

\footnotetext{
${ }^{1}$ Now at Laboratoire de Détection Géophysique, CEA, Bruyères-leChâtel, France.
}

Copyright 1993 by the American Geophysical Union.

Paper number 92JB01963. 0148-0227/93/92JB01963\$05.00 between India and Siberia (50-55 mm/yr [De Mets et al., 1990]) is absorbed both by crustal thickening and strike-slip extrusion [e.g., Molnar and Tapponnier, 1975; Tapponnier and Molnar, 1977; Molnar and Deng, 1984; Peltzer et al., 1985, 1988; Armijo et al., 1986]. In the western part of the collision zone, eastward extrusion of Tibet, chiefly between the left-lateral Altyn Tagh and right-lateral Karakorum faults, appears to account for $\approx 30 \%$ of that convergence [Armijo et al, 1989; Peltzer et al., 1989; Molnar and Lyon-Caen, 1989], with the rest being absorbed by crustal thickening south and north of these faults, in the Himalayas and in central Asia. 
By comparison with the Himalayas, for which the present-day kinematics and mechanics of overthrusting are broadly understood [e.g., Lyon-Caen and Molnar, 1983, 1985; Armijo et al., 1986], active crustal thickening processes in central Asia are poorly known. That much of this thickening occurs in the Tien Shan seems clear, however.

The Tien Shan is the longest and highest mountain belt of central Asia. It is composed of several parallel ranges that stretch east-west for nearly $2500 \mathrm{~km}$ between the Kyzil Koum and Gobi deserts, with peaks rising generally to about $4500 \mathrm{~m}$, and to more than $7000 \mathrm{~m}$, north of Aksu (Figure 1). To the north and south, it is flanked by sedimentary basins, most prominently the deep Kashgar and Aksu-Kucha basins in the Tarim, and the south Dzungarian basin (Figure 1). From satellite images [Tapponnier and Molnar, 1979] and published geological maps [e.g., Chen et al., 1985; Akademiya Nauk SSSR, 1964], the recent tectonics of the Tien Shan appear to be dominated by thrusting on roughly E-W striking faults and by folding of Cenozoic sediments, particularly along the piedmonts of the ranges (Figure 1). Where the Tien Shan is highest, north of Aksu, negative, $1^{\circ} \times 1^{\circ}$ average Bouguer gravity anomalies are $\approx 50 \mathrm{mGal}$ greater than expected from local isostatic equilibrium of a thickened crust. Burov et al. [1990] interpret this to indicate that in the Aksu region at least, sinking of cold mantle material pulls the central Tien Shan down.

The high level of historical and instrumental seismicity implies that crustal deformation in the Tien Shan is rapid. During the last hundred years, four great earthquakes (Chilik, $M \approx 8.5$, July 12 , 1889 ; Atushi, $M \approx 8.6$, August 22,1902 ; Manas, $M \approx 8.3$, December 23, 1906; Kebin, $M \approx 8.7$, January 3, 1911) and five shocks with $M>7$ have occurred [e.g., Institute of Geophysics, 1976; Akademiya Nauk SSSR, 1962; Molnar et al., 1973; Molnar and Deng, 1984]. Fault-plane solutions and centroid depth determinations [Ni, 1978; Tapponnier and Molnar, 1979; Nelson et al, 1987; Ekström and England, 1989] are compatible with shortening nearly perpendicular to the overall trend of the belt and consistent with the idea that the Tien Shan overthrusts the Tarim to the south, and Kazakhstan and Dzungaria to the north (Figure 2). By summing inferred moments of four earthquakes with $M>7.5$ in the last 90 years, Molnar and Deng [1984] have estimated the present day shortening rate across the Tien Shan to be $13 \pm 7 \mathrm{~mm} / \mathrm{yr}$.

In order to place tighter constraints on rates and processes of crustal shortening and thickening in the Tien Shan, detailed studies of Tertiary and Quatemary deformation in the field, which to date have been few [e.g., Bai and Fang, 1981], are needed. Here we present the results of a field study of active thrust faulting and folding along the northern piedmont of the Tien Shan, in the epicentral region of the December 23, 1906, $M=8.3$, Manas earthquake, west of Urumqi (Figure 2).

Our mapping of active faults and folds was guided by the morphological analysis of SPOT images. Structural observations made in the field along six north-south sections are used to investigate the mechanism by which the Tien Shan overthrusts the Dzungarian basin. From the precise topcgraphic levelling of offset alluvial terraces, complemented by quantitative analysis of the degradation of scarp profiles under the action of erosion, we derive an estimate of the vertical throw rate along the main thrust at the surface, and infer the recurrence time of events comparable to the 1906 earthquake [Avouac et al., 1990]. Finally, starting from the Manas area, and assuming essentially compensated topography and local sedimentation along the belt, we place bounds on the finite amount of shortening on sections across the whole Tien Shan, from east to west, since it was reactivated in the Cenozoic, as well as bounds on the finite amount and rate of clockwise rotation of the Tarim relative to Kazakhstan and Dzungaria [Avouac et al., 1990].

\section{GEOLOGY AND TECTONICS OF THE DZUNGARIAN} TIEN SHAN

\section{Regional Geology, Stratigraphy and Structure}

The Dzungarian Tien Shan is composed of two main ranges, the Boro Horo and Bogdo Shan, separated by a left step at the Urumqi saddle that tails into the Turfan basin (Figures 1 and 2). Both ranges exhibit extremely youthful morphology. In the Boro Horo Shan, old erosion and deposition surfaces have been uplifted, apparently quite rapidly, to elevations in excess of 4000 $\mathrm{m}$. Their remnants now form outstanding, flat mesas above the snowline. As is the case of several other great mountain ranges of China and central Asia [e.g., Tapponnier et al., 1990] and despite inherited tectonic complexity in the deep basement, both ranges display the simple geometry of large-scale, crustal-size anticlines, with progressively younger geological strata warping the more ancient cores of the mountains. Such geometry is particularly clear at the western, periclinal termination of Bogdo Shan, which is uniformly enveloped by terrigenous Permian sediments, with generally steep outward dips, as well as around the eastern end of the Boro Horo range, which is wrapped by Permo-Triassic and lower Jurassic beds [Chen et al., 1985].

In the Boro Horo Shan south of Hutubi (Plate 1) and within the Bogdo Shan near Tian Chi lake, Carboniferous andesitic agglomerates and tuffs (up to $3000 \mathrm{~m}$ thick) make up a large part of the mountain core [Liao et al., 1987]. Gabbros form the highest peaks of Bogdo Shan [Chen et al., 1985] (Plate 1). These rocks represent evidence of an island arc, which formed an active margin south of Dzungaria in the late Carboniferous [e.g., Carroll et al., 1990; Windley et al., 1990]. In the central Tien Shan, between Urumqi and Korla, Windley et al. [1990] distinguish two sutures of different ages and opposite vergence (late Devonian and north dipping in the south; late Carboniferous and south dipping in the north) (Plate 1). Steeply dipping mylonites and sheared melange imply postcollisional strike-slip movement along the northern suture west of Turfan [Windley et al., 1990; M. Mattauer, personal communication, 1987]. On geologic maps [Chen et al., 1985] (Plate 1) and Landsat images, this suture corresponds to a linear, WNW striking, $\approx 700-\mathrm{km}$-long fault zone (referred to as Tien Shan fault by Carroll et al. [1990]). Clockwise warping of steeply dipping, Carboniferous volcanic tuffs on the maps and the images imply dextral shear along this zone [Windley et al.,1990], which may be related to the dextral Dzungarian fault [Voitovich, 1969; Tapponnier and Molnar, 1979] (Figure 1). The northeastern edge of Dzungaria appears to be marked by two other sutures, also of Late Devonian and Late Carboniferous age, along the Altai and Kelameili Shan, respectively [Chen et al., 1985; Carroll et al., 1990; B. Windley, personal communication, 1990] (Plate 1). Finally, a belt of upper Paleozoic ophiolites follows the northwestern edge of Dzungaria, west of Karamai [Chen et al., 1985] (Plate 1 ). The triangular Dzungarian block is thus surrounded on all sides by sutures, some showing evidence of strike-slip reactivation (Plate 1). In spite of probably complex accretion-collision processes, the most recent field studies support the view that the Kazakh, Dzungar, Tarim, and intervening blocks were welded together by the Permian [e.g., Norin, 1937, 1941; Burtman, 1975; Zhang and $\mathrm{Wu}, 1985]$.

The last known marine sediments in the Dzungarian Tien Shan are Early Permian stromatolites. In the southeastern part of the Bogdo range, andesitic volcanism continued into the Middle Permian, but the lava flows are interbedded with continental conglomerates. In the northwestern Bogdo Shan, continental, Lower to Middle Permian mudstones (with fossil mudcracks), siltstones, and fine sandstones (up to $2000 \mathrm{~m}$ thick) grade into 


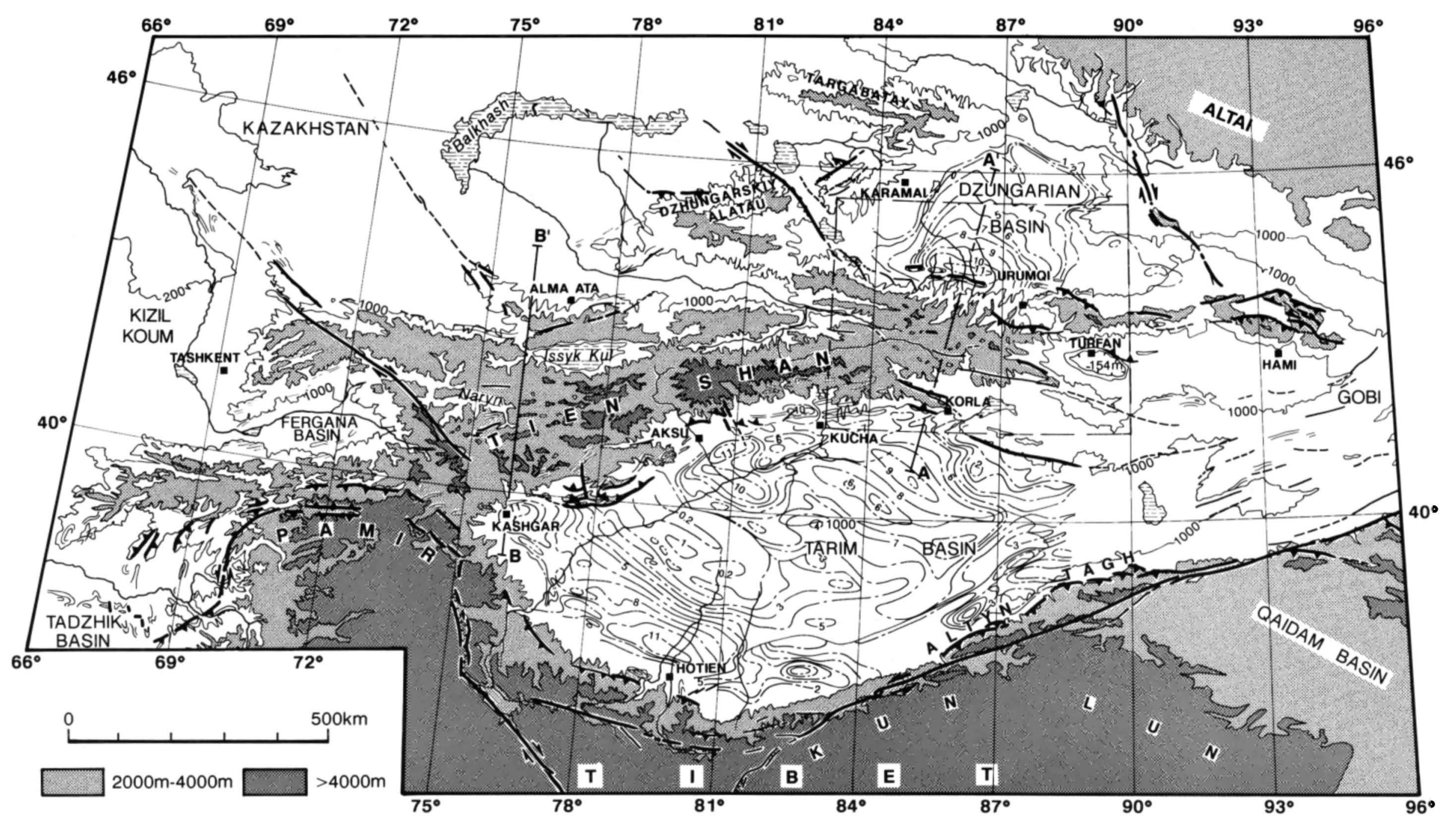

Fig. 1. Active tectonics and topography of Central Asia. Active faults and folds are from fieldwork and analysis of Landsat and SPOT images (modified from Tapponnier and Molnar [1979]). Topography is from Times Books [1978]. Isopachs of and SPOT images (modified from Tapponnier and Molnar [1979]). Topography is from Times Books [1978]. Isopachs of location of area shown in Plate 1 and Figure 2. 


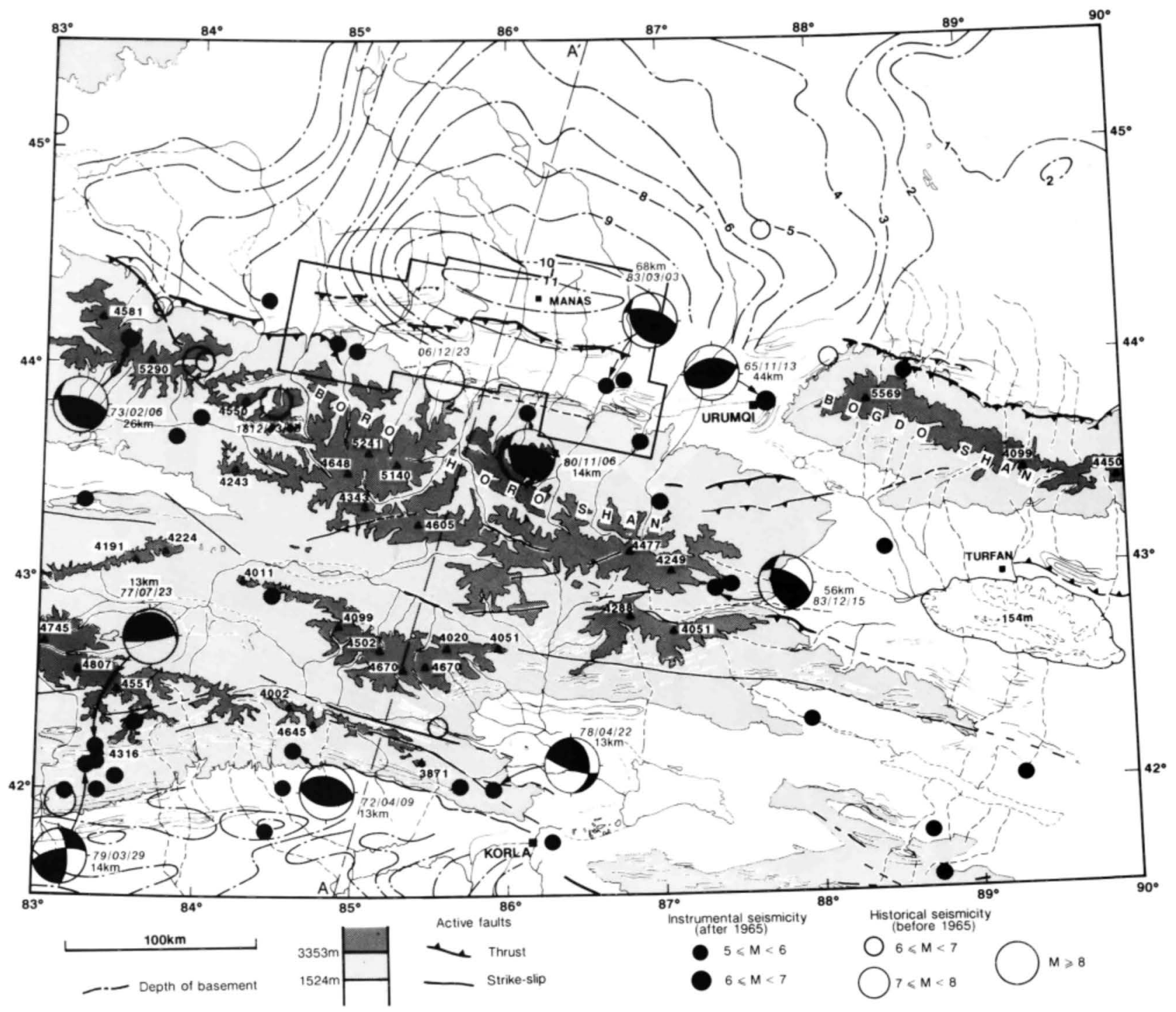

Fig. 2. Seismotectonic map of Central Tien Shan. Seismicity prior to 1965 (open circles) is from Institute of Geophysics [1976]. Seismicity after 1965 (solid circles) from WWSSN. Fault planes solutions are from Nelson et al. [1987] and Ekström and England [1990]. Numbers indicate dates and focal depths. Faults, topography, and sediment isopachs are from same sources as in Fig. 1. Box indicates location of area shown in Figure 3. AA' is crustal section of Figure 27.

upper Permian lacustrine oil shales (up to $1000 \mathrm{~m}$ thick) and are capped by a few hundred meters of coarser Permo-Triassic conglomerates and sandstones that appear to have prograded towards the northeast [Carroll et al., 1990]. These Permian sediments, which postdate the final, upper Carboniferous suturing of the Dzungarian Tien Shan, may have filled distal flats in a subsiding foreland basin [Graham et al., 1989; Carroll et al., 1990; Windley et al., 1990].

Continental sedimentation persisted from the Triassic onwards. The Triassic and Jurassic crop out in elongated, now intramontane, basins (Ili, Korla, Turfan basins), along the northern foothills of Boro Horo and Bogdo shan and south of Kelameili Shan (Plate 1). West of Urumqi, the middle-upper Jurassic sequence, which comprises the Totuen He, Qigou, and Karazha formations [Wang, 1985; Peng and Zhang, 1989; Chen et al., 1991] is up to $3100 \mathrm{~m}$ thick [Wu Z., 1986]. It is composed of massive, medium-grained, red sandstones grading upwards into finer greenish sandstones that include paralic coal horizons. The coal has often burned where exposed at the surface along the piedmont, turning the clayrich host rocks into red brick. South of Urumqi, at Houxia, rapid variations in the thickness of the coal beds attest to normal faulting during the middle Jurassic (B. Windley, personal communication, 1990). South of Shihozi, unconformable, relatively flat Jurassic strata still cap parts of the Boro Horo range [Chen et al., 1985].

Upper Mesozoic and Tertiary sediments crop out along the foothills of that range and in the core of piedmont anticlines farther north (Figure 2 and Plates 1-3). The Cretaceous, mostly composed of the Hutubi, Shengiinkou, Lianmuqin, and Donggou formations, whose thicknesses add up to $1900 \mathrm{~m}$ [Dong, 1973; Chen et al., 1985; Wu Z., 1986; Peng and Zhang, 1989; Chen et al., 1991] is conformable with the Jurassic underneath. It starts with fine dark red sandstones and conglomerates containing angular clasts that grade into variegated and light green sandtones. The Hutubi formation contains ostracods of probable Barremian age, while the Lianmuqin and Donggou formations have yielded fauna including, respectively, the typically Asian Psitaccosaurus, of probable Albo-Aptian age, and Hadrosaurs of probable Santonian to Maastrichtian age [Chen et al., 1985; Hao et al., 1986; Chen et al., 1991; Buffetaut et al., 1989]. 


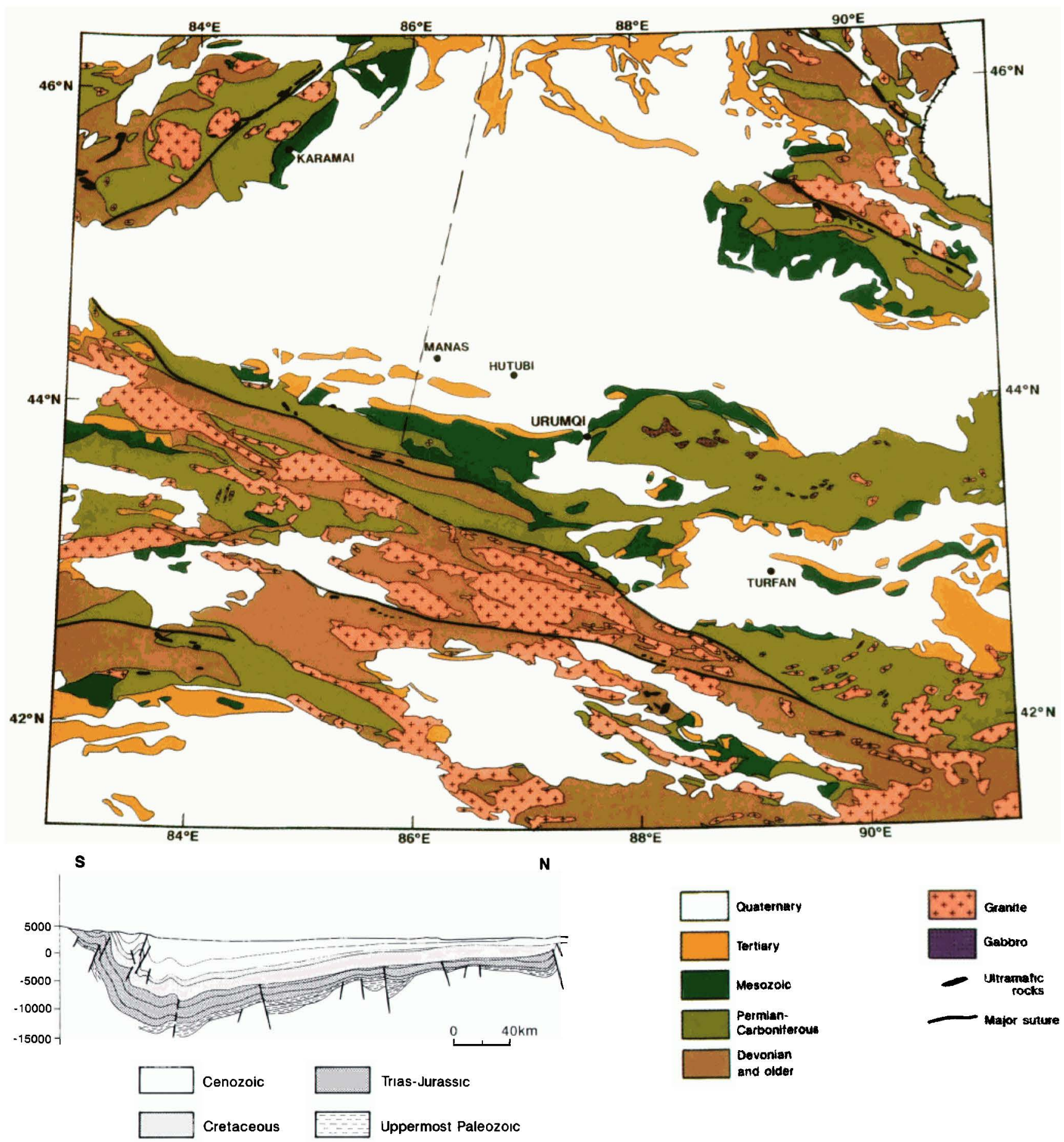

Plate 1. Simplified geologic map of Dzungaria and surrounding mountain regions, [from Chen et al., 1985; Windley et al., 1990]. Note prominent sutures on all sides of Dzungaria. Inset shows roughly $\mathrm{N}-\mathrm{S}$ section of Dzungarian basin, interpreted from seismic reflection studies [after $W u Z$., 1986; Peng and Zhang, 1989]. Note North-tapering Cenozoic sedimentary wedge and pre-Cretaceous high-angle faults.

Resting conformably upon the upper Cretaceous sandstones, brick-red gypsiferous mudstones and sandstones with thin layers of bioclastic limestones [Peng and Zhang, 1989], followed by green and red terrigenous sandstones form the base of the Tertiary (up to $900 \mathrm{~m}$ thick [Wu Z.,1986]). These rocks (Zhiniquan and Anjihai $\mathrm{He}$ formations), which contain gastropods and bivalves, are considered to be of PaleoceneEocene to Oligocene age [ $\mathrm{Li}, 1984$; Peng and Zhang, 1989; Chen et al., 1991].

The Neogene (Shawan, Tashi He, and Dushanzi formations) is up to $2800 \mathrm{~m}$ thick [ $W u Z$., 1986]. It is composed of more homogeneous, less consolidated siltstones and sandy mudstones, with more uniform, brownish-pink shales that become lighter upwards. The bulk of that thick sequence probably belongs to the upper Miocene and Pliocene [Peng and Zhang, 1989]. Irregular conglomeratic discharges with dark, well-rounded pebbles, probably reflecting greater proximity of relief, appear in the upper part of the sequence, thought to correspond to the upper Pliocene. There is no trace along the Dzungarian Tien Shan of the marine, foraminifera-bearing, Miocene beds found in the southwestern Tien Shan (Kashgar, Fergana).

Coarse, dark grey, lower Quaternary conglomerates reach a thickness of $2400 \mathrm{~m}$ [Wu Z., 1986; Peng and Zhang, 1989]. These conglomerates (Xiyu formation) make a morphologically 
resistant horizon that often forms the jagged crests of the south limbs of anticlines in the piedmont of the Boro Horo range. They are analogous to the thick and strong regional conglomerate found $1000 \mathrm{~km}$ to the west along the southern piedmont of the Tien Shan in the Kashgar-Atushi area. It is probable that such powerful conglomeratic discharges, which contain cobbles and boulders of large size, reflect the onset of the ice age on the nearby mountains and of concurrent, more voluminous mass wasting towards the adjacent lowlands. In other words, they reflect a climatic, rather than tectonic, change.

South of the Hutubi-Dushanzi road, more recent Quaternary deposits (light-grey fluvial gravels and conglomerates and yellowish sands and silts) have either accumulated in the piedmont synclines, trapped into piggy-back basins south of the growing anticlines, or form thinner terraces and fans that rest unconformably upon most Mesozoic and Cenozoic rocks.

\section{Tectonic History}

Overall, the regional geology and stratigraphy imply that suturing of this part of central Asia was complete in the Early Permian. The collision between Dzungaria and continental blocks south of it formed the northeastern Tien Shan. Uplift within this mountain belt, and north vergent overthrusting concurrent with deepening of a flexural foredeep along the southern edge of Dzungaria probably continued into the Middle Permian [Watson et al., 1987; Windley et al., 1990].

Although a more peaceful regime of continental sedimentation in a less active tectonic environment prevailed during the Mesozoic, there is convincing evidence of localized faulting in the Triassic and Lower-Middle Jurassic [Peng and Zhang, 1989; Bally et al., 1986]. In addition to faulting during deposition of the coal beds in the Tien Shan, high-angle faults clearly offset the pre-upper Jurassic-Lower Cretaceous sedimentary sequence on seismic reflection profiles in the Dzungarian basin (Plate 1, inset). In fact, fault-controlled thickness changes of up to a few thousand meters appear to characterize the Triassic and LowerMiddle Jurassic sedimentation [Peng and Zhang, 1989; Hendrix et al., 1992]. Along the Hongshan-Baikouquan fault zone, west of Karamai, high angle thrusts cut Triassic and Lower-Middle Jurassic strata and are unconformably covered by the uppermost Jurassic and Cretaceous [e.g., Wu Q., 1986; Bally et al., 1986]. Some Triassic to Mid-Jurassic thrusting may also have occurred along the Bogdo and Boro Horo Shan [Peng and Zhang, 1989; Carroll et al., 1990]. Typically, however, pre-Tertiary folding of Triassic-Jurassic horizons is rare and most of the faults appear to be normal faults limiting half-graben (e.g., Lunan halfgraben[Peng and Zhang, 1989; Bally et al., 1986]). Jurassic movement has long been inferred along the Talasso-Fergana fault in the western Tien Shan. Burtman [1980] interprets the two narrow troughs filled by a few kilometers of terrigenous Jurassic sediments at the extremities of the fault as pull-apart basins that resulted from right-lateral slip along the fault. Intracontinental faulting, mostly strike-slip and normal, thus appears to have characterized the Triassic and Jurassic periods over much of the Tien Shan and Dzungaria. Such deformation may have been a consequence of greater coeval movements along the boundaries of the Central Asian plate, particularly in northern Mongolia and southeastern Siberia, in keeping with mounting geological and paleomagnetic evidence that welding of that plate with the Angaran continent was completed only in the upper-middle Jurassic period [Kosygin and Parfenov, 1981; Khramov, 1987; Enkin et al., 1992].

Widespread deposition of Upper Mesozoic continental clastics continued to fill most of the Paleozoic and Lower Mesozoic basins, including the wider Dzungarian and Tarim basins, and ultimately covered much of the Paleozoic orogen [Windley et al.,
1990; Bally et al., 1986]. By contrast with sediments deposited before and after, however, the Cretaceous and lower Tertiary rocks are rather thin, mature deposits of fairly uniform thickness [Peng and Zhang, 1989]. There has been general agreement that most of the relief in this part of central Asia had been smoothed out by the end of the Mesozoic and that the Cretaceous and early Tertiary were particularly quiet tectonic periods [Krestnikov, 1962; Norin, 1941; Burtman, 1975; Peng and Zhang, 1989; Bally et al., 1986].

Most authors also agree that Paleozoic and Mesozoic structures were reactivated after the Eocene [Chang, 1959; Goryachev, 1959; Krestnikov, 1962; Burtman, 1975], as a result of the collision between India and Asia [e.g., Molnar and Tapponnier, 1975; Tapponnier and Molnar, 1979]. The onset of the presently active compressional tectonic regime however, is not known with precision [Windley et al., 1990]. The unconformity of Oligocene conglomerates along parts of the eastern Tien Shan has been interpreted to mark the beginning of regional crustal shortening, but it seems likely that the onset of strong topographic uplift and related subsidence took place rather late in the Miocene, especially in the northern Tien Shan [Hendrix et al., 1992]. Along the Dushanzi-Hutubi piedmont for instance, the Neogene and Quaternary reach thicknesses in excess of $5000 \mathrm{~m}$ [Wu Q., 1986; $W u Z$., 1986; Peng and Zhang, 1989] (Plate 1, inset), and conglomerates become abundant only within the Plio-Quaternary. It is possible that shortening and uplift accelerated markedly in the Pliocene, but whatever the case, the Neogene and Quaternary make up the largest fraction of the Cenozoic clastic sequence and about half the total thickness of the post-Paleozoic sedimentary column along the northem foreland of the Tien Shan. A similar situation appears to exist along the Tarim piedmont of the Tien Shan, where Cenozoic deposits represent two thirds of the volume of the post-Paleozoic sediments [Tian et al., 1989; Bally et al., 1986], and recent folds, particularly near Kashgar and between Aksu and Korla, affect mostly the Neogene and Quatemary [Chen et al., 1985].

Depth contours derived from seismic reflection studies [Wu $Z ., 1986$; Peng and Zhang, 1989] show that the Upper Paleozoic acoustic basement of Dzungaria dips gently towards the Tien Shan (Figures 1 and 2) [Chen et al., 1985]. At a large scale on north-south seismic sections, the overlying Mesozoic sediments form a south dipping monocline of rather constant thickness, save for moderate thickening of the Jurassic towards the south [Wu Z., 1986; Bally et al., 1986; Peng and Zhang, 1989], (Plate 1 , inset). By contrast, late Cenozoic deposits, particularly the Neogene and Quaternary, make a wedge that tapers northwards from maximum thickness at the foot of Boro Horo Shan to a thin blanket, over a distance of about $200 \mathrm{~km}$ (Plate 1, inset). This tapering wedge is most simply related to loading of the southern edge of Dzungaria by Neogene to Quaternary overthrusting along the Tien Shan [e.g., Bally et al., 1986]. The resulting flexural basin is deepest between Hutubi and Dushanzi, where the basement is overlain by more than $11 \mathrm{~km}$ of continental clastics (Figure 2), with about half that thickness assigned a Late Cenozoic age [Wu Z., 1986; Peng and Zhang, 1989]. Only here has a conspicuous fold and thrust belt formed within the piedmont sediments (Figures 1 and Plates 1 and 2), implying that only where these sediments are thickest has deformation migrated far into the foreland .

Although it has been suggested that the Dzungarian basin is underlain by oceanic basement trapped between colliding blocks at the end of the Paleozoic [e.g., Hsï, 1989; Carroll et al., 1990], neither the depth of the Moho nor the moderate thickness of pre-Tertiary sediments on top of the acoustic basement in the middle of the basin (about $40 \mathrm{~km}$ according to $M a$ [1987] and 4- 
$6 \mathrm{~km}$ according to Peng and Zhang [1989], respectively (Plate 1 , inset)) make this hypothesis compelling.

\section{LATE CENOZOIC FOLDING AND FAULTING NORTH OF BORO HORO SHAN}

\section{Recent Folding Along the Hutubi-Dushanzi Piedmont}

The varied, colorful lithology of the upper Mesozoic and Cenozoic as well as the sparse steppe vegetation cover allow detailed mapping of recent folds and faults along the piedmont of the Boro Horo range. Patches, of vegetation remain localized to stream valleys, irrigated flats or crescent-shaped zones of water seepage at the toes of active fans. We used a mosaic of five overlapping, multispectral SPOT images covering the entire piedmont between Dushanzi and Hutubi (Plate 2a) as a base for the map of Plate $2 b$. Once processed, the images, which have a $20 \mathrm{~m}$ ground resolution, accurately reveal most morphological and structural details. Most of the characteristic units described above may also be easily identified from their spectral signatures and textures on the images. Field sections corresponding to six of the rivercut valleys across the piedmont folds are shown in Plate 3. These valleys provide the best exposures of the folded Mesozoic and Cenozoic sediments.

Three distinct rows of anticlines are visible [Chen et al., 1985; Tapponnier and Molnar, 1979] (Plate 2). The first row, along the range front (AO in Plate $2 b$ ), mostly involves sediments as old as middle-upper Jurassic. Within the piedmont, about $30 \mathrm{~km}$ north of the base of the range front, a second row of anticlines (A1, A2, A3, and A4 in Plates 1, 2, and 3) stretches east-west for about $150 \mathrm{~km}$. No formation older than the upper Cretaceous crops out at the core of these anticlines. Northwest of that second row, three contiguous, well-aligned anticlines (A5, A6, and A7 in Plate 2), that fold Neogene and Quaternary deposits form the third row, about $75 \mathrm{~km}$ long, roughly between Shawan and Dushanzi. Finally, mild doming of upper Quaternary surfaces near the western and eastern extremities of the two piedmont fold rows implies the existence of two more, incipient anticlines (A8 and A9 in Plate 2) at the edge of the Dzungarian plain.

The range front row (A0) is in fact composed of several leftstepping folds, with overlapping hinges exposed mostly in upper Jurassic-Lower Cretaceous sandtones (Plate 2). Near the coalmining village of She Chang (Plate 2 and 3), the sandstone beds strike $\mathrm{N} 100-110^{\circ} \mathrm{E}$ and dip generally steeply $\left(60-65^{\circ} \mathrm{N}\right)$ towards the north. West of She Chang on the San Ge Quen section (Plate 3), south dipping thrust faults offset folds in Jurassic and older rocks at the foot of Boro Horo Shan. North dipping strata appear to follow most of the steep north slope of the mountain. Flatter, Lower Mesozoic and upper Paleozoic beds are visible near its summit.

The principal fold row of the piedmont (A1-4, Plate 2) has a rather simple, uniform structure. The slightly overlapping periclines of $A 1, A 2$, and $A 3$ are clearly outlined by the early Tertiary red beds and Lower Quaternary conglomerates on the SPOT images. All three anticlines are asymmetrical, with incomplete, steep northem limbs. All display axial faulting (Plate 2). The fact that the northern limbs of $A 2$ and $A 3$ barely crop out between Jingou $\mathrm{He}$ and Manas $\mathrm{He}$ implies that thrusts offset their hinges. The eyelid geometry of Al (Tugulu anticline) in map view (Plate 2) indicates that a fault ramping through its core has upthrusted its southern onto its northern limb. In the field, on the Qiu Er Gou section, that thrust places south dipping Eocene red beds on top of vertical Neogene beds. On the Tashi He section, it places green upper cretaceous sandstones, dipping $60 \pm 10^{\circ}$ to the south, on overturned Tertiary red beds that show incipient cleavage dipping less steeply than the bedding. Where well exposed, the Tugulu thrust plane strikes $\mathrm{N} 90-105^{\circ} \mathrm{E}$ and dips $50-70^{\circ}$ to the south. Slickensides on the Qiu Er Gou and Hutubi He sections are consistent with a $\mathrm{N} 10^{\circ} \mathrm{E}$ direction of transport and nearly pure dip-slip on the thrust. The thrust that ramps along anticline $A 2$ reaches the surface a few kilometers north of the Tugulu thrust, with which it overlaps in the Manas He valley (Plate 2). On the Linjia He section, steeply north dipping Neogene beds are visible in the hanging-wall of that thrust (Plate 3). In tum, the thrust along anticline A3 is offset from that along $A 2$ (Plate 2). Structures exposed in the core of $A 3$ are slightly more complex than in $A 1$ and $A 2$ (Plate 3 ). On the Jingou He section, green upper Cretaceous sandstones dipping $50-60^{\circ} \mathrm{S}$ have been placed on top of less steeply south dipping Tertiary beds by a thrust striking $\mathrm{N} 90-100^{\circ} \mathrm{E}$ and dipping about $55^{\circ} \mathrm{S}$. The Tertiary beds are tightly folded in a small anticline. A second, parallel, but more steeply dipping thrust places the slightly overturned Tertiary beds of the north limb of that anticline against Quaternary conglomerate.

Overall, the observations and the structure summarized in Plates 2 and 3 suggest that $\mathrm{A} 1, \mathrm{~A} 2$, and $\mathrm{A} 3$ are fault propagation folds [e.g., Suppe and Medwedeff, 1984] that grew concurrently with steep thrusts ramping upwards from a flat decollement (Figure 3). That the three anticlines form $10-15 \mathrm{~km}$ wide topographic bulges (Plate 3), with no net vertical offset of the planar, regional piedmont slope $\left(1.1 \pm 0.1^{\circ} \mathrm{N}\right)$ across them, implies that they fold mostly the top $5-8 \mathrm{~km}$ of. the sedimentary pile (about half of it) and that the steep thrust ramps associated with them do not extend deeper. That folding disappears or becomes very gentle at the base of the Cretaceous on seismic sections [Peng and Zhang, 1989] corroborates this inference. On the other hand, the map and sections in Plates 2 and 3 imply kilometric offsets on the thrust ramps. Because such offsets are too large for faults only a few kilometers deep, the thrust ramps probably root on a shallow south dipping decollement. That the

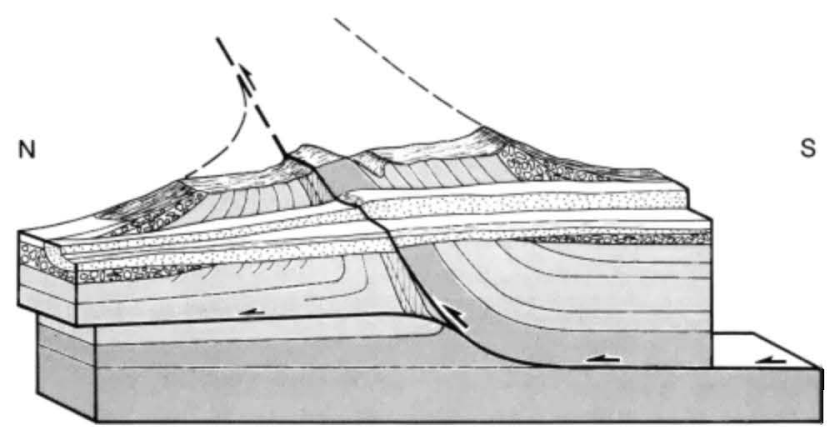

Fig. 3a. Active fault propagation fold geometry of anticlines A1-A3 between Hutubi and Dushanzi is revealed by structure and thrust scarps offsetting Holocene terraces deeply inset in river narrows cutting through hearts of anticlines.

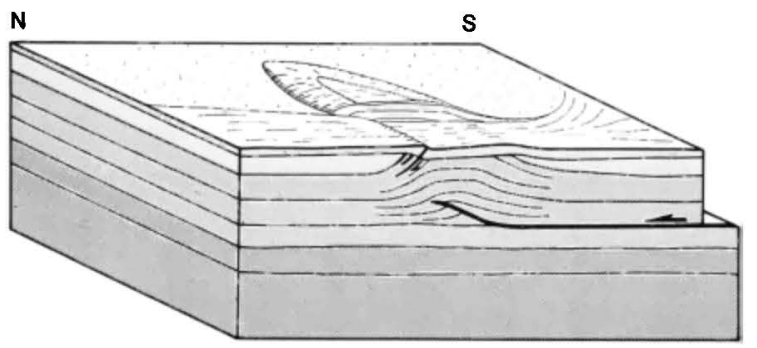

Fig. 3b. Northernmost anticlines A5 and A6 are probably fault propagation folds associated with a shallow blind thrust ramp. Folding induces flexural slip on bedding planes. 
ramps are parallel to upper Cretaceous hanging wall strata on the Jingou He and Tashi He sections implies that this decollement lies at base of upper Cretaceous, at a depth of about 6-7 km (Figure 3).

Anticlines A5, A6, and A7 are more gently expressed in the topography and display less evolved, more symmetrical structures than $\mathrm{A} 1, \mathrm{~A} 2$, and $\mathrm{A} 3$ (Plates 2 and 3). Bedding dips are maximum in the Pliocene strata of their north limbs (up to $35^{\circ} \mathrm{N}$ in A5). No clear south dipping thrust is exposed along these anticlines except along the north edge of $A 7$ west of $85^{\circ} \mathrm{E}$, where the A5-A7 anticlinal row is closest to the range front (20 $\mathrm{km}$ ) and the A1-A4 row terminates (Plate 2). On the Anjihai He section, $\mathrm{N} 10^{\circ} \mathrm{W}$ directed slickensides on a $\mathrm{N} 70^{\circ} \mathrm{E}$ striking, $32^{\circ} \mathrm{N}$ dipping, bedding-parallel thrust in the north limb of $\mathrm{A} 5$ imply flexural slip folding (Plate 3 ). Such a process is compatible with blind thrusting along A5 (Figure 3). Thus, we infer these three anticlines to be less evolved fault propagation folds or even fault bend folds associated with partly blind thrust ramps. Because their widths are only $5-10 \mathrm{~km}$, half to two thirds that of A1-A3, they probably fold a thinner sedimentary sequence and may be associated with a decollement shallower than that inferred south of anticlines A1-A3 (Figure 3).

In summary, the evidence and interpretations above suggest that folding and concurrent thrusting have migrated northwards, away from the Boro Horo range front, during the late Cenozoic. The anticlines probably evolved as fault propagation folds on ramps rooting into flat detachments propagating towards the foreland [Avouac et al,, 1990]. Since the oldest formations brought to the surface along $A O$ are Jurassic, a lowermost sedimentary flat might lie under the Jurassic near the range. It ought to correspond to a particularly weak horizon, such as the upper Permian lacustrine shale, underneath the more competent Mesozoic sandstone sequence. Similarly weak horizons, such as mudstone or clay- and gypsum-rich sandstone within the Cretaceous and Tertiary, appear to have localized shear at shallower and shallower levels northwards from the range. The solution we find most consistent with observations is that anticlines $A 1, A 2$, and $A 3$ formed as fault propagation folds on top of ramps growing from a flat at the base of the upper Cretaceous (Plate 3). The narrower anticlines A5, A6, and A7 reflect folding of a thinner pile detached from the underlying sediments along a shallower flat, probably at the base of the Neogene (Figure 3).

\section{Deposition Pattern and Chronology of Late Quaternary Sediments}

In order to retrieve quantitative information on active folding and thrusting processes, particular attention was paid to the disposition and ages of the late Quaternary formations, which consist of large imbricated fans, inset alluvial terraces, and colluvial slopes. By combining field evidence with morphological analysis of the SPOT images, it was possible to determine the relative chronology of those formations from their modes of emplacement, shades, heights and degrees of incision, and to establish regional correlations between them (Plate 2). The patterns and chronology of alluvial deposition, in turn, yield information on the history of recent folding and faulting.

In general, offlaps within the Neogene-Quaternary sequence in the piedmont folds indicate progressive folding during PlioQuatemary sedimentation, but locally along sections across the southern and the northern limbs of anticlines $A 1$ and $A 3$, patches of gently dipping, fairly coarse conglomerate, which we infer to be of mid-upper Quatemary age (Q2-3), are found to lie unconformably on steep Neogene beds. These patches are often perched tens to hundreds of meters above the present river beds.
This implies that particularly in the vicinity of the largest antecedent rivers, the topography has been abraded and reshaped by fluvial erosion-deposition cycles during the Quaternary. Episodic sequences of erosion and deposition coeval with climatic changes probably suffice to account for these local Quaternary unconformities without invoking pulses of deformation.

The deposits that are trapped in the elongated piggy-back basins south of anticlines $A 1, A 2$, and $A 3$ and between $A 3, A 4$, and A5, A6 (Plate 2) appear to be of middle-upper Pleistocene age (Q2-Q3). They are chiefly composed of fairly thick, fluvioglacial fanglomerates, less coarse than the Xiyu conglomerate. While the original fan morphology of these deposits is still visible in map view (Plate 2), their surface is now capped with a fairly thick loess layer and dissected by stream incision.

Younger alluvial fans (Q4), which are shaded grey and contoured on Plate $2 b$ ( $f 1, f 2, f 3, f 4, f^{\prime} 4, f 5, f 6$ ), have formed mostly north of anticlines A1-A6, often on top of $Q 2-Q_{3}$ alluvium. Four such fans, $11, \mathrm{fB}$, and $\mathrm{f5}, \mathrm{f6}$, that were fed by particularly large rivers, extend respectively across the eastern and western ends of A1 and across the heart of A5-A6 (Plate 2). There, the smooth upper surfaces of these fans are inset in, and lie below those, more incised, of the more ancient $Q 2-Q 3$ fans. In turn, the present river beds are now inset into the Q4 fans that stand abandoned above them. Present alluvial deposition occurs farther north, at the edge of the flat Dzungarian steppe (Plate 2). Thus, to this day, the antecedent rivers fed by the glaciers of Boro Horo Shan have kept incising deeper into the Dzungarian piedmont and reaching farther north into the Dzungarian basin, a fact consistent with the idea that the processes responsible for crustal shortening, uplift, and foreland thrust migration along the Dzungarian Tien Shan continue unabated at present.

The similar surface shade of the Q4 fans on the SPOT images as well as their analogous, smooth morphology, and large size suggest that they were emplaced synchronously in a relatively short fan-building epoch when a large quantity of debris was rapidly supplied by river discharge. Although the surface of these fans is sometimes blanketed by loess, the thickness of that loess blanket rarely exceeds a few tens of centimeters. Because the overall pattern of glacial fluctuations in the Holocene has been one of retreat [Derbyshire, 1987], we infer these particularly prominent fans to have formed at the onset of the Holocene, due to rapid melting of the ice stored on top of Boro Horo Shan during the Würm glaciation, as well as to the establishment of a warmer and probably wetter climate in most of the world at that time $(10 \pm 2 \mathrm{ka})$ [e.g., Fairbanks, 1989; Bard et al., 1990; Gasse et al., 1991]. Climatic changes since that epoch have left more modest traces, such as smaller fans, smaller inset terraces, as well as a subtler morphological imprint in the form of minor rill incision on the surface of the early Holocene fans. Peltzer et al. [1989] were led to similar conclusions when studying large recent fans in the western Kun Lun.

\section{Active Faulting}

We were not granted permission to reach the foot of Boro Horo Shan on the Manas He, Tashi He, Qiu Er Gou, and Hutubi He sections. Where we could do so, as on the Linjia $\mathrm{He}$ and San Ge Quen sections, we found no clear evidence of active, north directed thrust faulting along the range front. Thrust faults cutting through folded Mesozoic beds at the foot of the range on the San Ge Quen section (Plate 3) do not seem to cut overlying Quaternary deposits. Recent terraces within river valleys are not clearly offset either, whether at locations we 
visited in the field or on SPOT images in valleys that we could not explore. Given that the epicenter of the 1906 Manas earthquake is reported to lie southwest of Manas, near She Chang, at the foot of the Boro Horo range [Institute of Geophysics, 1976] (Plates 1 and 2b), the absence of north facing surface scarps along the range front implies that if the earthquake resulted from overthrusting of the Boro Horo range onto Dzungaria, the corresponding thrust must be a deep, blind feature under the edge of that range.

As expected in view of the large magnitude of the 1906 earthquake, however, we saw unmistakable, widespread evidence of strong ground shaking in superficial Quaternary deposits east and west of She Chang, between the Manas He and Jingou He valleys (Plate $2 b$ ). Throughout this region, numerous free-faced normal scarps, several tens of centimeters to over 1 $\mathrm{m}$ high, are observed. The scarps, which are well preserved in the surface loess, generally follow the edges of roughly northsouth karstic depressions, and are consistent with downdrop or compaction of the infill of such depressions. In map view, the orientation of the depressions reflects mostly the deposition fabric (Plate 2) of the underlying Q2-3 fans. Free-faced scarps of greater size are reported to exist in the mountains south of She Chang [Bai and Fang, 1981]. They could have resulted from landsliding in response to ground-shaking. Aternatively, they might have been a consequence of hanging wall extension above a blind thrust under the range.

On Landsat and SPOT images, and from a distance in the landscape, clear traces of north-directed thrusting at the range front are visible beyond the perimeter of our field study, just west of $85^{\circ} \mathrm{E}$ where anticline A4 abuts the steep mountain slope, probably against a lateral ramp (Figure 1 and Plates 1 and 2). They continue farther west [Tapponnier and Molnar, 1979]. A range front thrust may also exist șoutheast of the Hutubi He valley, continuing east of $87^{\circ} \mathrm{E}$ (Plate 2) [Tapponnier and Molnar, 1979].

There is local evidence of Late Quaternary faulting a few kilometers north of the range front, near the western extremity of AO (Plates 2 and 3), but it is incompatible with a southdipping thrust. In the field at this latter locality (San Ge Quen section, Plates 2 and 3), the loess covered surface of the Q2-3 fans is offset $15-20 \mathrm{~m}$ by two scarps facing the mountain. We interpret these rather high cumulative scarps to represent the surface expression of active bedding-parallel thrusts, due to Late Quaternary fold growth, within the underlying steeply north dipping Tertiary beds. Scarps of similar origin have been found in the foothills of the Qilian Shan and Taxueh Shan, in Gansu province [Tapponnier et al., 1990; Meyer, 1991].

It is along anticlines $A 1, A 2, A 3$, and $A 7$ within the piedmont, 20 to $30 \mathrm{~km}$ north of the range front, that the most important regional active faults reach the surface. They essentially correspond to the south dipping ramp thrusts that follow the axes of these anticlines. Their surface traces are particularly sharp and prominent where they cut the early Holocene alluvial fans or the corresponding terraces in the narrows that the antecedent rivers flowing down from the Boro Horo range have cut through the anticlines (HTB, TSH, MNH, SGQ, and JGH, Plates $2 \mathrm{a}$ and 2b), [Avouac et al., 1990]. In fact, were it not for the very young markers that those regularly spaced river valleys provide, unmistakable evidence of present-day activity on the ramp thrusts within the anticlines and quantitative information on the degree of activity of these thrusts would not be available. Thus, although such evidence is lacking in both the Qiu Er Gou and Linjia He valleys where, whether on SPOT images or in the field, we could not identify the early Holocene terraces (Plate 2) and where, in addition, the construction of reservoirs has altered the morphology of the valley floors, we infer the three thrusts along $\mathrm{A} 1, \mathrm{~A} 2$, and $\mathrm{A} 3$ to be active everywhere along strike.
There are several complexities, however. For instance, although the three active ramp thrusts may root on a single flat at depth, their surface traces are separated by discontinuous steps between the folds (Plate 2) and, at a smaller scale, within the folds. In the Jingou He valley, recent inset terraces are offset only along the northernmost thrust.

The thrust along $\mathbf{A 7}$, which is marked by clear scarps across and west of fan $f 6$, lies more than $20 \mathrm{~km}$ northwest of $\mathrm{A3}$. A northwest trending zone of left-stepping, en échelon scarps cuts across f6 south of the trace this latter thrust and merges with it just east of Dushanzi. Irrigation channels follow a similarly trending zone across fan 55 south of A5. It is possible that these two zones lie above active, dextral lateral ramps connecting the $A 3$ and A7 thrusts across $f 6$ and the upper part of f5. This inferred geometry would mimic that of the range front.

\section{QUANTITATIVE STUDY OF HOLOCENE THRUST OFFSETS}

\section{Topographic Measurements}

In order to place bounds on rates of vertical throw along segments of the main thrust fault, we measured offset elements of the morphology at places where these segments cut fans or terraces inferred to be of Holocene age. The eight sites we found adapted to such measurements, which are labelled after the principal rivers (HTB, TSH, MNH, LJH, SGQ, JGH, AJH, DSZ; Plate $2 b$ ), span the entire piedmont foldbelt from east to west.

Topographic profiles were levelled across fault scarps and terrace risers, using a high precision, digital-recording theodolite-distancemeter (Wild T 2000, DI 3000). The regional slope, the maximum scarp slope, and the vertical offset of the topographic surface were determined for each profile as shown on Figure 4. In general, the regional slopes ( $B$ in Figure 4 ) of the fans on which we profiled scarps were found to be less than $4^{\circ}$, typically between 0.5 and $2^{\circ}$, on either side of the scarps. In such cases, the measured vertical offset is nearly equal to the vertical throw on the fault, independent of fault dip. Similarly, because terrace risers trend roughly parallel to the rivers, which flow along the direction of steepest slope, the regional slope on profiles transverse to such risers is generally less than a few percent. As a result the height of a terrace riser is nearly equal to the difference in elevation between the two terrace levels it separates.

The levelling procedures and related uncertainties have been discussed by Peltzer et al. [1988]. Given the intrinsic precision of the instrument and the scale of the area surveyed, instrumental errors are only of the order of $1 \mathrm{~cm}$, which leaves the roughness of the topographic surface as the main source of uncertainty. Terrace fanglomerates at the foot of the Tien Shan form such smooth surfaces that the amplitude of the natural topographic noise on measured elevations rarely exceeds $10 \mathrm{~cm}$. The uncertainty on the offsets depends in fact only weakly upon elevation uncertainties. The offset is obtained by linear extrapolation of the far-field topography on each side of the scarp onto a vertical plane passing in the middle of the scarp (Figure 4). Only if the topography is far from planar or if the scarp is very degraded will such extrapolation be fraught with error. These two circumstances are the main sources of error for scarps that are several meters high. For simplicity in the estimation of errors, we have distinguished different classes of profiles. The error on the offset derived from a given profile is considered as the sum of two terms. The first term depends on the roughness of the profile. Since all profiles were levelled on alluvial surfaces which are nearly planar and little disturbed by erosion, this term is generally small. It is set to $0.1 \mathrm{~m}, 0.2 \mathrm{~m}$ or 
$0.5 \mathrm{~m}$ by inspection of the regularity of the surfaces. The second term is proportional to scarp height. It depends on the degree of degradation of the scarp and on the difference in regional slope angles on either side of it. Again by inspection, this relative uncertainty is set to $5 \%, 10 \%$, or $20 \%$ of the height. We assume Gaussian distributions of uncertainties and take error bars of $1 \sigma$. Where the same offset is derived from several adjacent profiles, the average value is computed as a weighted mean,

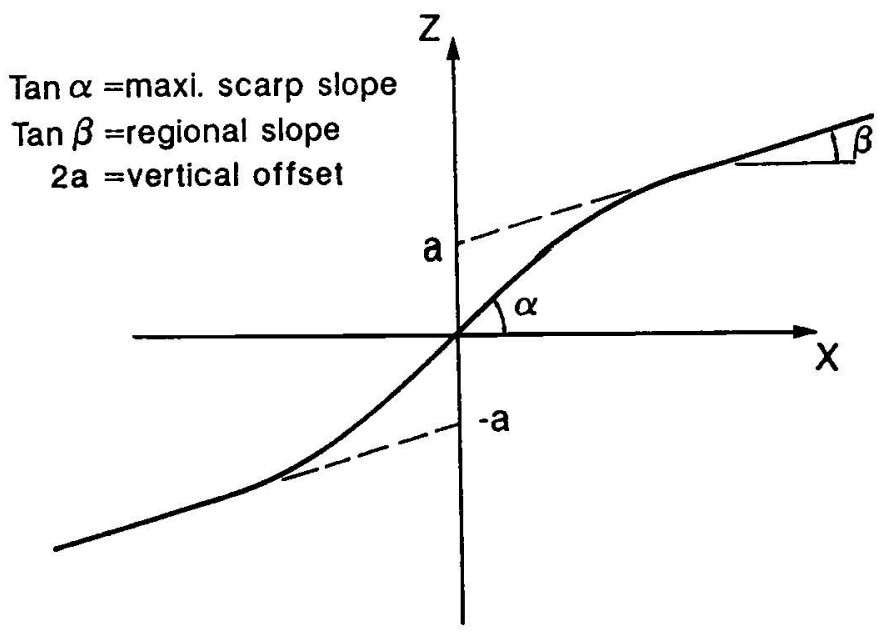

Fig. 4. Definition of measurements derived from scarp profiles and reported in Tables 1 and 2. where

$$
[x]=\left[\sigma^{2}\right] \sum_{i=1}^{n} \frac{x_{i}}{\sigma_{i}^{2}}
$$

$$
\frac{1}{\left[\sigma^{2}\right]}=\sum_{i=1}^{n} \frac{1}{\sigma_{i}^{2}}
$$

\section{Hutubi Site (HTB)}

At this site, just west of the Hutubi river channel, a prominent scarp across fan $\mathrm{f} 1$ marks the surface trace of the Tugulu thrust (Plate 2 and Figures $5 a$ and $5 b$ ). A smaller surface break continues along strike into the valley of the Hutubi river (Figures 5 and 6). Small pressure ridges along that break and a fresh scarplet at the base of the large scarp in $\mathrm{f} 1$ imply ground rupture by a recent thrust earthquake (Figures $6 b, 6 d$, and $6 e$ ). By comparison with other thrust earthquake scarps in central Asia [Meyer, 1991], the still disrupted vegetation cover and the existence of rodent holes in the loose soil along that rupture suggest to us an event less than a few hundred years old. Across f1, the cumulative scarp makes a large, sharp topographic step (Figures $6,7 a$ and $7 c$ ). The lack of lateral offsets of small transverse gullies (Figure 5), confirms the inference derived from slickensides that movement on the thrust is purely dip slip. Slickensides are clear on the well exposed $\mathrm{N} 105^{\circ} \mathrm{E}$ striking, $50^{\circ} \mathrm{S}$ dipping thrust plane along the irrigation channel at the edge of the Hutubi He floodplain. That plane is roughly parallel to the scarp in map view $\left(112^{\circ} \mathrm{E}\right)$ and to hanging wall Pliocene mudstone and conglomerate beds in section.

At a more detailed level, entrenchment of the Hutubi river has left successive inset terraces, whose upper surfaces and risers

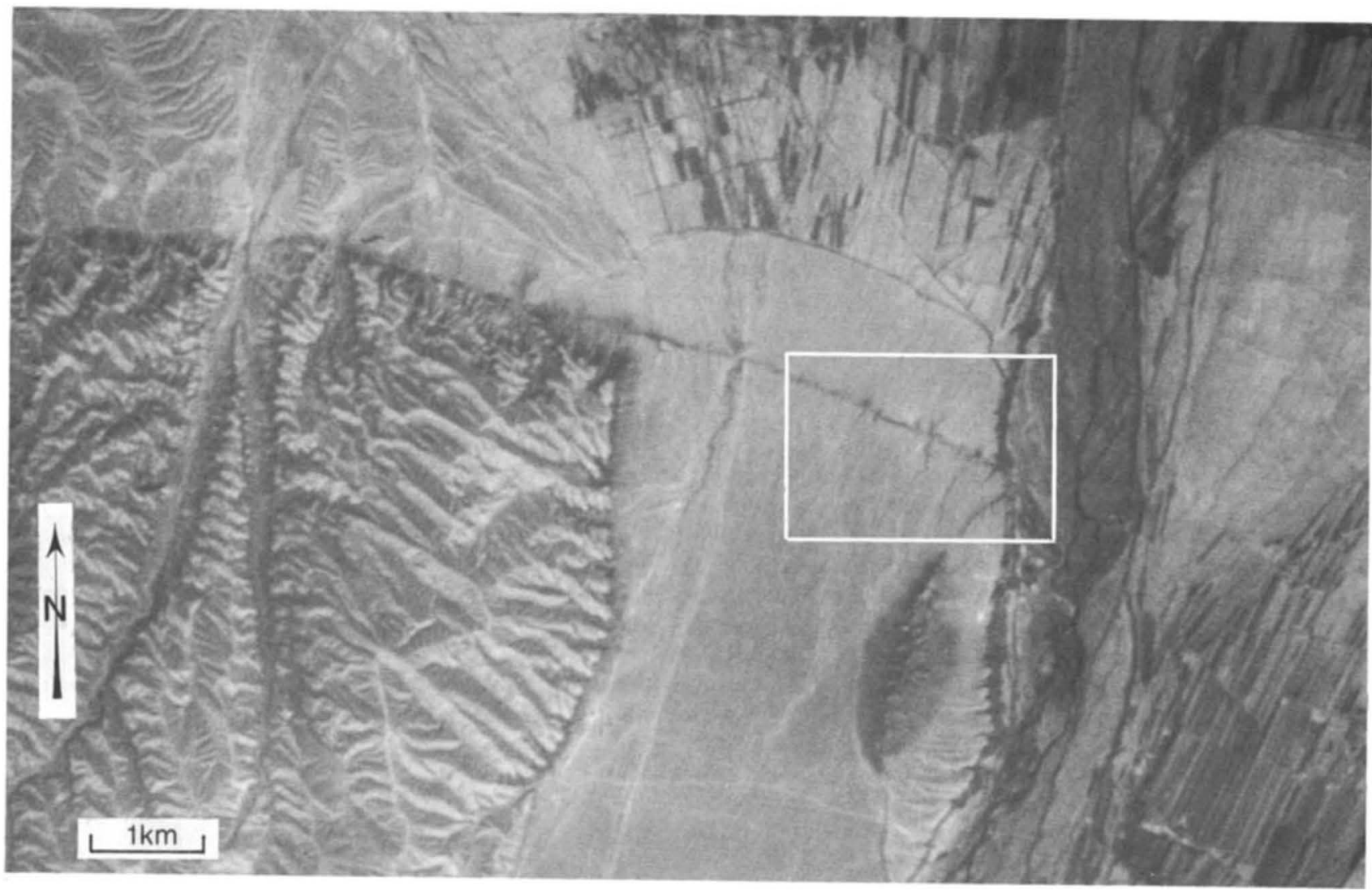

Fig. 5a. Satellite view of late Quaternary thrust scarp across inset terraces of Hutubi He narrows (site HTB, Plate 2a; enlarged XS SPOT image KJ 216-261, August 30,1986, pixel size $20 \mathrm{~m}$ ). Box is area where field measurements of morphology were
made. 
are clear on the SPOT image and in the field. The terrace surfaces are vertically offset across the thrust by different amounts, with the higher ones being more offset than the lower ones, due to fault slip throughout the period of terrace deposition. The highest surface (Q3, Figure $5 b$ ) forms only an isolated tongue north of a midvalley Q1-2 spur (Plate 2 and Figure $5 a$ ) that has protected it from wash by the river. This
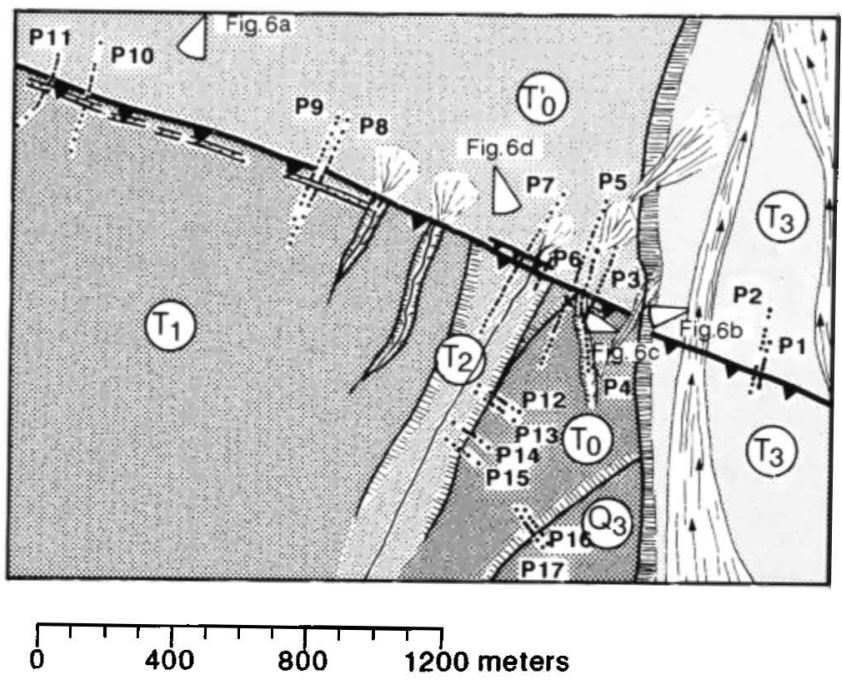

Fig. $5 b$. Sketch map of box in Figure $5 a$ showing main morphological features (including terrace levels TO to T4) and locations of levelling profiles P1 to P17. surface, which stands above that of $\mathrm{fl}$, is the last remnant of a terrace older than $\mathrm{fl}$, hence older than Holocene according to the regional, climatic correlation inferred from the SPOT images (Plate 2). All the other surfaces, which are labelled T0, T1, T2, $\mathrm{T}^{\prime} \mathrm{O}$, and T3 in order of decreasing elevation (Figures $5 b$ and 7) are inferred to be of Holocene age.

Terrace T3 lies $8-10 \mathrm{~m}$ above the present river bed. Numerous, vegetated braided channels on the surface of that terrace imply that it was still submitted to relatively intense and frequent wash, probably by flood of the river itself, in the recent past. The fresh seismic scarplet visible across T3 has a height of $0.8 \mathrm{~m}$ east of the TO-T'0 riser (profiles P1 and P2, Figure $7 a$ ). This height decreases farther eastwards.

South of the thrust, the composite upper surface of $\mathrm{f} 1$ comprises surfaces $\mathrm{T} 0, \mathrm{~T} 1$, and $\mathrm{T} 2$. These surfaces have been uplifted $\approx 7$ to $\approx 12 \mathrm{~m}$ relative to the more uniform fan surface T'O north of the thrust scarp, which stands about $30 \mathrm{~m}$ above T3 (profiles P3 to P11, Figure 7a). The fan surface is only mildly dissected by local, seasonal channels that do not drain water from the Boro Horo range. Small gullies have developed along the thrust by progressive headward erosion away from the scarp (Figure 5). P4 (Figures $5 a$ and 7a), one example of profile along such gullies, displays knickpoints. Whether such knickpoints are due to lithological contrasts in the fan deposits or represent the receding traces of different earthquake generated scarps is not known. The recent seismic scarplet near the base of the cumulative scarp on profiles P6 and P7 (Figures $7 a, 6 d$, and $6 e$ ) is about $1.1 \mathrm{~m}$ high, a height comparable to that of the fresh scarp across T3 and of the lowermost knickpoint on P4. A wellpreserved hinge graben is visible near the top of the cumulative scarp on profiles P9, P10 and P11 (Figure 7a). This graben appears to be due to recent hanging wall extension and collapse, probably above a shallow ramp flat bend on the active thrust (see insert in Figure 7a).

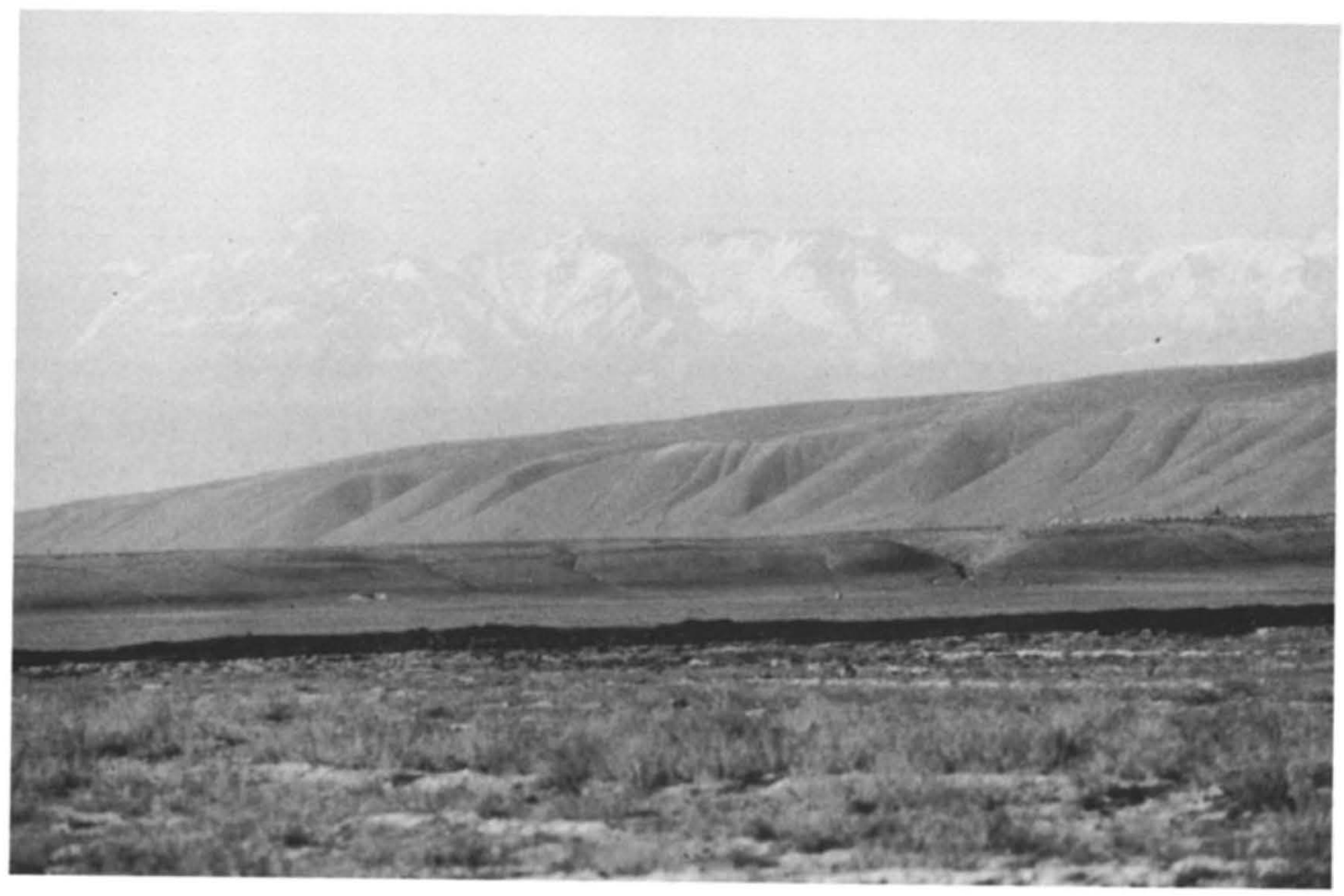

Fig. 6a. South looking view of west part of thrust scarp limiting terrace T2 at site HTB. Sheep on top of scarp at right give scale. Note uplifted upper Pleistocene in middle ground and snow-capped, $\approx 4500$-m-high Tien Shan range in background. 


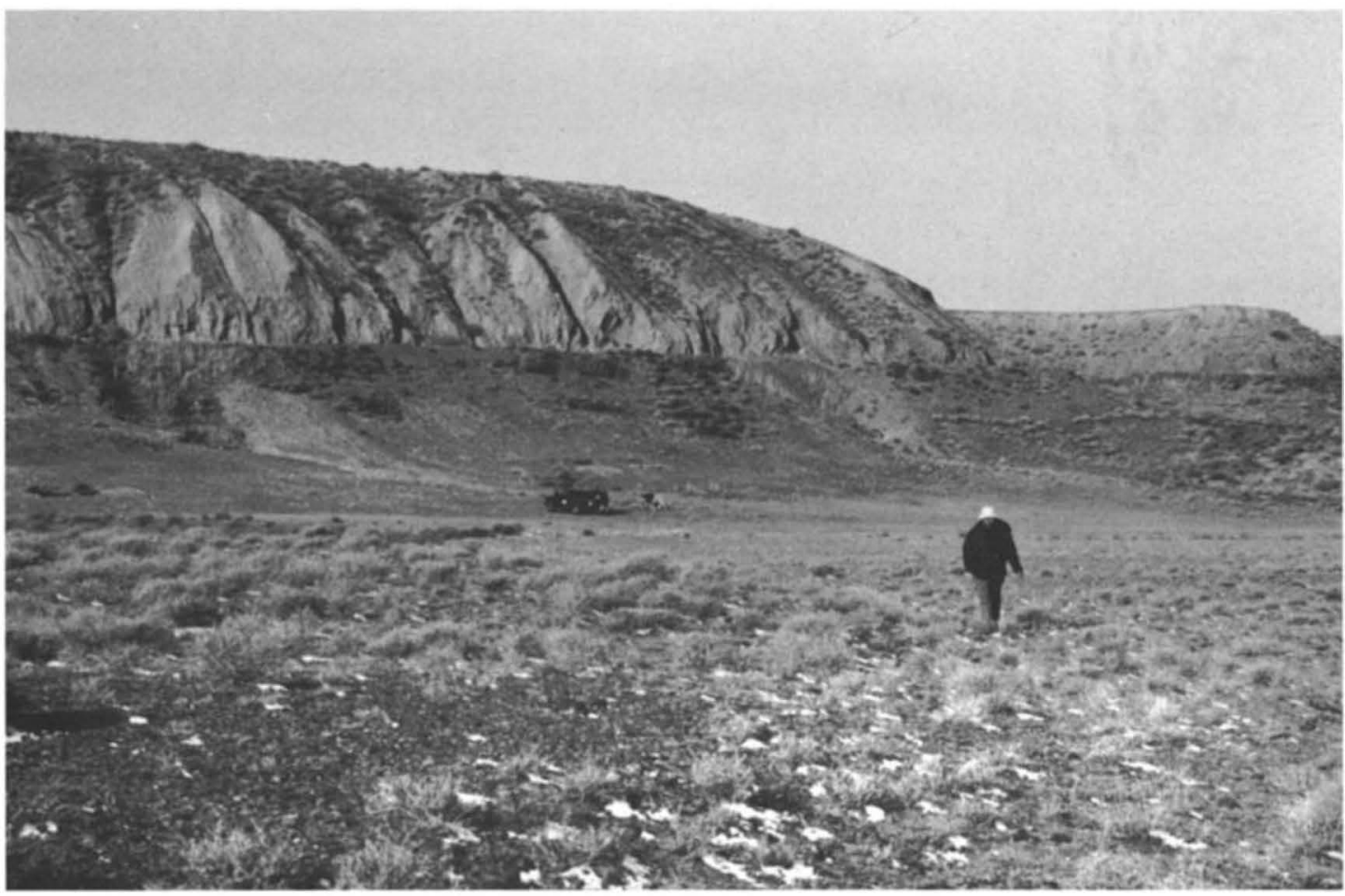

Fig. $6 b$. West looking view of offset fan surface.

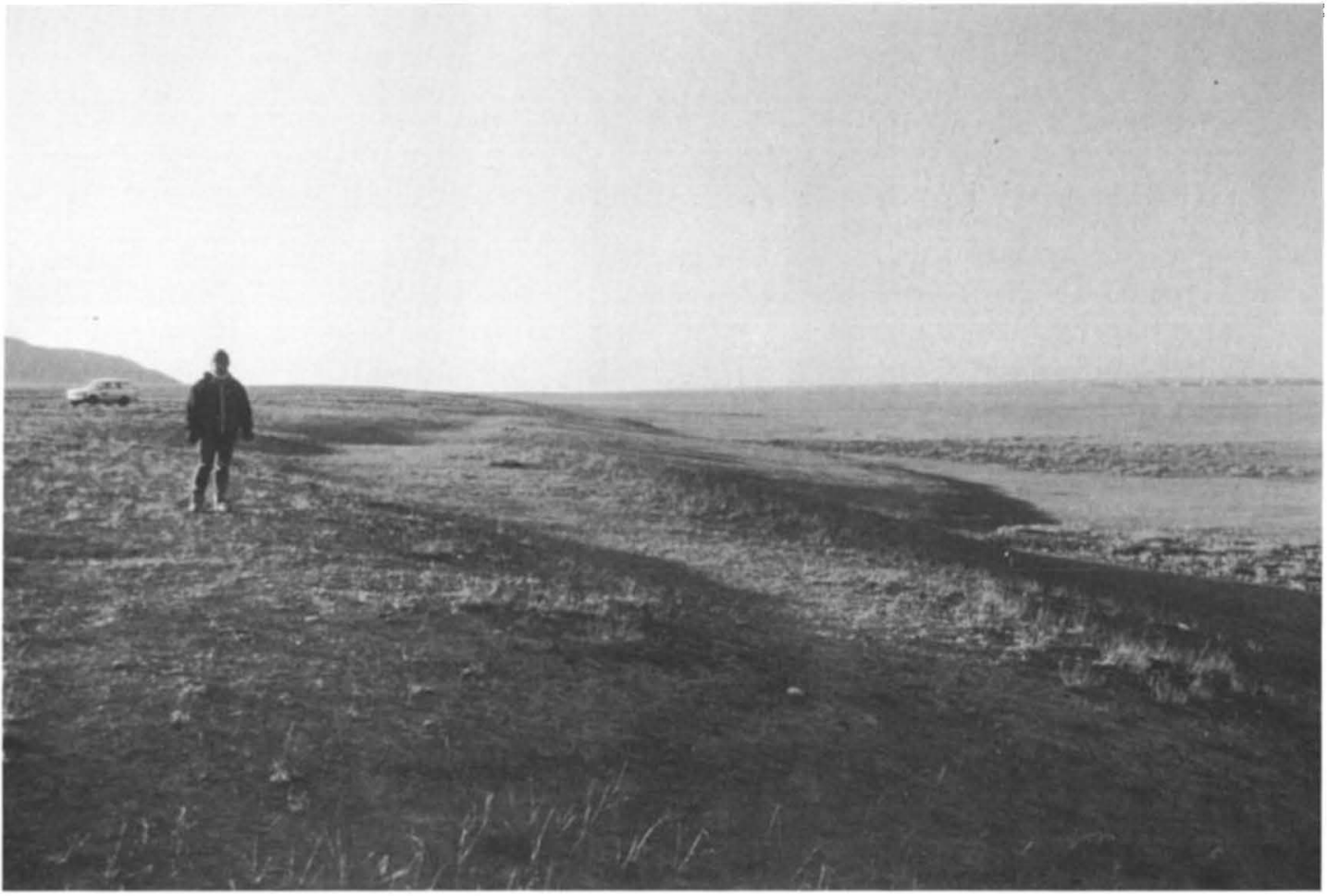

Fig. $6 c$. West looking view of hinge graben on top of cumulative thrust scarp (see P9-11 and corresponding sketch on Figure $7 a)$. 


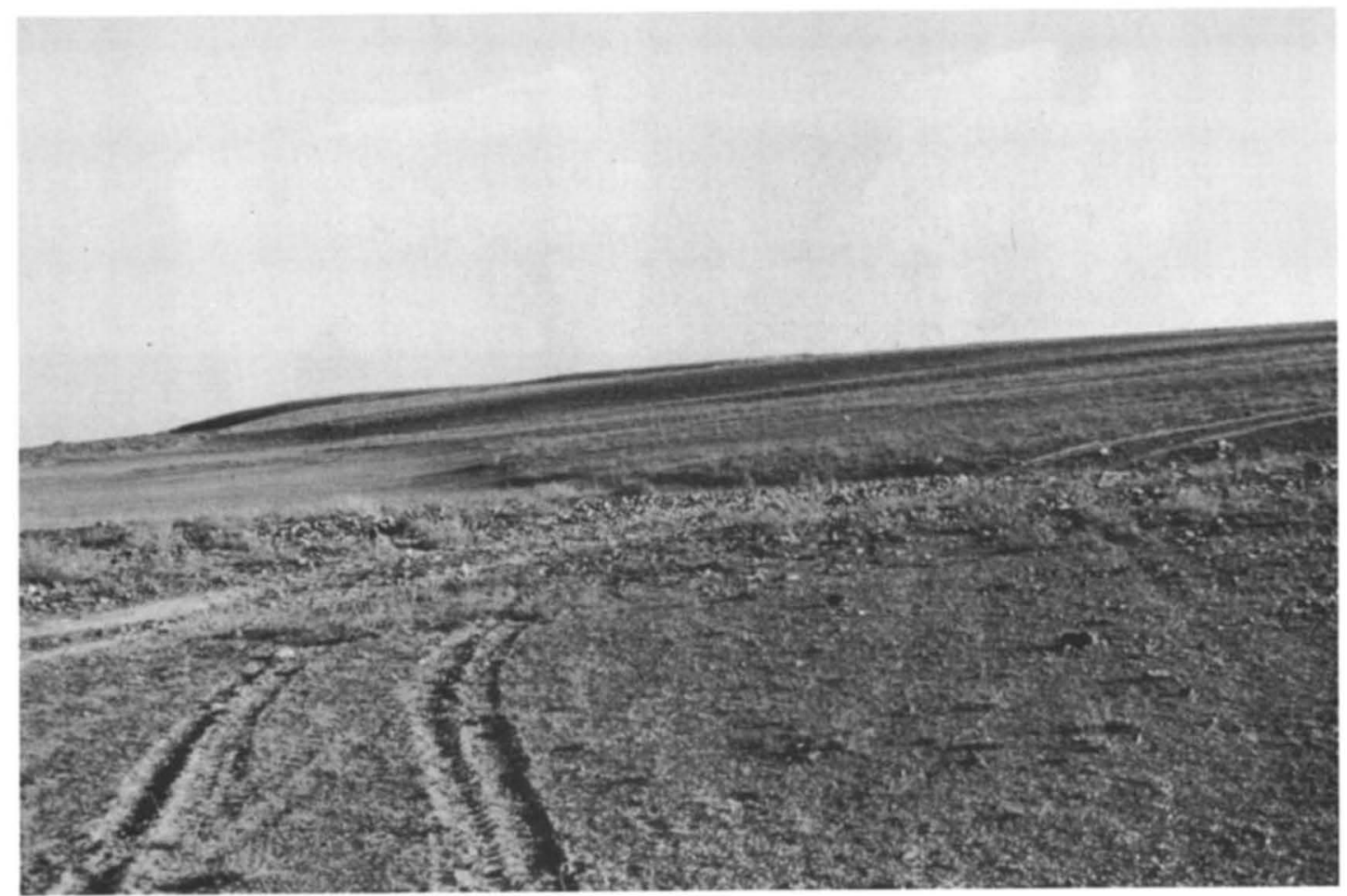

Fig. 6d. East looking view of recent seismic surface break at base of cumulative scarp (see sketch 8e and P6 and P7 in Figure 7a).

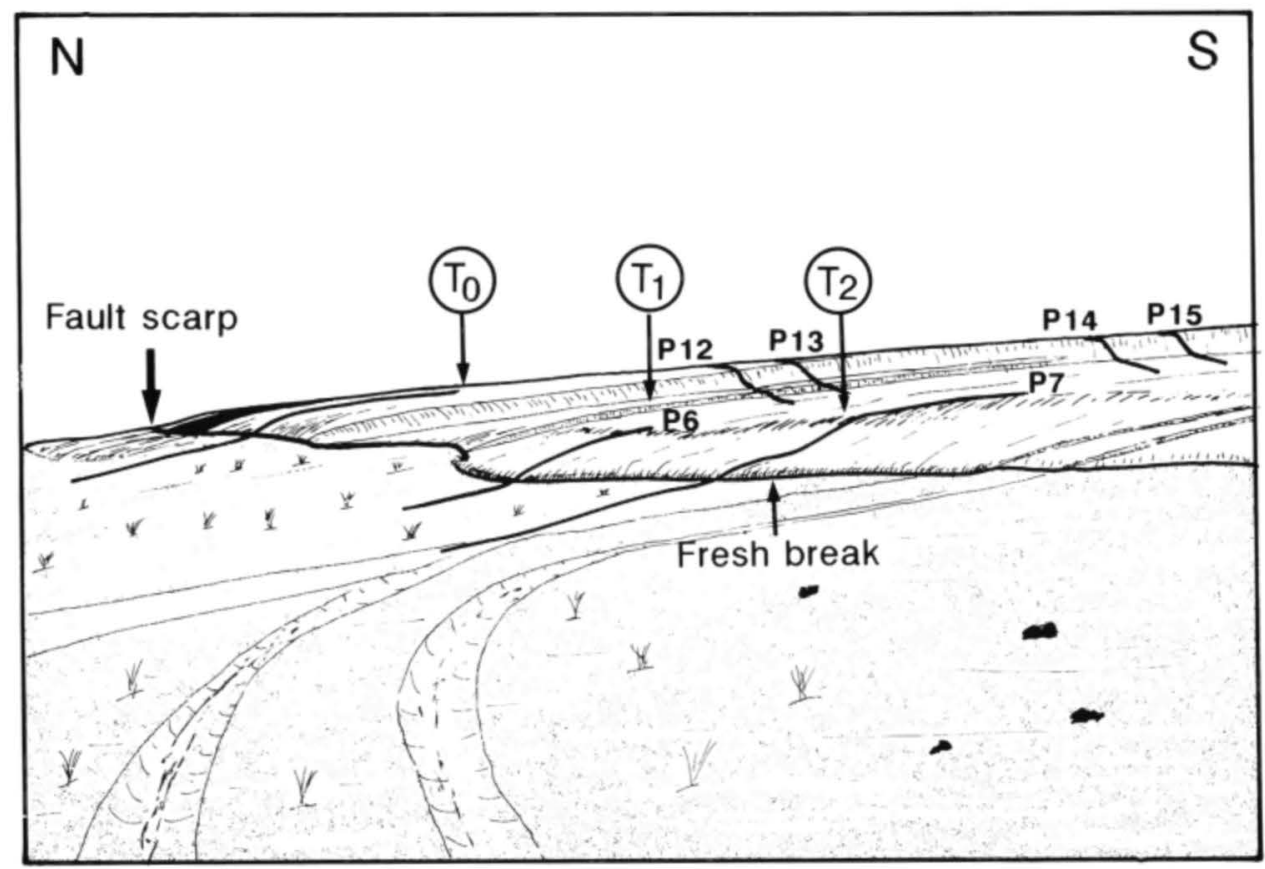

Fig. 6e. Sketch of Figure $6 d$.

The profiles yield rather precise values of all the offsets recorded by the various markers across the fault scarp (Figure $7 a$ and Table 1). The heights of all the uplifted terrace surfaces relative to one another and relative to ' $\mathrm{T}$ ' 0 are also rather well constrained by the profiles (Figures $7 b$ and $7 c$ ). On average, T0 and $\mathrm{T} 1$ have been tectonically uplifted $11.1 \pm 0.6 \mathrm{~m}$ and $8.5 \pm 0.2 \mathrm{~m}$, respectively, above $T^{\prime} 0$ (Figure $7 a$ and Table 1 ). $T 2$, flat floor of the deepest channel on the upper surface of $f 1$ at the site, has been uplifted $6.7 \pm 0.8 \mathrm{~m}$ above $T^{\prime} 0$. The mean uplift of $\mathrm{Q} 3$ above $\mathrm{T}^{\prime} 0,15.6 \pm 1 \mathrm{~m}$, is obtained by adding the 


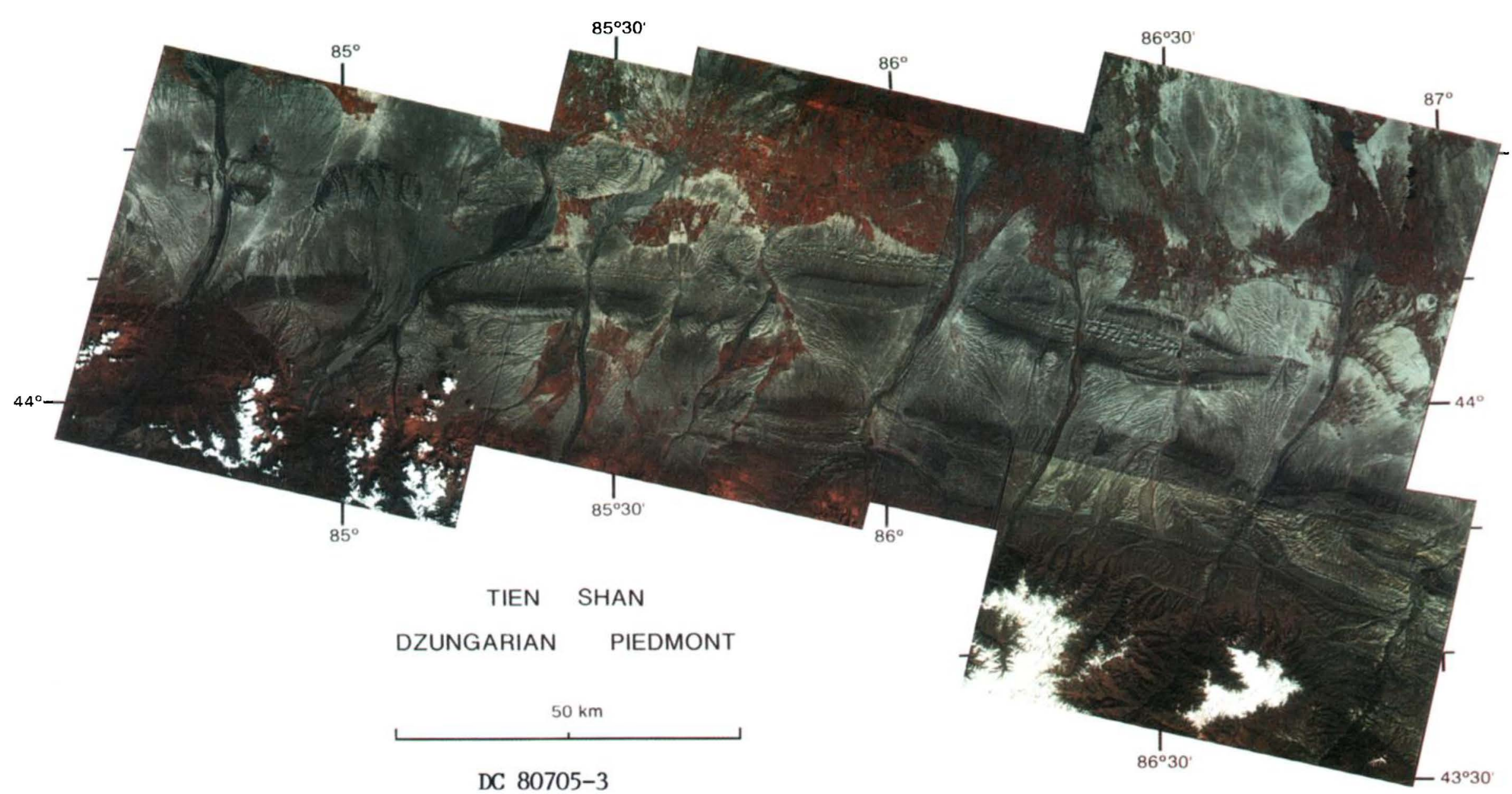

Plate 2a. Multispectral (XS) SPOT image mosaic of fieldwork area, west of Urumqi (box in Figure 2). Scene KJ numbers are 213-261; 214-261; 215-261; 216-261; 216-262. 


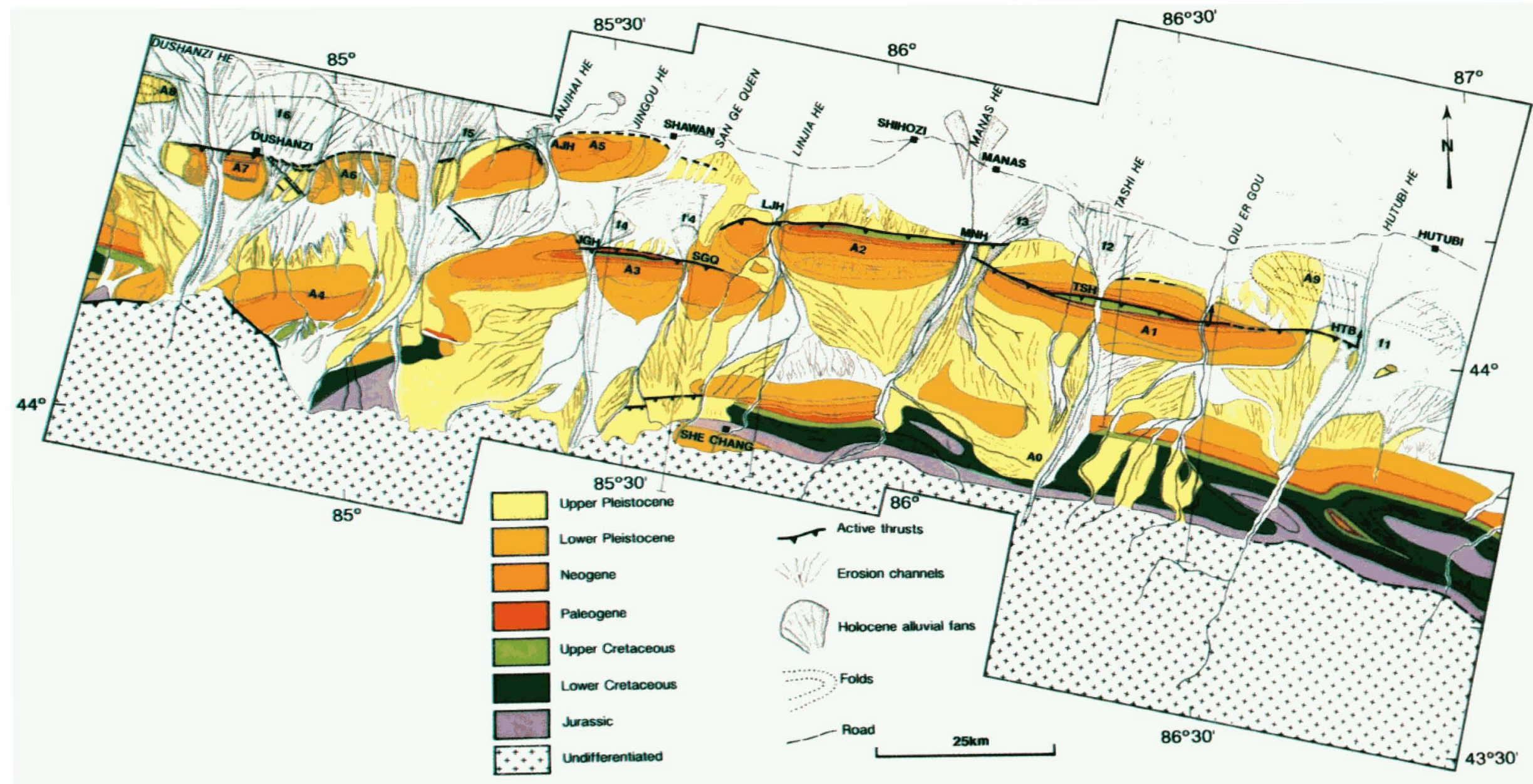

Plate 2b. Geological and tectonic interpretation. Note three prominent anticlinal rows. Active faulting was detected on SPOT images and studied in the field at Hutubi He (HTB), Tashi He (TSH), Manas He (MNH), Linjia He (LJH), San Ge Quen (SGQ), Jingou He (JGH), Anjihai He (AJH), and Dushanzi (DSZ) sites. Topographic profiles were levelled across recent fault scarps at all eight sites. Numbers refer to major anticlines (A) and to coeval alluvial fans (f). Arrows are horizontal projections of measured slickensides on exposed fault planes. 


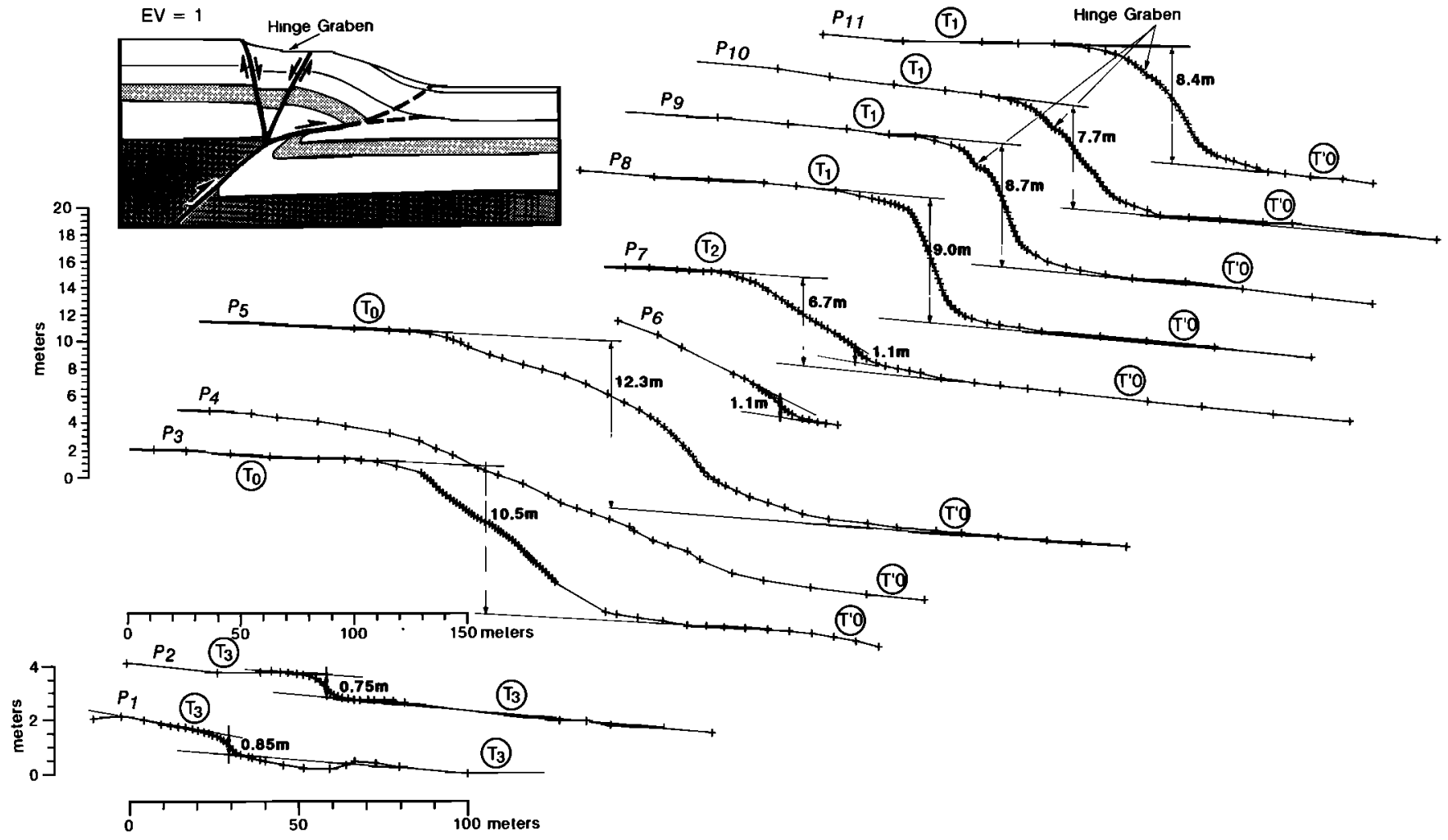

Fig. 7a. Profiles transverse to thrust scarp at site HTB.

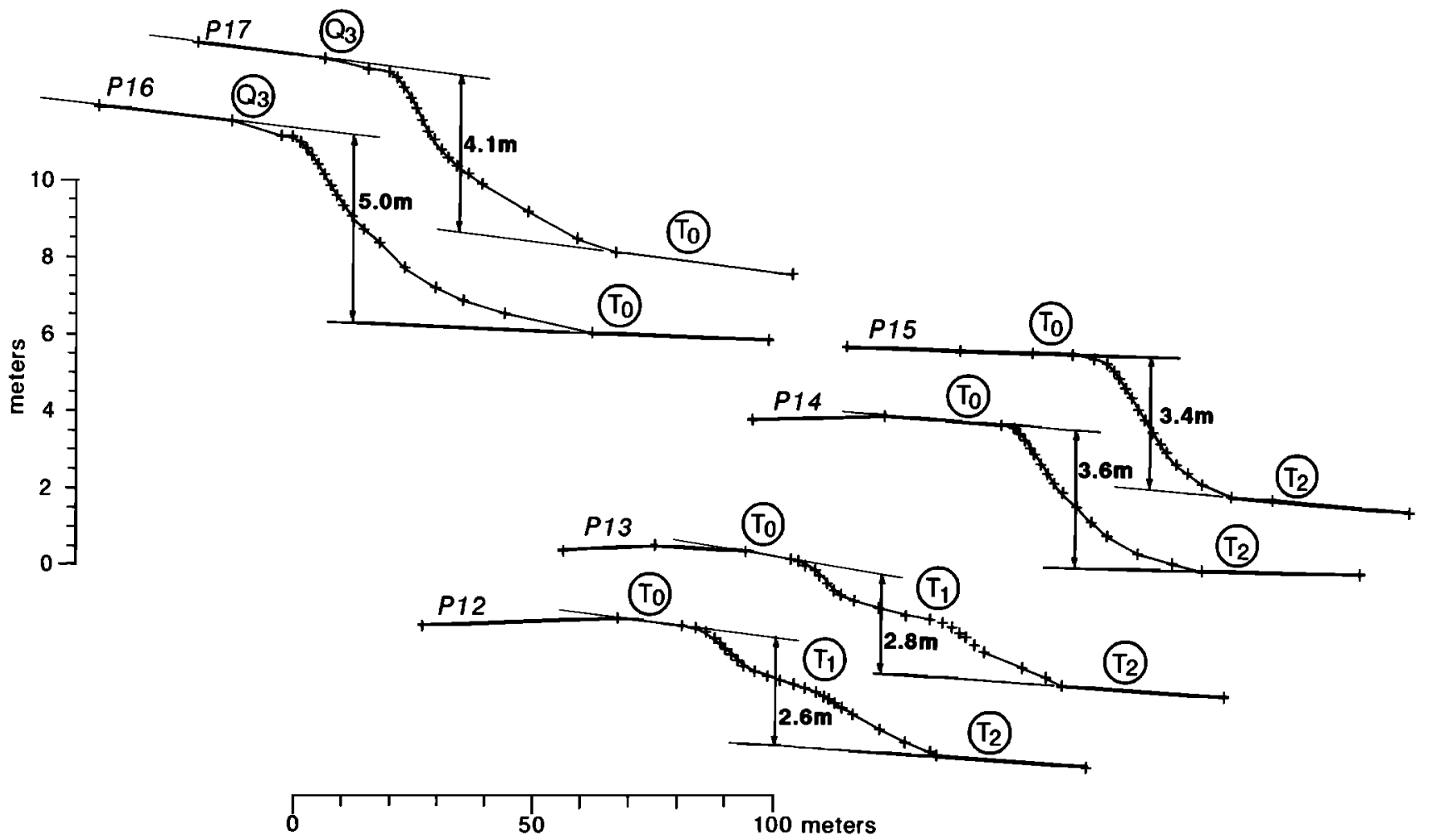

Fig. 7b. Profiles transverse to main terrace risers at same site. 


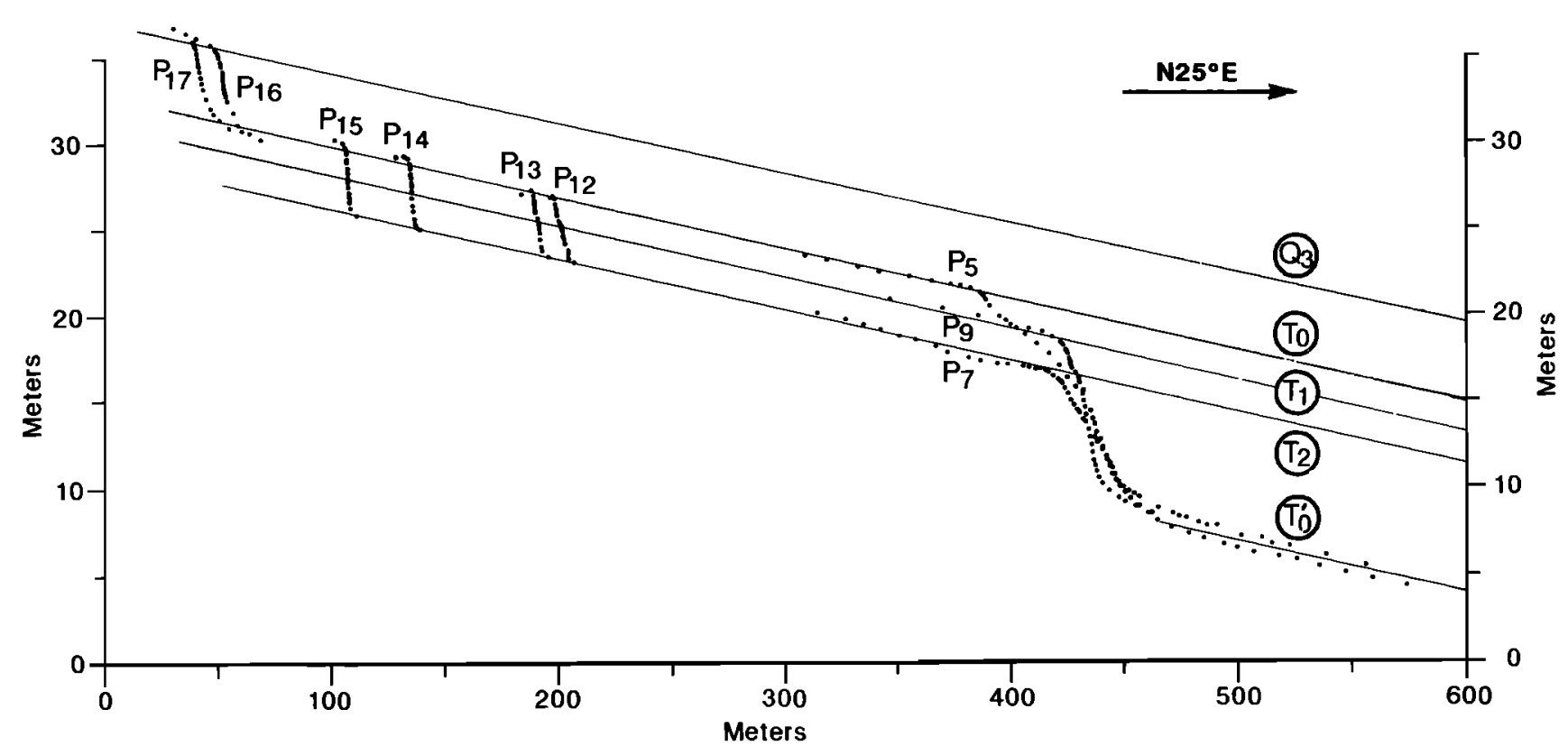

Fig. 7c. Projection on vertical plane striking $\mathrm{N} 25^{\circ} \mathrm{E}$ showing elevations of main fan terraces $(\mathrm{Q} 3, \mathrm{~T} 0, \mathrm{~T} 1, \mathrm{~T} 2)$ south of cumulative thrust scarp relative to more uniform fan surface north of scarp $\left(T^{\prime} 0\right)$. Dots are levelling points. Terrace heights and associated uncertainties are listed in Tables $\mathbf{1}$ and 2 .

mean height of the terrace riser between $\mathrm{Q} 3$ and $\mathrm{TC}$ $(4.5 \pm 0.4 \mathrm{~m}$ ), deduced from profiles P16 and P17 (Figures $7 b$ and $7 c$ and Table 2), to the vertical offset between T0 and $\mathrm{T}^{\prime} \mathrm{O}$. If the offset differences between T0 and T1 $(2.6 \pm 0.8 \mathrm{~m})$ and between $\mathrm{T} 1$ and $\mathrm{T} 2(1.8 \pm 1 \mathrm{~m})$ were taken to represent the cumulative throw of events comparable to that offsetting T3, three and two such events, respectively, would account for those differences. The offset difference between the two main terraces composing the upper surface of $\mathrm{fl}$ south of the thrust scarp (T0 to the east and $T 1$ to the west) accounts for the westward decrease of the height of that scarp (compare P8, P9 and P10, $\mathrm{P} 11$ in Figure $5 b$ ). That this decrease and the corresponding elevation difference are rather small over a length of $2 \mathrm{~km}$ along the scarp supports the inference we made that $\mathrm{fl}$ was emplaced as a coherent unit and abandoned in a relatively short time. Uniform wash on the upthrown block and deposition on the downthrown block might imply that the offset values above represent lower bounds of the real offsets. That profile slopes are almost the same and that visible erosion and deposition appear to be confined to a relatively narrow zone $(\approx 50 \mathrm{~m})$, compared to profile lengths, on either side of the scarp (Figures $7 b$ and $9 a$ ) suggest, however, that scarp height decrease related to such a process has been quite small. The total vertical throw on the Tugulu thrust since $\mathrm{fl}$ was emplaced and abandoned is thus at least $8.5 \pm 0.2 \mathrm{~m}$ and at most $11.1 \pm 0.6 \mathrm{~m}$. Taking the emplacement and rapid abandonment of $\mathrm{f1}$ to have occurred $10 \pm 2 \mathrm{ka}$, average Holocene vertical throw rates on that thrust are thus between $0.85 \pm 0.2 \mathrm{~mm} / \mathrm{yr}$ and $1.1 \pm 0.3 \mathrm{~mm} / \mathrm{yr}$ $(1.0 \pm 0.3 \mathrm{~mm} / \mathrm{yr}$ on average) at the surface.

\section{Tashi He Site (TSH)}

This site is located in the Tashi He narrows, within the core of anticline A1. Here the Tugulu thrust, which strikes $\mathrm{N} 90^{\circ}-100^{\circ} \mathrm{E}$ and dips $\approx 50^{\circ}-60^{\circ} \mathrm{S}$, reaches the surface between the upper Cretaceous and the Eocene (Plates $2 \mathrm{~b}$, and Figures $3 a$ and $8 b$ ). It has cut and offset high, abandoned terraces of the Tashi He along a prominent cumulative scarp, striking $N 85^{\circ} \mathrm{E}$ (Figures 8 and 9). On the right bank of the river, mainly three high inset terraces, T0, T1, and T2, are visible. Six profiles transverse either to the scarp or to terrace risers were levelled to constrain vertical offsets along the scarp and riser heights (Figures $8 b$, $10 a$, and 10b).

The uppermost terrace, T0, has been vertically offset $9.5 \pm 1.1 \mathrm{~m}$ by the thrust (P1, Figures $8 b$ and $10 a$, Table 1 ). The intermediate terrace, $T 1$, has been offset $7.8 \pm 1.0 \mathrm{~m} \mathrm{(P2}$, Figures $8 b$ and $10 a$, Table 1) and the lowest terrace, T2, $8 \pm 0.6 \mathrm{~m}$ (P3, Figures $8 b$ and $10 a$, Table 1). Being younger than T1, T2 should have recorded less vertical throw. Yet, in spite of the relatively high riser $(12.3 \pm 0.9 \mathrm{~m}$ on average on $\mathrm{P4}$ and P6, Table 2) between these two terraces, their offsets are undistinguishable within measurement uncertainties. Hence no movement appears to have occurred in the period between the abandonment of the two terraces. Given the height of the riser, this implies either a long recurrence time between successive seismic events or a fast incision by the river or a combination of both during that period at this site. Two events with amounts of throw comparable to that of the recent event at site HTB could account for the mean offset difference of the scarp across TO and T1-T2 (1.6 $\pm 1 \mathrm{~m}$, Table 1). The uppermost terrace T0 being continuous with fan $\mathrm{f} 2$ along the Tashi He valley (Plate 2 and Figure $8 a)$, we infer the total offset of T0 $(9.5 \pm 1.1 \mathrm{~m})$ to be a measure of the amount of Holocene throw on the Tugulu thrust in that valley. Given the age previously adopted for deposition of the fans $(10 \pm 2 \mathrm{ka})$, the corresponding vertical throw rate would be $0.95 \pm 0.3 \mathrm{~mm} / \mathrm{yr}$. That these numbers are close to those inferred at site HTB, along the same thrust, supports the inference made from SPOT images that $f 1$ and $f 2$ are coeval.

To assess quantitatively the state of degradation of the riser between $\mathrm{T0}$ and $\mathrm{T} 1$, we used a Gaussian model of scarp degradation [Avouac, 1991], which is adapted for scarps in unconsolidated conglomerates that are not eroded by transverse rills and have already lost their free face, if any. As in the analyses of Nash [1980], Hanks et al. [1984], and Hanks and Wallace [1985], the degradation process is assumed to be diffusion, by some form of downslope transfer of material with a rate proportional to topographic gradient. We also assume the usual finite initial slope geometry with planar regional topography [Hanks et al., 1984], with the initial scarp slope 
TABLE 1. Measurements of Fault Scarp Heights From Topographic Profiles on Terraces at Sites Described in Text

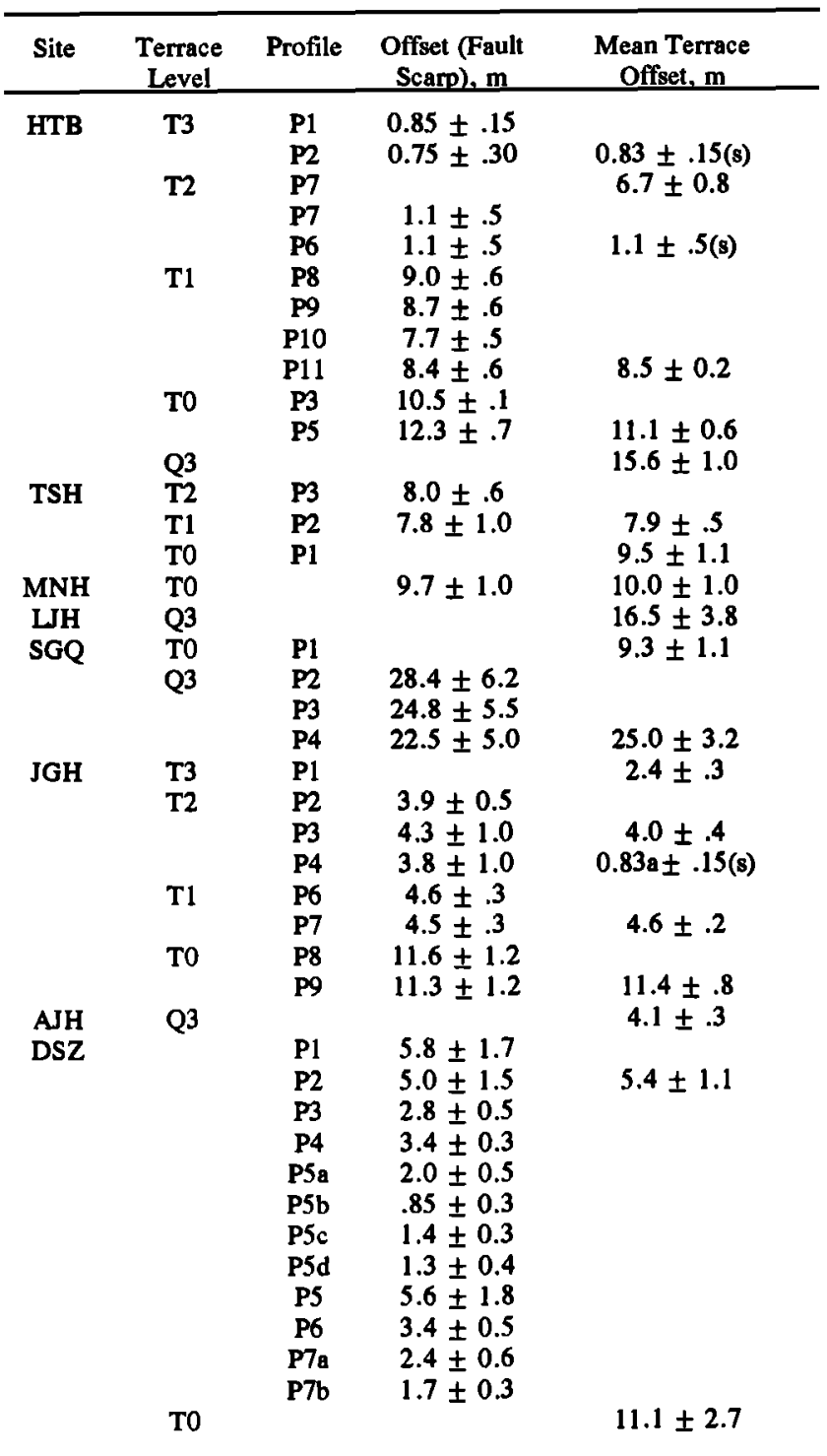

(s) at sites HTB and JGH refers to recent seismic offset. Uncertainties are assumed to be Gaussian and confidence intervals represent 1- $\sigma$ error bars. Mean values of vertical terrace offsets are weighted according to uncertainties ascribed to each measurement.

angle being the angle of repose of the material $\left(\approx 35^{\circ}\right)$. This condition generally holds soon after thrust earthquakes that often produce "fold scarps" at the surface [e.g., Tapponnier et al., 1990; Meyer et al., 1990a, b]. In the Gaussian model, the morphological evolution of the scarp shape is represented as the convolution of its initial shape by a Gaussian degradation function whose variance increases with time. A scarp degradation coefficient (expressed in square meters) is defined, equal to half the variance of the function that best approximates the measured scarp shape [Avouac, 1991, this issue]. This degradation coefficient (also called "erosion-age" by Tapponnier et al.[1990]) is the product of the age (in thousand years ago) by the diffusivity constant $k$ of linear diffusion models [e.g., Nash, 1980; Hanks et al., 1984; Avouac, 1991, this issue]. It is obtained by least squares fitting of synthetic profiles with the levelled profile (here P5, Figure $10 c$, left curve, bottom). That using a Gaussian model is valid can be seen by plotting together the synthetic and measured profiles slopes (Figure $10 c$, left
TABLE 2. Measurements of Heights of Abandoned Terrace Risers

\begin{tabular}{cccc}
\hline Site & Terrace Levels & Profile & Offset, m \\
\hline HTB & T0/T1 & P12 & $0.8 \pm .3$ \\
& T1/T2 & P12 & $1.5 \pm .4$ \\
& T0/T1 & P13 & $1.1 \pm .3$ \\
& T1/T2 & P13 & $1.7 \pm .4$ \\
& T0/T2 & P14 & $3.6 \pm .55$ \\
& T0/T2 & P15 & $3.4 \pm .3$ \\
& Q3/T0 & P16 & $5.0 \pm .6$ \\
& Q3/T0 & P17 & $4.1 \pm .5$ \\
TSH & T1/T2 & P6 & $13.1 \pm .4$ \\
& T0/T1 & P6 & $11.8 \pm .2$ \\
& T0/T1 & P6 & $13.8 \pm .5$ \\
& T1/T2 & P6 & $11.5 \pm .3$ \\
JGH & T2/T3 & P10 & $5.6 \pm .35$ \\
& T2/T3 & P11 & $6.7 \pm .4$ \\
& T1/T2 & P12 & $5.5 \pm .4$ \\
& T1/T2 & P13 & $5.1 \pm .5$ \\
& T1/T2 & P14 & $6.8 \pm .4$ \\
& T1/T2 & P15 & $7.1 \pm .8$ \\
& T0/T1 & P16 & $5.1 \pm .7$ \\
& T0/T1 & P17 & $4.3 \pm .6$ \\
\hline
\end{tabular}

Uncertainties as in Table 1.

curve, top). The accuracy with which the degradation coefficient is defined may be seen on the plot representing the variation, as a function of that coefficient, of the standard deviation of the misfits between synthetic and measured profiles, (Figure $10 c$, right). A sharp minimum defines a well-constrained coefficient. The confidence interval of this coefficient is assumed to be that corresponding to standard deviations less than $5 \mathrm{~cm}$ greater than the minimum (Figure 10c, right) [Avouac, this issue]. For P5, the best fitting synthetic profile yields a degradation coefficient $\tau=36 \pm 10 \mathrm{~m}^{2}$ with a rather well-defined standard deviation minimum of $0.33 \mathrm{~m}$. The riser top has a sharper curvature than predicted by Gaussian degradation. This implies that nonlinear processes [e.g., Andrews and Bucknam, 1987], such as nondiffusive slope wash, which are all the more active when a scarp is high, may have contributed to degradation. In Gansu province, on the northern piedmont of the Qilian Shan, a semiarid zone drier than the northern piedmont of the Dzungarian Tien Shan, we obtained a late Holocene mass diffusivity of $3.3 \pm 1.7 \mathrm{~m}^{2} / \mathrm{ka}$ from modelling the Gaussian degradation of the thrust scarp inferred to correspond to the 180 A.D., $M=7.5$, Luo Tuo Chen earthquake [Tapponnier et al., 1990]. Note that taking a mass diffusivity value greater than $3.3 \pm 1.7 \mathrm{~m}^{2} / \mathrm{ka}$ would yield less than $11 \pm 9 \mathrm{ka}$ for the age of abandonment of the high terrace $\mathrm{T} 1$ in the Tashi He valley, a value consistent with our inference that $\mathrm{TO}$ and $\mathrm{T} 1$ are early Holocene terraces.

\section{Manas He Site (MNH)}

The Manas River crosses the principal fold row of the piedmont in a 4-km-wide gap located between the slightly offset periclines of A1 and A2. Within this gap, the river has dug two principal channels, separated by a tongue capped by a loesscovered terrace (Q3), (Plate 2). The high terrace T0 that is continuous with fan $\mathrm{B}$ penetrates far into the two channels on either side of that tongue. At present, the river flows in the western channel. The eastern one, now abandoned, only collects the waters of a small tributary. Both $\mathrm{TO}$ and $\mathrm{Q} 3$ are cut by two prominent scarps (Figures $11 a$ and $11 b$ ), about $2 \mathrm{~km}$ apart, that mark the overlapping extremities of the ramp thrusts along A1 and A2 (Plate 3). 


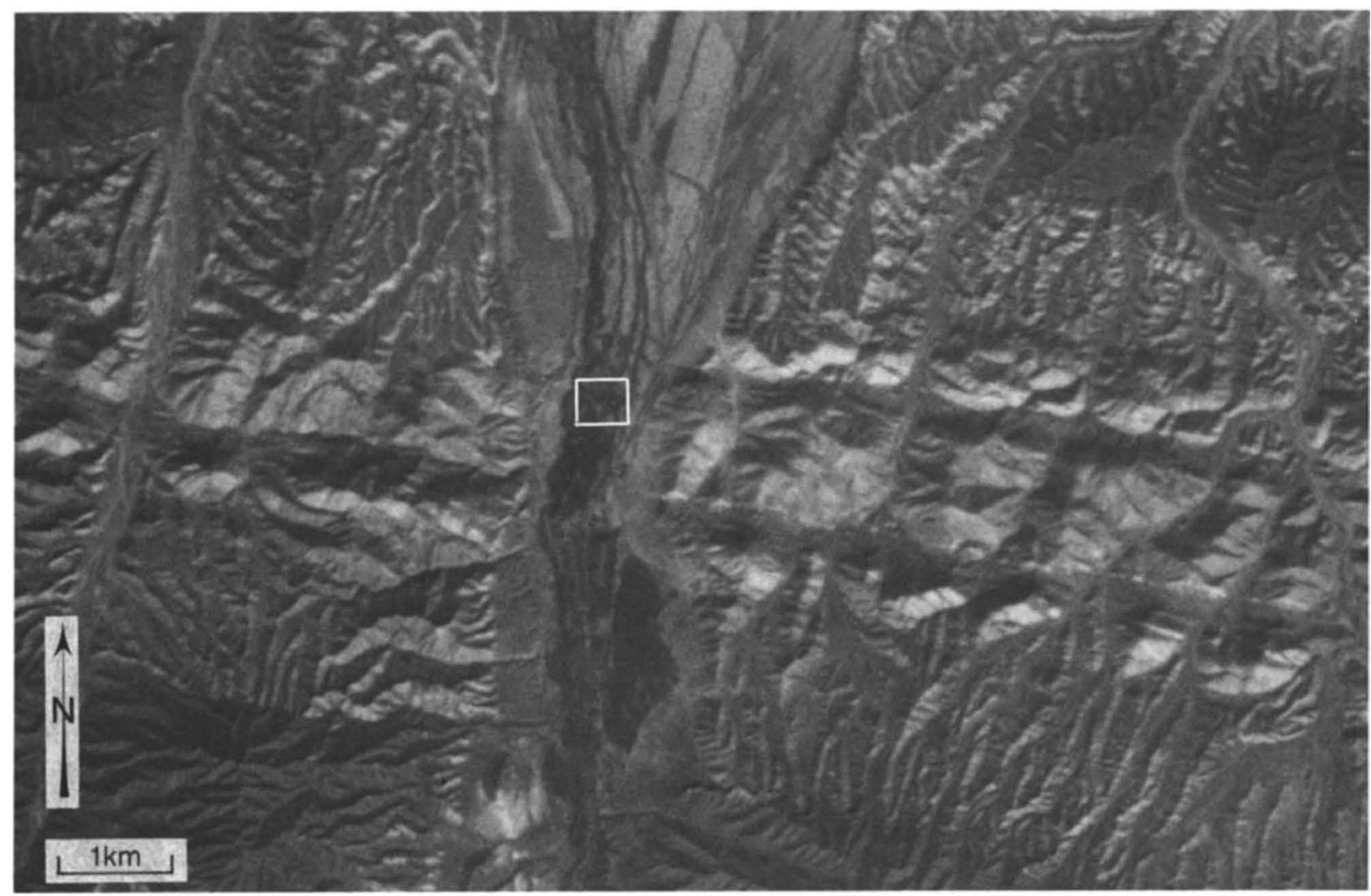

Fig. 8a. SPOT view of thrust scarp across Tashi He narrows terraces (site TSH, Plate 2b; scene KJ 215-261, August 4 1986). Box is area of field measurements.

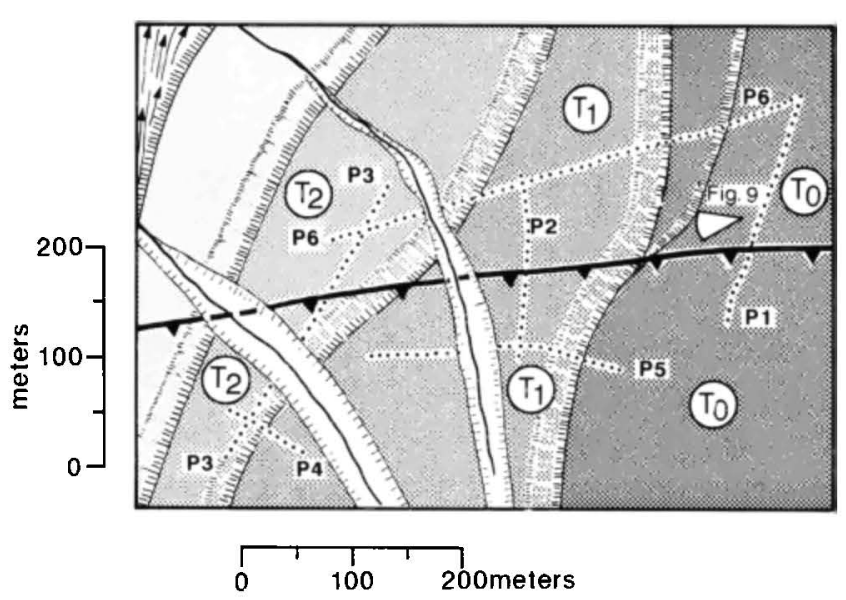

Fig. $8 b$. Sketch map of box in Figure $8 a$ showing main terraces levels (T0 to T2) and location of levelling profiles (P1 to P6).

Active faulting at this site is thus more complex than at either of the previous sites, where a unique thrust trace is found. West of the Q3 tongue, however, the height of the northern scarp is much greater than that of the southern scarp. Near the foot of the T0-Q3 riser for instance, the height of the southern scarp is only about $3 \mathrm{~m}$ (Figure 11a). Moreover, this height appears to decrease westwards. Thus, in the vicinity of the present river channel, most of the offset of TO is at the northern scarp (Figure $11 b$ ). Since the height of the northern scarp decreases along strike towards the east, we infer the situation to be opposite in the abandoned channel, east of the $Q 3$ tongue. Access to this channel was prohibited, but we suspect the southern scarp to be the principal one there. Such a geometry suggests that the sum of the vertical throws on NS sections across both thrusts remains roughly constant in the overlap zone, as slip is progressively transferred from one thrust plane to the next, probably along a branch line at depth.

Despite the existence of man-made buildings and irrigated fields on top of TO near the northern scarp, we could level one sufficiently long profile across that scarp (Figure 11c), a few tens of meters west of the road and a few hundred meters east of the riser forming the steep limit between TO and the present valley floor (Plate 2). On that profile, the scarp height is at least $9 \mathrm{~m}$, and probably very close to $10 \mathrm{~m}(9.7 \mathrm{~m}$ on Figure $11 \mathrm{c})$. The surface of TO south of the scarp has been degraded by digging and cultivation, but the height could not have been greater than about $11 \mathrm{~m}$. Thus, although the profile does not permit constraint of the upper bound of the scarp height with precision, we take the value of $10 \pm 1 \mathrm{~m}$ to be that most consistent with our measurements (Table 1). Given the age inferred for $\mathrm{B} 3(10 \pm 2 \mathrm{ka})$, this cumulative throw implies an average Holocene throw rate of $1 \pm 0.3 \mathrm{~mm} / \mathrm{yr}$ at this site, comparable to those found at the previous sites.

\section{Linjia He Site (LJH)}

The Linjia He narrows cut the western extremity of anticline A2 (Plate 2). On the left bank of the river, north of the dam (Figure 12), shallow north dipping Quaternary fanglomerates (Q3) mantled by a relatively thick loess layer unconformably cap the steeply north dipping Neogene beds of the north limb of the 


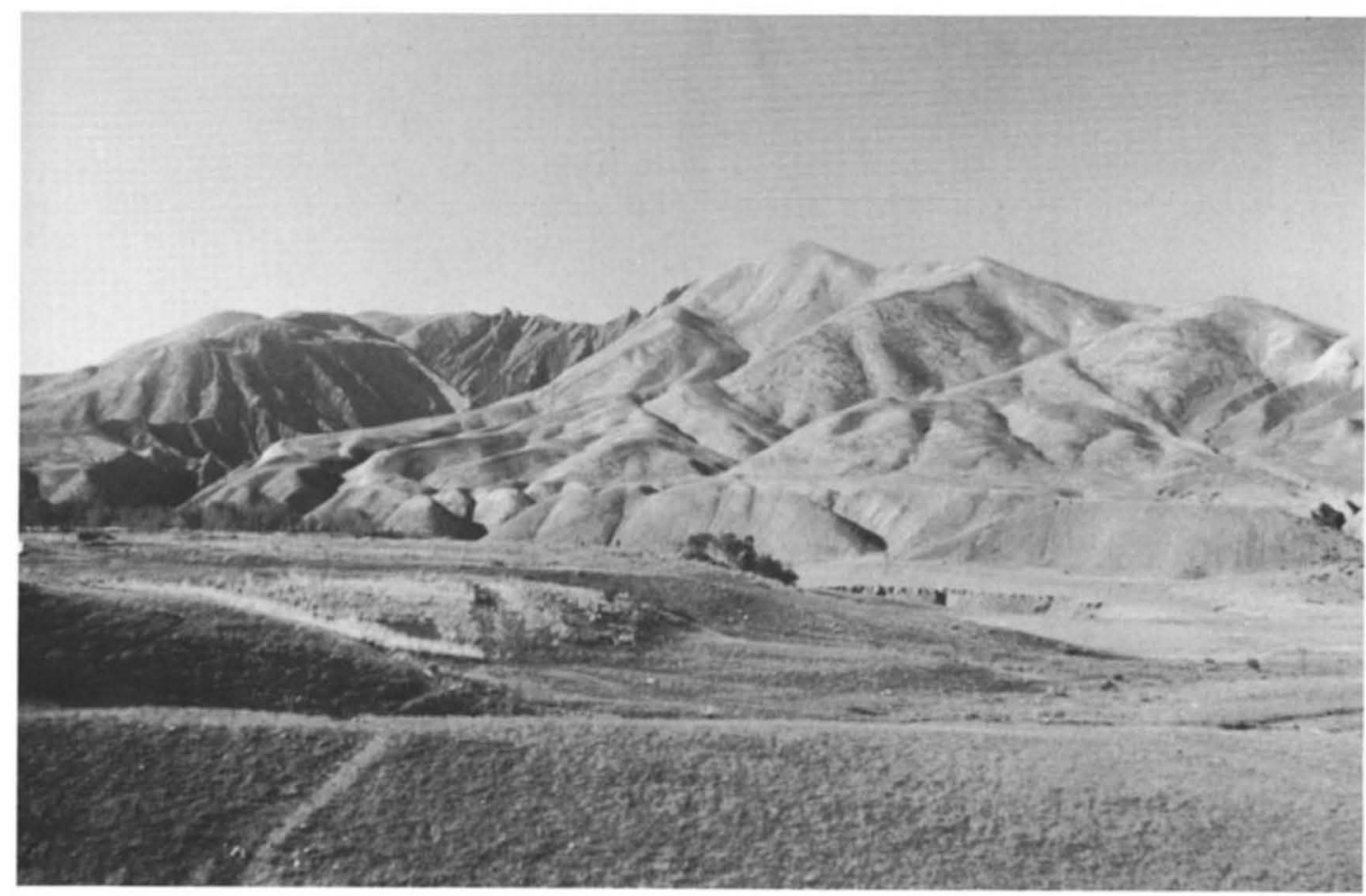

Fig. 9. West looking view of thrust scarp offsetting terrace T1 at site TSH. Note south dipping Eocene red beds in overthrust hanging wall (background left).

anticline (Plate 3). The relatively flat part of the top surface of the fanglomerates that has escaped incision is uniformly tilted northwards, by about $5^{\circ}$. The active thrust trace follows the front of the gentle fold limb thus formed (Plate 2 and Figures $12,13 a$ and $13 b$, inset). Cumulative throw along the thrust has built a clear, faceted scarp (Figures 12,13a and 13b). Regional slopes being markedly differenly above and below the scarp, the cumulative vertical offset of the Q3 fanglomerates top surface can only be roughly determined. From profile P (Figure $13 b$ ), that offset is estimated to be $16.5 \pm 3.8 \mathrm{~m}$ (Table 1 ) by taking the mean value of the minimum and maximum offsets measured at the scarp base and top, respectively. The fact that the top surface of the Q3 fanglomerates, which are not much different from the Holocene fanglomerates from a sedimentological point of view, is tilted about $5^{\circ} \mathrm{N}$ (a slope about 5 times greater than the average regional slope of the piedmont $\left(1.1 \pm 0.1^{\circ} \mathrm{N}\right)$ and than the slopes of early Holocene surfaces TO at sites HTB and TSH (about $1^{\circ} \mathrm{N}$ )) corroborates the inference that these fanglomerates are older than Holocene and that their surface tilt is due to folding. Evidence of smaller, more recent offsets may have been obscured by grave digging near the base of the scarp and by dam construction along strike in the valley.

\section{San Ge Quen Site (SGQ)}

At this site, near the eastern end of anticline A3, a prominent north facing thrust scarp offsets thicky loess blanketed late Quaternary fanglomerates similar to those at site $\mathrm{LJH}(\mathrm{Q} 3)$, as well as the highest inset fluvial terrace in the San Ge Quen valley. This high terrace appears to be continuous with fan $f^{\prime} 4$, analogous to $\mathrm{f4}$, built by the San Ge Quen river north of A3 (Plate 2 and Figure 14 and 15). Four profiles transverse to the scarp (Figure 16) show that the $5-6^{\circ}$ north sloping, probably folded, top surface of the $Q 3$ conglomerates has recorded $25 \pm 3.2 \mathrm{~m}$ of minimum vertical throw while the younger inset terrace has been offset $9.3 \pm 1.1 \mathrm{~m}$ by the thrust (Table 1). This latter offset, which is comparable to the offsets of features inferred from SPOT images to be coeval at previous sites, implies a Holocene throw rate of $0.9 \pm 0.3 \mathrm{~mm} / \mathrm{yr}$ on the thrust.

\section{Jingou Site (JGH)}

Farther west along $\mathbf{A 3}$, on the left bank of the river at the outlet of the Jingou He narrows, the thrust cuts across the grass covered surface of the head of fan $f 4$ for a length of nearly $2 \mathrm{~km}$ (Plate 2 and Figure 17). The cumulative thrust scarp, which strikes $\mathrm{N} 95^{\circ} \mathrm{E}$, is not much degraded by rills and gullies (Figure 18a). The entrenched Jin Gou river now flows $35-40 \mathrm{~m}$ below the fanhead top surface north of the scarp and is flanked by prominent, abandoned inset terraces (Figures 17 and 18a). The scarp is nearly perpendicular to the risers between the four principal terrace levels (from top to bottom: T0,T1,T2, and T3, Figures $17,18 b, 18 c$, and 19 , inset). The cumulative height of the scarp is less across the lowermost, younger levels. Near the base or the top of the scarp in these levels we found fresh seismic scarplets (Figure 18d), comparable to those seen at site HTB. As at that site, these scarplets are still outlined by disrupted turf, rodent holes, and exhumed pebbles, a suggestion that they may be less than a few hundred years old (Figure 18d). In the uppermost terraces, such recent seismic breaks are indistinct and probably lie within the pebbly slope of the higher and steeper cumulative thrust scarp.

Seventeen profiles were levelled across the thrust scarp and the terrace risers (Figures 19 and 20). On the narrow remnant strip of T3, about 15 above the river floodplain, the vertical offset of the terrace surface across the thrust scarp is only $2.4 \pm 0.3 \mathrm{~m}$ (P1, Figure 19, Table 1). On T2, it is $4.0 \pm 0.4 \mathrm{~m}$ on average, about $1.6 \mathrm{~m}$ higher than on T3. Here, the thrust trace splays into two branches, which results in a composite scarp with evidence of mutiple faulting events (P2, P3 and P4, Figure 19, Table 1). On profiles P4 and P5, the clearest, recent seismic scarplet is at the base or slightly in front of the cumulative scarp 
(Figure 18d), while it is near the top of that scarp on profiles P2 and P3 (Figures 19 and 20c). The vertical offsets measured across these seismic scarplets are $0.83 \pm 0.15 \mathrm{~m}$ on $\mathrm{P} 2$ and $\mathrm{P3}$, and $0.89 \pm 0.15 \mathrm{~m}$ on P4 and P5 (Figures 19 and $20 \mathrm{c}$ and Table 1). These values are nearly identical to those measured at site HTB (Table 1).

The vertical offset of terrace $\mathrm{T} 1$ across the cumulative thrust scarp is $4.6 \pm 0.2 \mathrm{~m}$, about $0.6 \mathrm{~m}$ higher than that of terrace $\mathrm{T} 2$ (P6 and P7, Figure 19 and Table 1). That of the uppermost terrace level, T0, is $11.4 \pm 0.8 \mathrm{~m}$ (P8 and P9, Figure 19 and Table 1). This is the largest vertical offset at this site. It is about $6.8 \mathrm{~m}$ higher than that of the next terrace level below (T1). On both T0 and T1, a clear hinge graben is visible near the top of the cumulative scarp (P6-9, Figure 19). It must be noted that in the Hutubi and Jingou valleys, the shapes of profiles levelled across the cumulative scarps where they are highest are closely comparable (Figures 19 and $7 a$ ). At both sites, the appearance

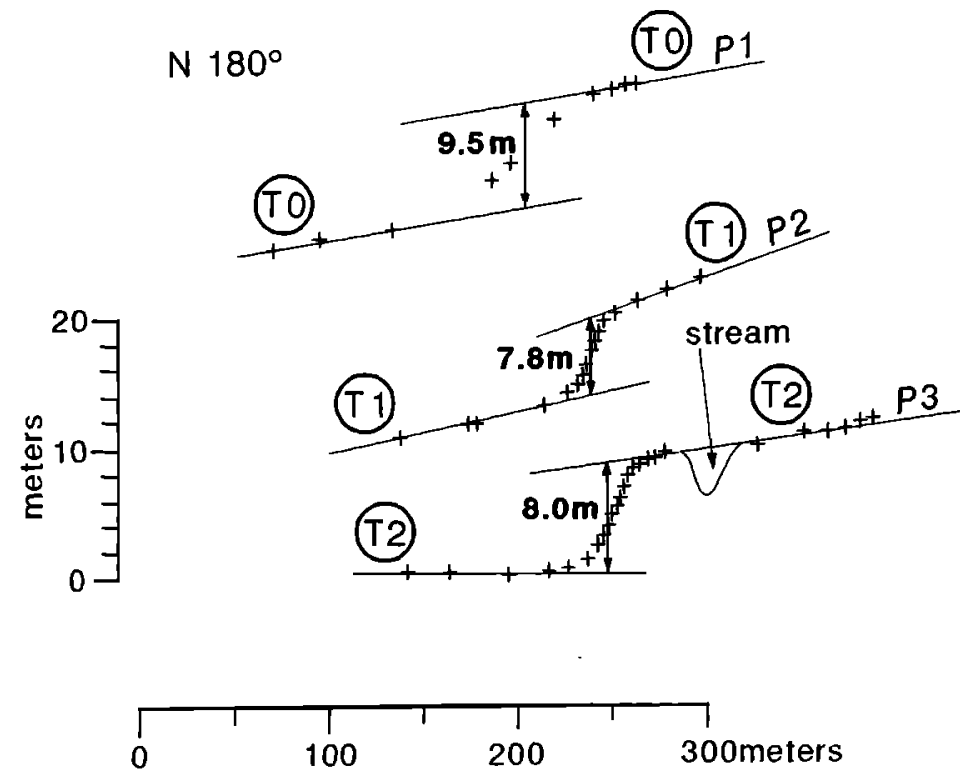

Fig. 10a. N-S projection of profiles P1 to P3 transverse to scarp at site TSH. of a hinge graben with increasing cumulative offset probably reflects the development of a fault bend fold as both the emerging thrust plane and the toe of the hanging wall tend to flatten parallel to the topographic surface of the footwall (Figure $7 a$, inset).

The surface of the highest terrace level TO is the top surface of fan $\mathrm{f4}$, which we have inferred from the SPOT images to be coeval with similar fans at sites HTB, TSH, and SGQ and to have formed $10 \pm 29 \mathrm{ka}$. The vertical offset of T0 $(11.4 \pm 0.8 \mathrm{~m})$ thus implies a vertical Holocene throw rate of $1.1 \pm 0.3 \mathrm{~mm} / \mathrm{yr}$, similar to those inferred at the other sites.

The vertical offset of T3 and the differences of cumulative vertical offsets between $\mathrm{T} 3$ and $\mathrm{T} 2, \mathrm{~T} 2$ and $\mathrm{T} 1$, and $\mathrm{T} 1$ and $\mathrm{T} 0$ $(2.4,1.6,0.6$, and $6.8 \mathrm{~m}$, respectively) may be interpreted to be the sum of respectively about $3,2,1$, and 8 offset quanta roughly equal to that of the most recent seismic event $(\approx 0.8 \mathrm{~m})$. This would imply that the Jingou thrust has had a regular behavior, with characteristic earthquakes producing similar amounts of surface throw throughout the Holocene. The existence of such earthquakes has been documented on several seismogenic faults, particularly in western North America [e.g., Schwartz and Coppersmith, 1984].

In order to better constrain the chronology of thrusting across the Jingou He terraces, the shapes of the T2/T3 and T1/T2 terrace risers (profiles P10 and P11, Figure 20a, and profiles P12-15, Figure 20b, respectively) were modelled to determine their state of degradation, following the approach used at site TSH. Unfortunately, profiles P16 and P17 do not permit modelling of the degradation of the T1/T0 riser because active stream erosion has rejuvenated the base of this riser (Figure 19).

Across the T2/T3 riser, profile P10 yields a well-defined degradation coefficient of $15.8 \pm 5 \mathrm{~m}^{2}$, with a minimum standard deviation of $0.07 \mathrm{~m}$ (Figure 20a, top and Table 3). Profile P11 cuts a second-order riser (only about $1 \mathrm{~m}$ high) merging with the base of the main T2/T3 riser (Figure 19, inset). The composite nature of the riser is clear on the profile-slope plot (Figure 20a), which departs from the symmetrical shape typical of degradation of a single scarp. By modelling only the top part of the riser, a degradation coefficient value of $14.8 \pm 5 \mathrm{~m}^{2}$ with a minimum standard deviation of $0.1 \mathrm{~m}$ (close to that derived from P10) is obtained (Figure 20a and Table 3). The average value of this

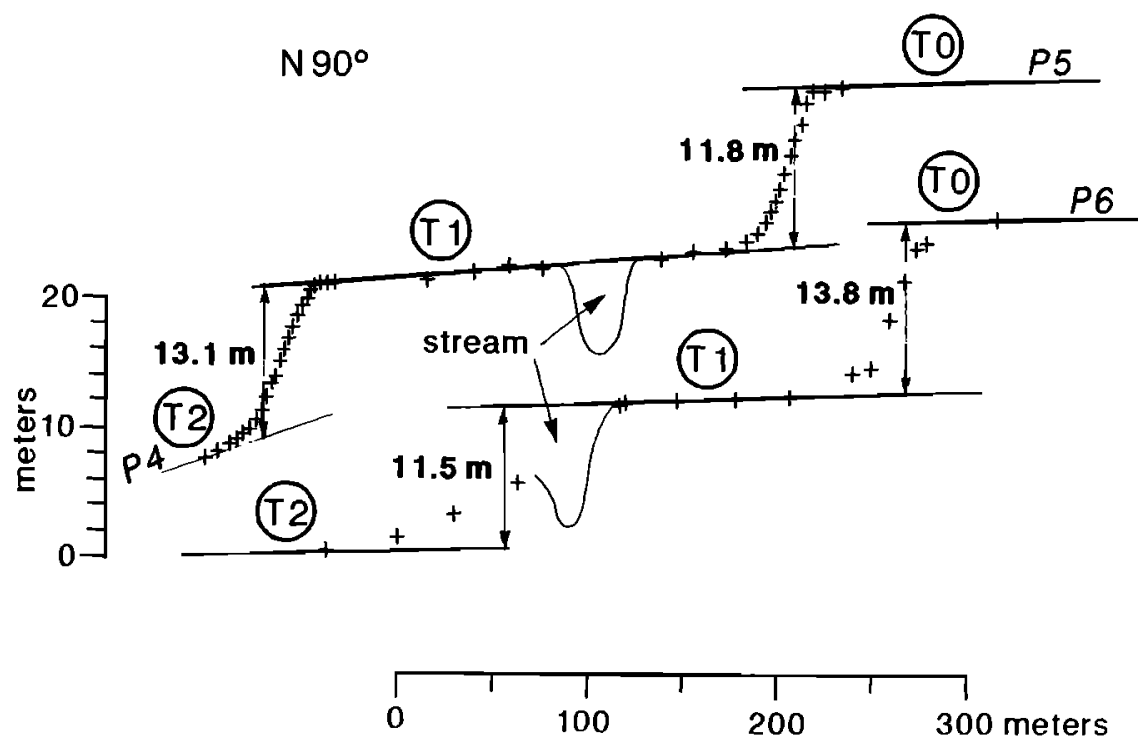

Fig. 10b. E-W projection of profiles P4 to P6 transverse to terrace risers at same site. 

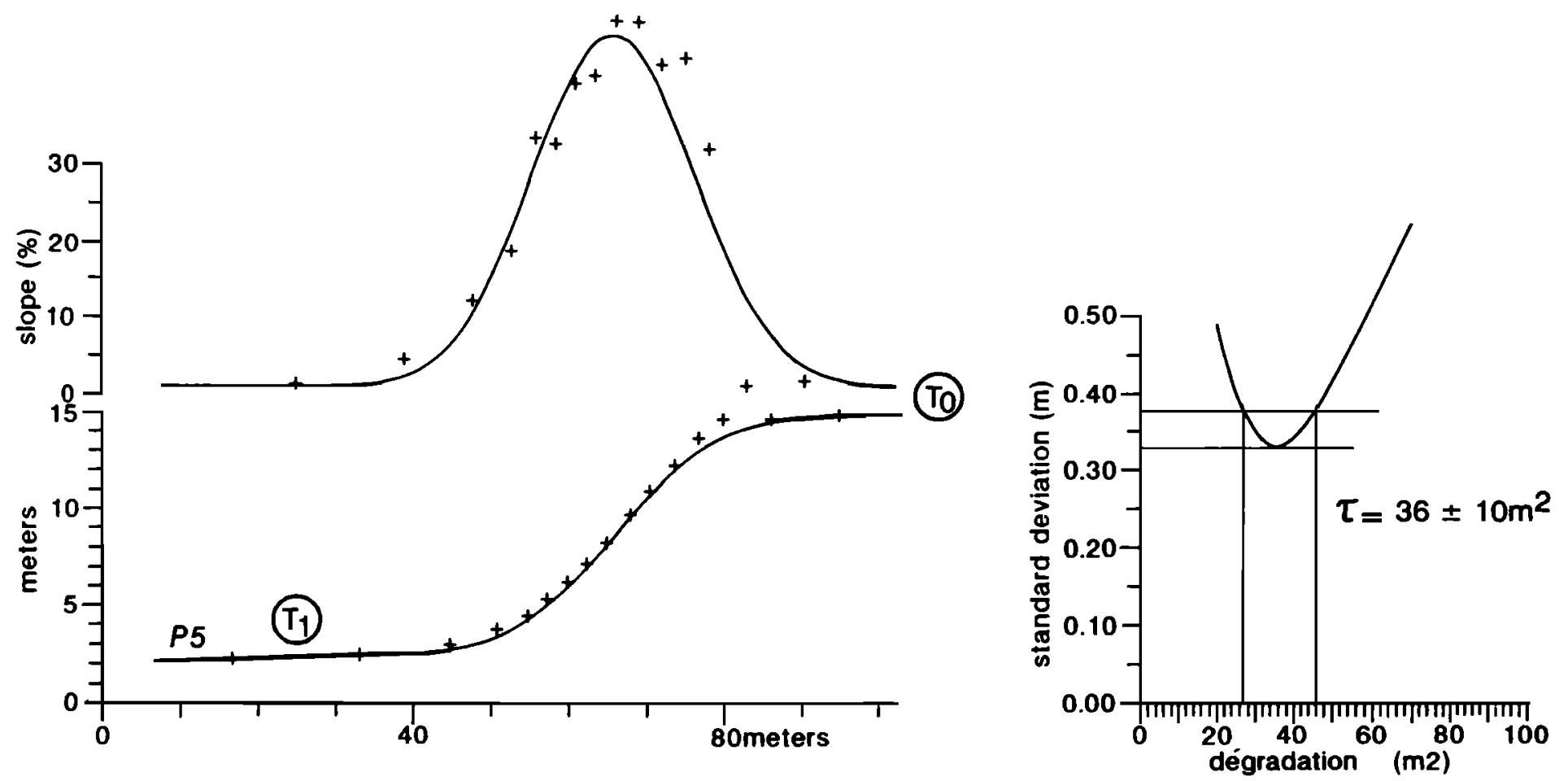

Fig. 10c. Morphological analysis of profile P5 across T0-T1 terrace riser. (Bottom left) Solid line is synthetic profile providing best fit to measurements (crosses). Fit between synthetic and measured slopes is shown on top. (Right) Standard deviation of vertical misfits between synthetic profile and measurements plotted as a function of degradation coefficient. The $5 \mathrm{~cm}$ uncertainty on vertical measurements yields $10 \mathrm{~m}^{2}$ uncertainty on degradation coefficient. Parameters and results are listed in Table 3. 


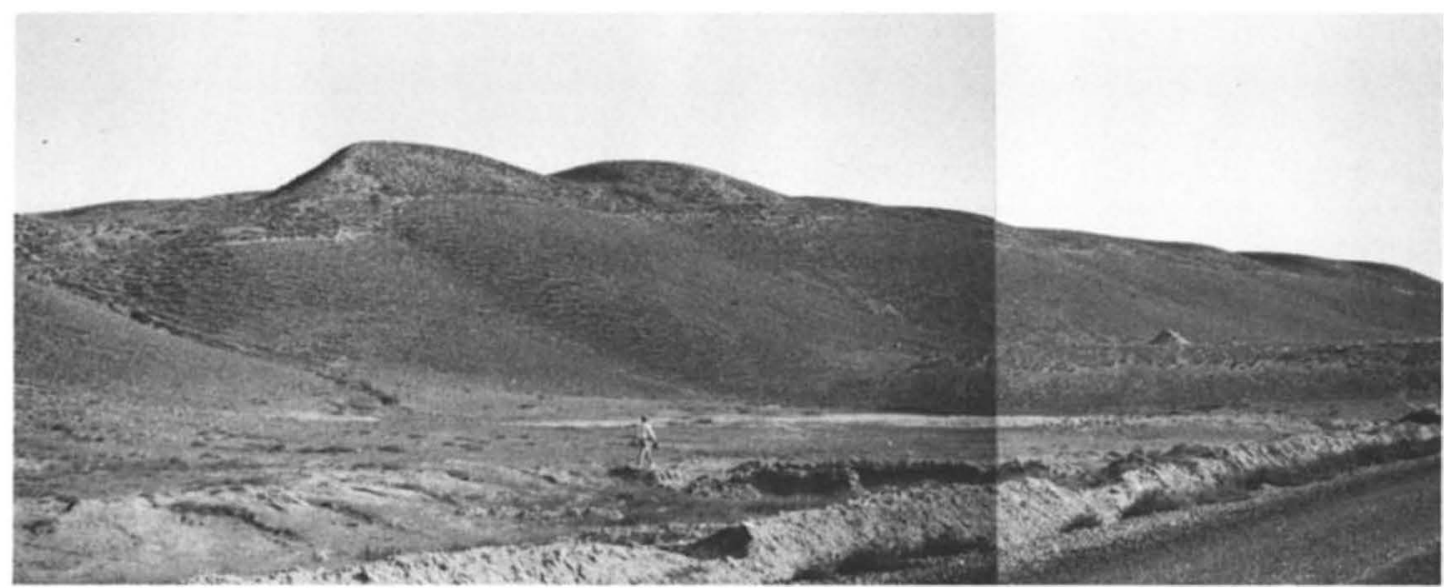

Fig. 1la. Southeast looking view of southern thrust scarp at Manas He site (MNH in Plate $2 b$ ). Scarp height under grave is about $3 \mathrm{~m}$.

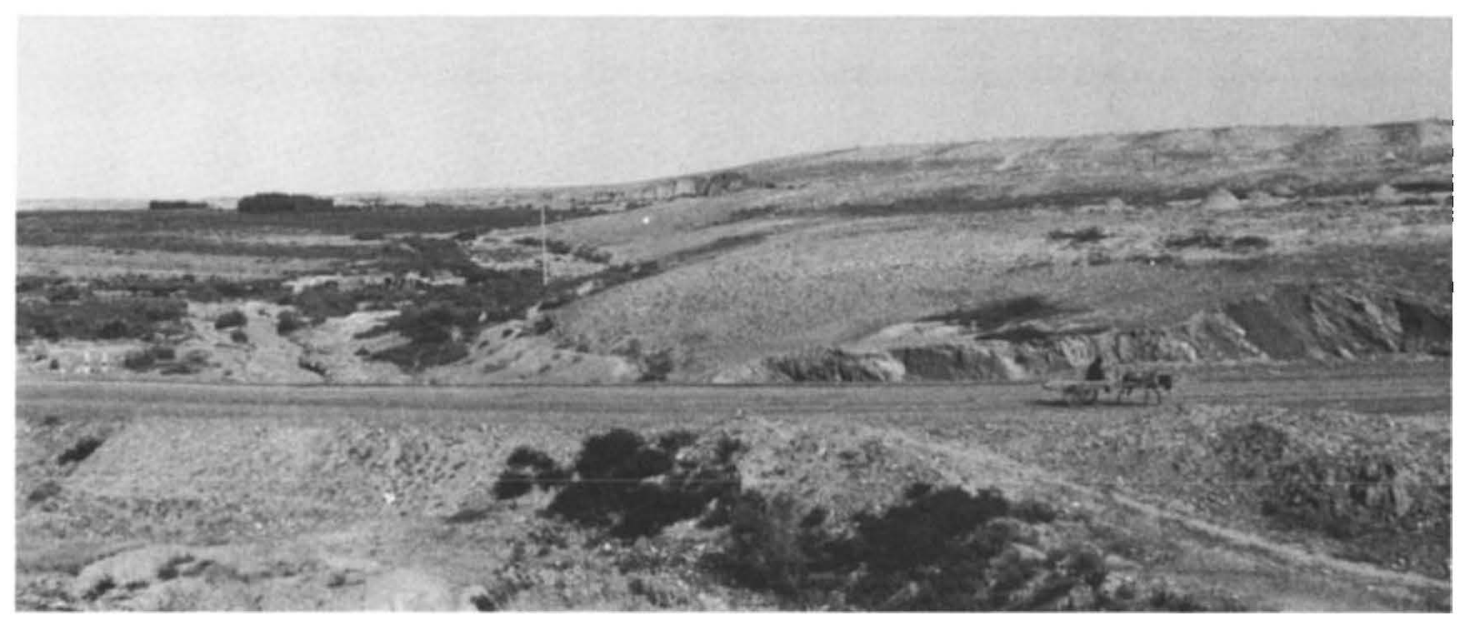

Fig. 11b. East looking view of northern thrust scarp on terrace T0 at site MNH.

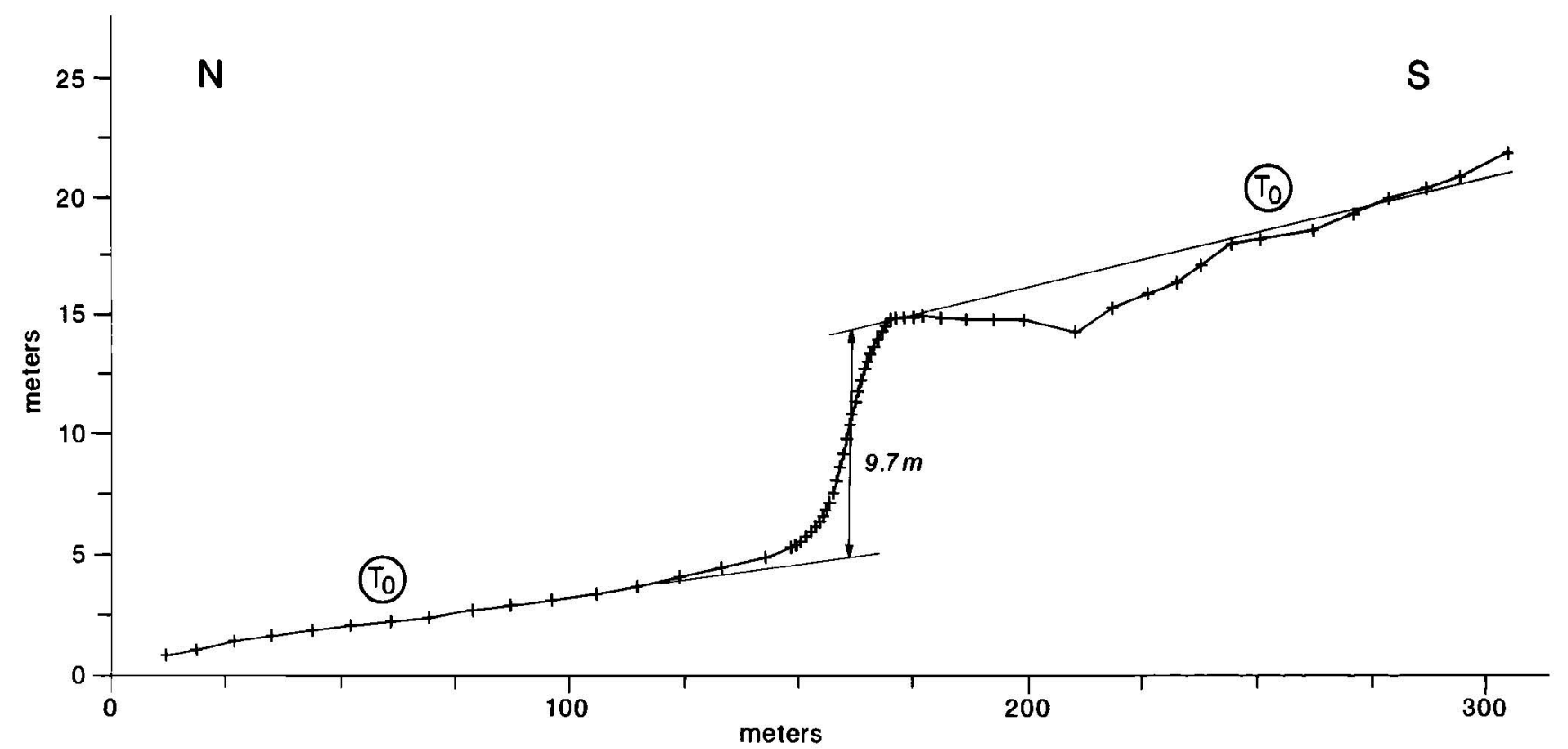

Fig. 11c. Topographic profile across MNH northern thrust scarp, west of road in Figure $11 b$. 


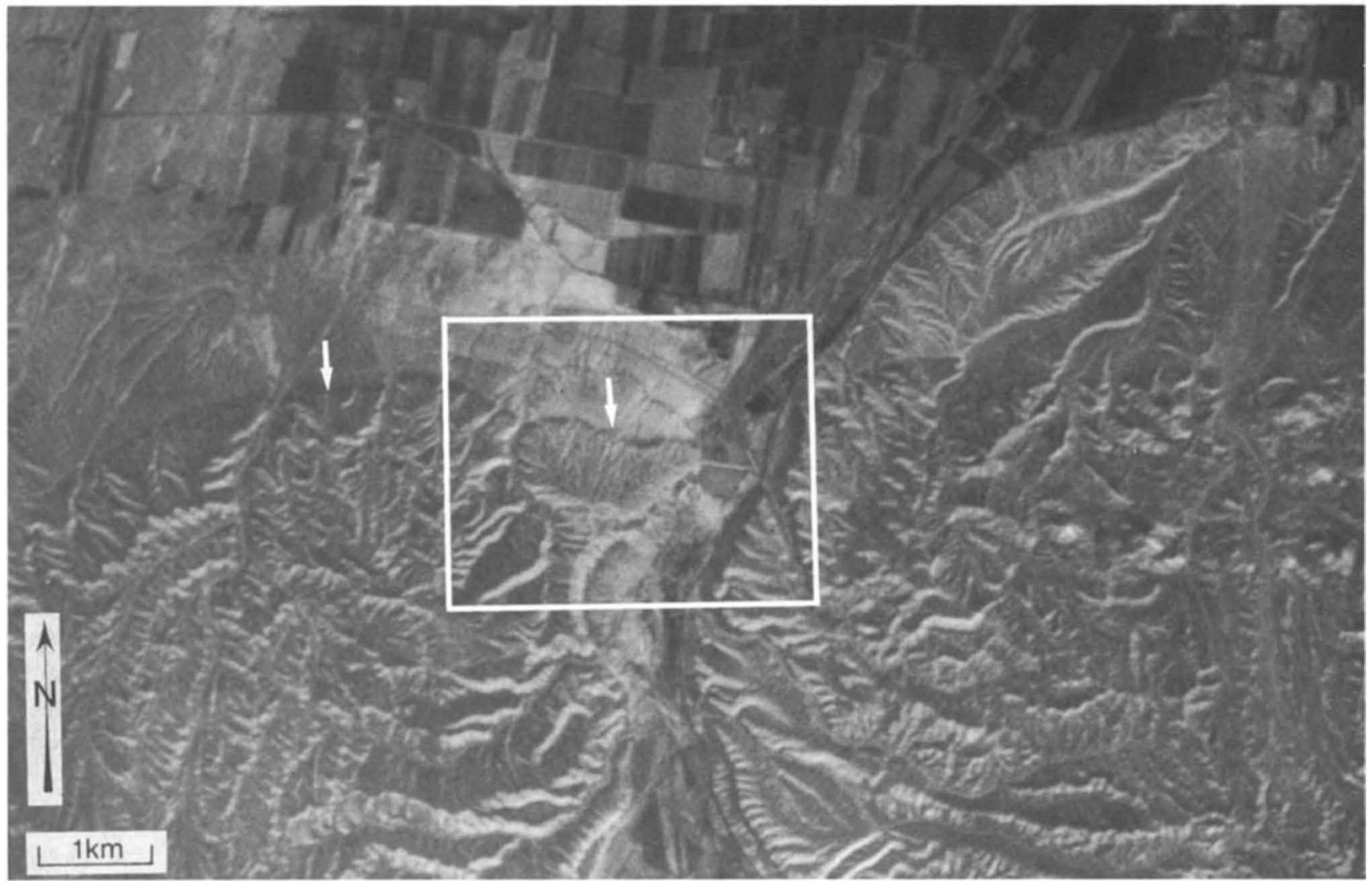

Fig. 12. SPOT view of thrust scarp west of Linjia He (site LJH, Plate $2 b$; scene KJ 215-261, August 4, 1986). Arrows point to scarp. Box is area of field measurements.

degradation coefficient $\left(15.2 \pm 3 \mathrm{~m}^{2}\right.$, Table 3$)$ constrains the age of abandonment of $\mathrm{T} 3$, and hence of its subsequent tectonic offset by the thrust.

Profiles P12 to P15 cross the T1/T2 riser on both sides of the thrust scarp (Figures 19 and 21). Although the riser is about $1 \mathrm{~m}$ higher south of the thrust, modelling of these four profiles yields similar degradation coefficients, between $18 \pm 5$ and $24 \pm 8 \mathrm{~m}^{2}$, with standard deviation minima between 0.1 and $0.2 \mathrm{~m}$ (Figure $20 b$ and Table 3 ). The average value, $19.5 \pm 3 \mathrm{~m}^{2}$, is greater than that obtained for the riser between T2 and T3, which is consistent with $\mathrm{T} 2$, which lies above T3, having been abandoned earlier than T3.

Finally, we tried to characterize the state of degradation of the seismic scarplets on profiles P3 to P5 (Figures 19 and 20c). The modelling is feasible, which supports the inference that the scarplets formed in a single event (Figure 20c). That the degradation coefficients obtained are small $(2.3+4 /-2,3.0+8 /$ 2.5, and $4.5+8.5 /-1.5 \mathrm{~m}^{2}$, Figure $20 c$ and Table 3) corroborates the evidence that the scarplets are recent. Note also that the scarp slope plot of profile P3 reveals a sharp slope break at the base of the cumulative scarp that is distinct from the scarplet near its top (arrows 1 and 2, respectively, Figure 20c). This suggests that the scarplet located in front of the cumulati scarp on profiles P4 and P5 is still present, though less discernable, at the base of that scarp on profile P3. The degradation coefficient values are too small and too imprecise to permit further analysis or draw additional inferences.

\section{Anjihai He Site (AJH)}

The north dipping bedding-parallel thrust exposed within the Pliocene of the north limb of anticline A5, on the left bank of the
Anjihai He valley, about $200 \mathrm{~m}$ south of the front of the anticline (AJH, Plate 2), is clearly an active feature. Movement on this thrust has offset the 4-m-thick late Quaternary (Q3) terrace (a layer of rounded grey pebbles with sand intercalations) that caps unconformably the Neogene beds 10 to $20 \mathrm{~m}$ above the valley floor and dips aoout $5^{\circ}$ towards the north (Plate 3 and Figure 21). A south facing scarp marks the thrust trace at the surface. Profiles along the edge of the terrace surface and along some of the Pliocene layers, that dip 32 to $35^{\circ}$ to the north northeast, provide a quantitative image of the geometry of faulting at this site (Figure $21 b$ ). The vertical offset of the terrace surface and of the unconformity by the thrust are the same, $4.01 \pm 0.3 \mathrm{~m}$. Slickensides on the thrust plane indicate almost pure dip-slip motion. Given the relatively shallow dip angle of the thrust $\left(32 \pm 2^{\circ} \mathrm{N}\right)$, the $4-\mathrm{m}$ offset implies $6.4 \pm 0.6 \mathrm{~m}$ of horizontal shortening, a rather large amount.

On the SPOT images and in the field, other south facing scarps with comparable strikes are visible west of the Anjihai river on remnant patches of the same $\mathrm{Q} 3$ terrace along the north limb of anticline A5, as well as across $\mathrm{f} 5$. Hence we infer the well-preserved, antithetic bedding-parallel thrust shown in Figure 21 to result from active flexural-slip folding within this limb. Such a process probably accommodates surface shortening here because a rather flat thrust remains blind under the anticline (Figure $3 b$ ). Additional offset measurements across these flexural-slip scarps and precise dating of the terrace Q3 would permit placing bounds on the rate of shortening across this anticline.

\section{Dushanzi Site (DSZ)}

Just east of Dushanzi, between anticlines A6 and A7 (Plate 2), two zones of left-stepping, en échelon scarps cut fan f6 (Figures 


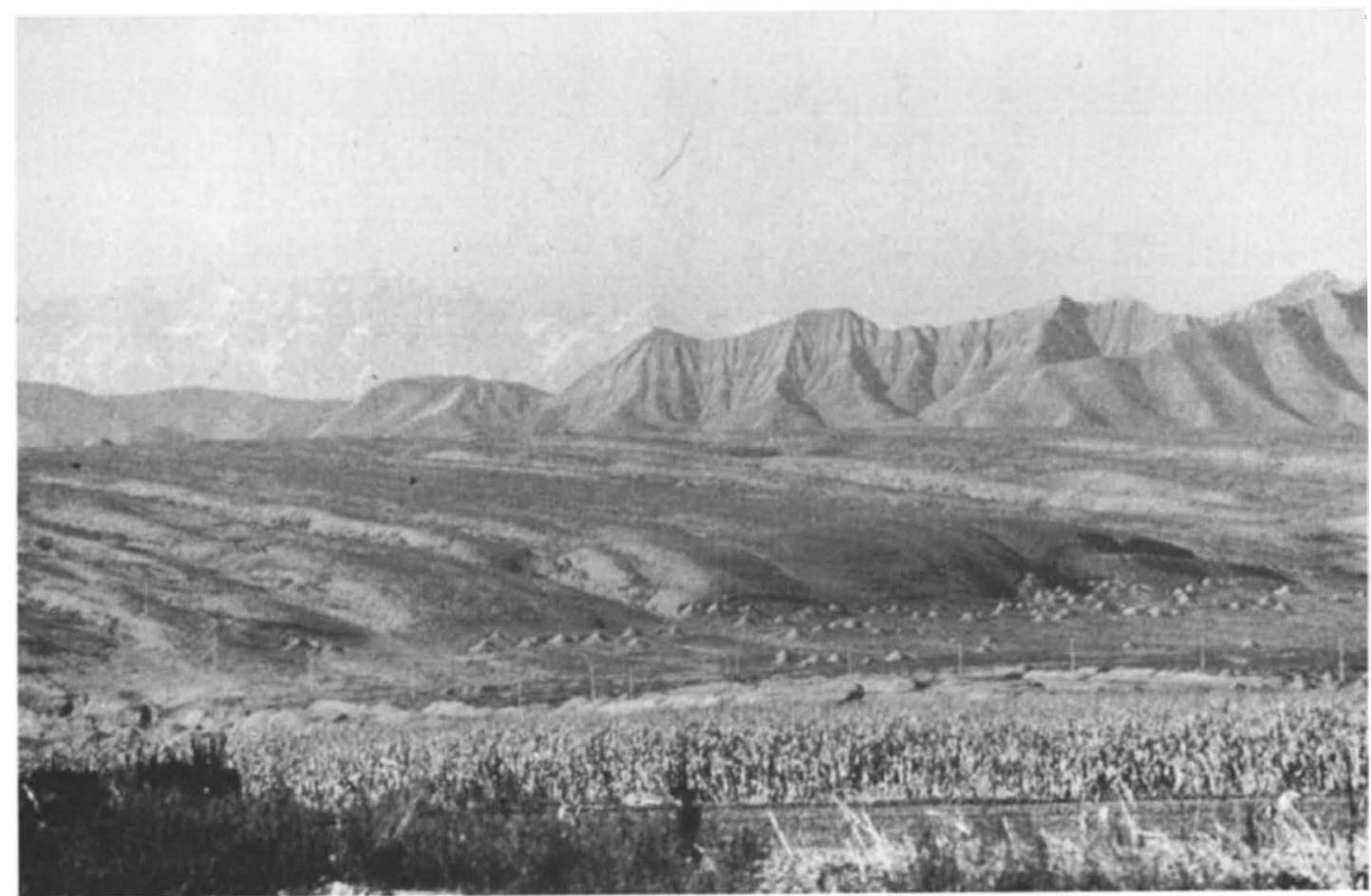

Fig. 13a. Southwest looking view of thrust scarp west of Linjia He (Plate 2 and Figure 11). Note south flank of anticline A3 in background center.

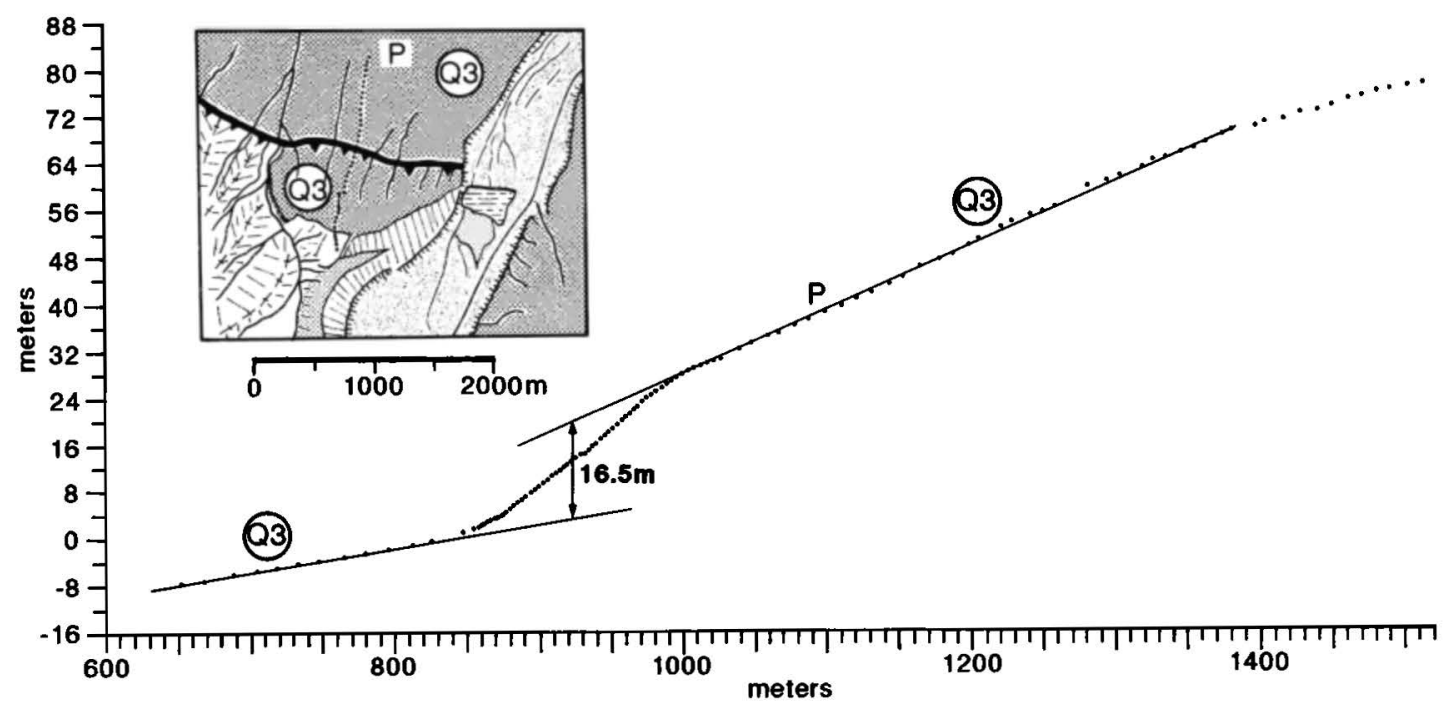

Fig. 13b. Topographic profile across Linjia He thrust scarp. Sketch map (insert) of box in Figure 12 shows location of profile.

22, 23, and 24, inset map). The northernmost zone strikes approximately east-west, parallel to, but more than $1 \mathrm{~km}$ south of, the northern edges of A6 and A7. It is associated with a flexure of the fan surface, down to the north, which is clearly visible on the SPOT images (Figure 22). In the field, the western segment of that flexure appears to be due to overlap of the en échelon, north facing thrust scarps, each of which is a few hundred meters long (Figures 23 and 24). Such a pattern of multiple faulting could result from splaying of the thrust into bedding planes within the overturned, northern limb of A6-A7 (see inset diagram in Figure 24).
Much of the second en echelon scarp zone strikes NW-SE, markedly oblique to A6-A7 (Figure 22). Towards the south, it veers to a $\mathrm{N} 150^{\circ} \mathrm{E}$ strike and acquires an extensional component, forming a small graben within the highest (Q3-4) part of the fan surface, where light-coloured silts are trapped (Figure 22). The more prominent, 6-8 $\mathrm{m}$ high, northeastern wall of the graben offsets right-laterally the linear, NE striking edge of that surface by $15-20 \mathrm{~m}$ (Figure 22). This offset, the extensional component of movement on the more southerly striking segment of this zone, and the left-stepping arrangement of the thrust scarps at its northwestern extremity are all 
N

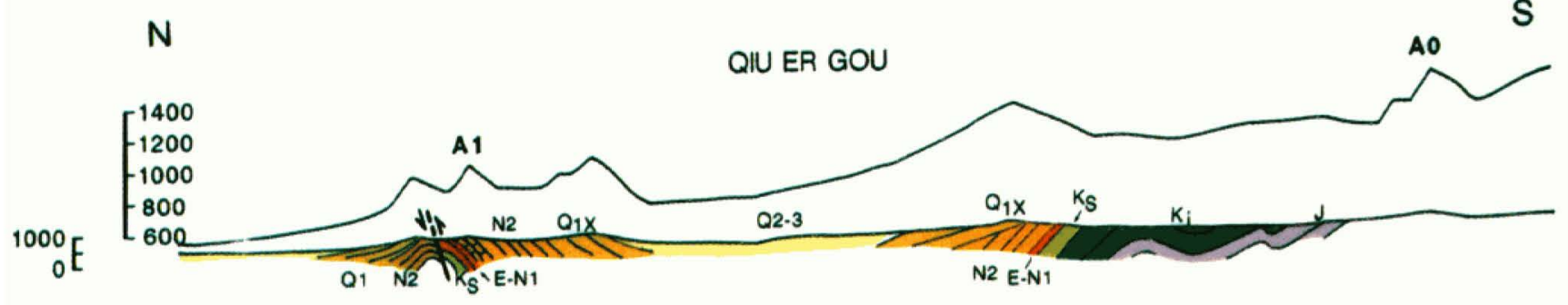

TASHI HE
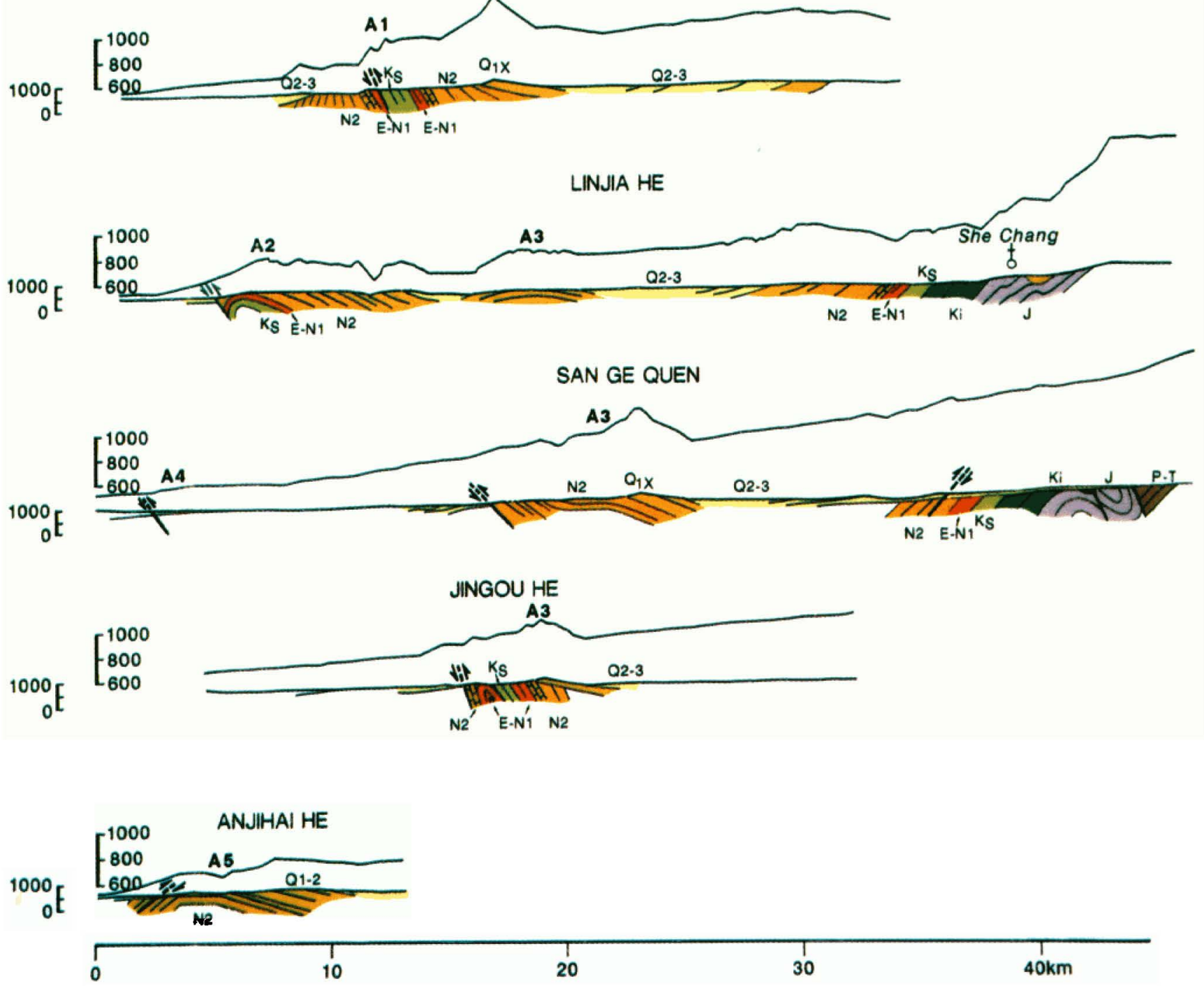

Plate 3. Geological sections (see location on Plate $2 b$ ). Relief (from 1/100 000 topographic maps of Xinjiang) is shown to scale on sections and with vertical exaggeration of 5 above. Bedding dip angles are from field measurements. Bold lines are thrust faults offsetting Holocene or Late Quaternary deposits.

compatible with a sizable component of right-lateral slip along this second fault zone, consistent with its orientation relative to the roughly $\mathrm{N}-\mathrm{S}$ direction of shortening. Along the flexure across the eastern part of $\mathrm{f6}$, north of the graben, multiple scarps (each at most $\approx 1 \mathrm{~m}$ high) face towards the south, consistent with flexural slip on north dipping beds, as observed towards the east along the north limb of A5-A6. The NW-SE striking fault across $\mathrm{f} 6$, which is probably the surface expression of a right-lateral ramp, thus appears to mark a transition zone between two different mechanisms of shortening within the A5A7 anticlinal row: flexural slip folding within a gentle flexure above a blind thrust to the east versus north-directed emergent thrusting of the recumbent limb of a more evolved fault propagation anticline to the west.

The scarps we measured in the westernmost part of 16 (Figure 24) are not much degraded, but we could not identify unambiguously the offset due to the last seismic event. By adding the multiple offsets derived from the combination of seven profiles levelled where the two scarp zones parallel each other and are closest (Figure 24), we obtain a total offset of $11.1 \pm 2.7 \mathrm{~m}$ of the surface of $\mathrm{f6}$ across the thrust along A7. Note that profile P4, which is $750 \mathrm{~m}$ long, shows little evidence of folding. The difference in slope between $P 2$ (about $3^{\circ} \mathrm{N}$ ) and P4 (about $1.5^{\circ} \mathrm{N}$ ) may be interpreted to result from folding. 


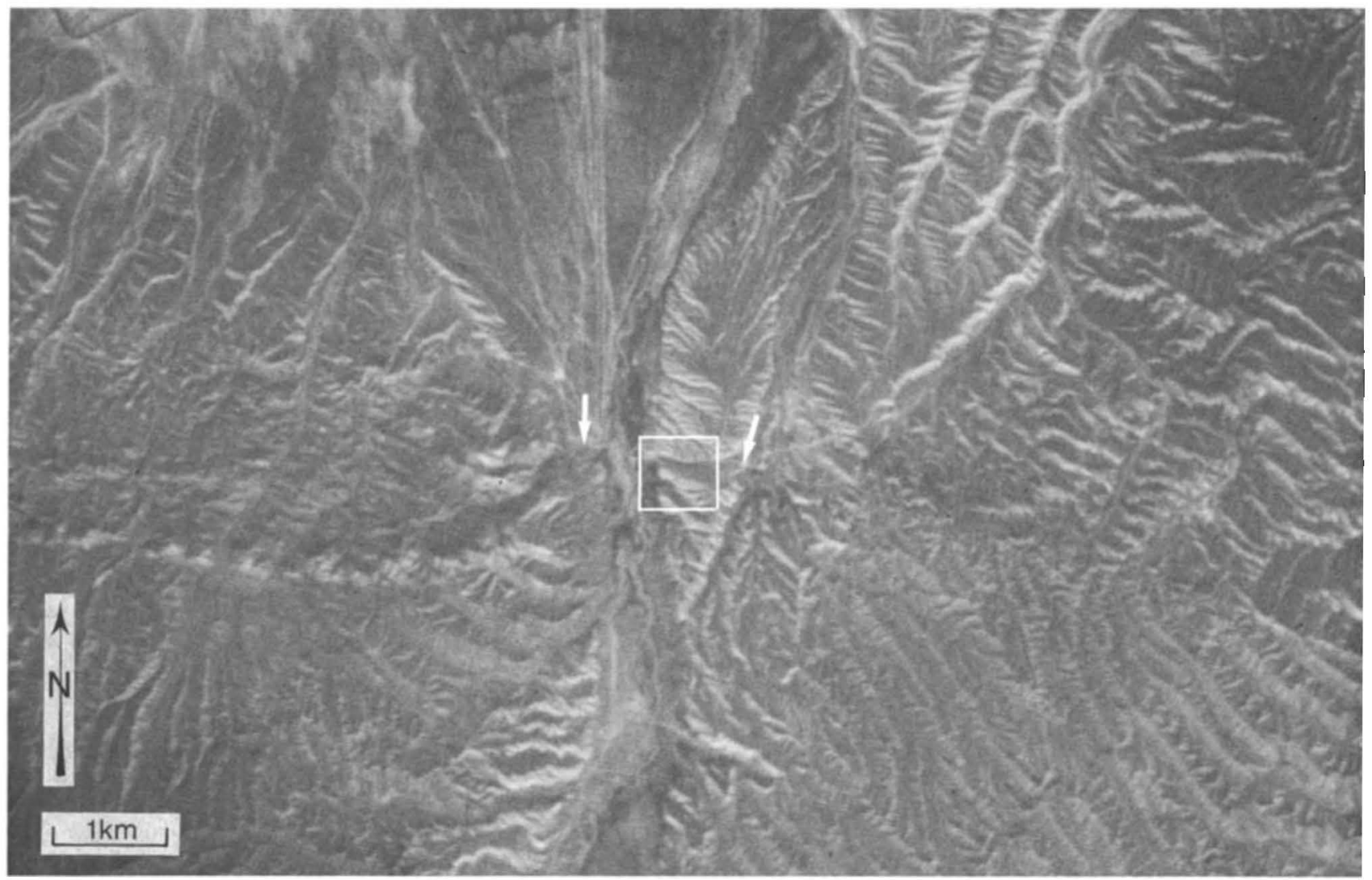

Fig. 14. SPOT view of thrust scarp across San Ge Quen narrows terraces (site SGQ, Plate $2 b$; scene KJ 214-261, july 7 1986). Arrows point to scarp. Box is area of field measurements.

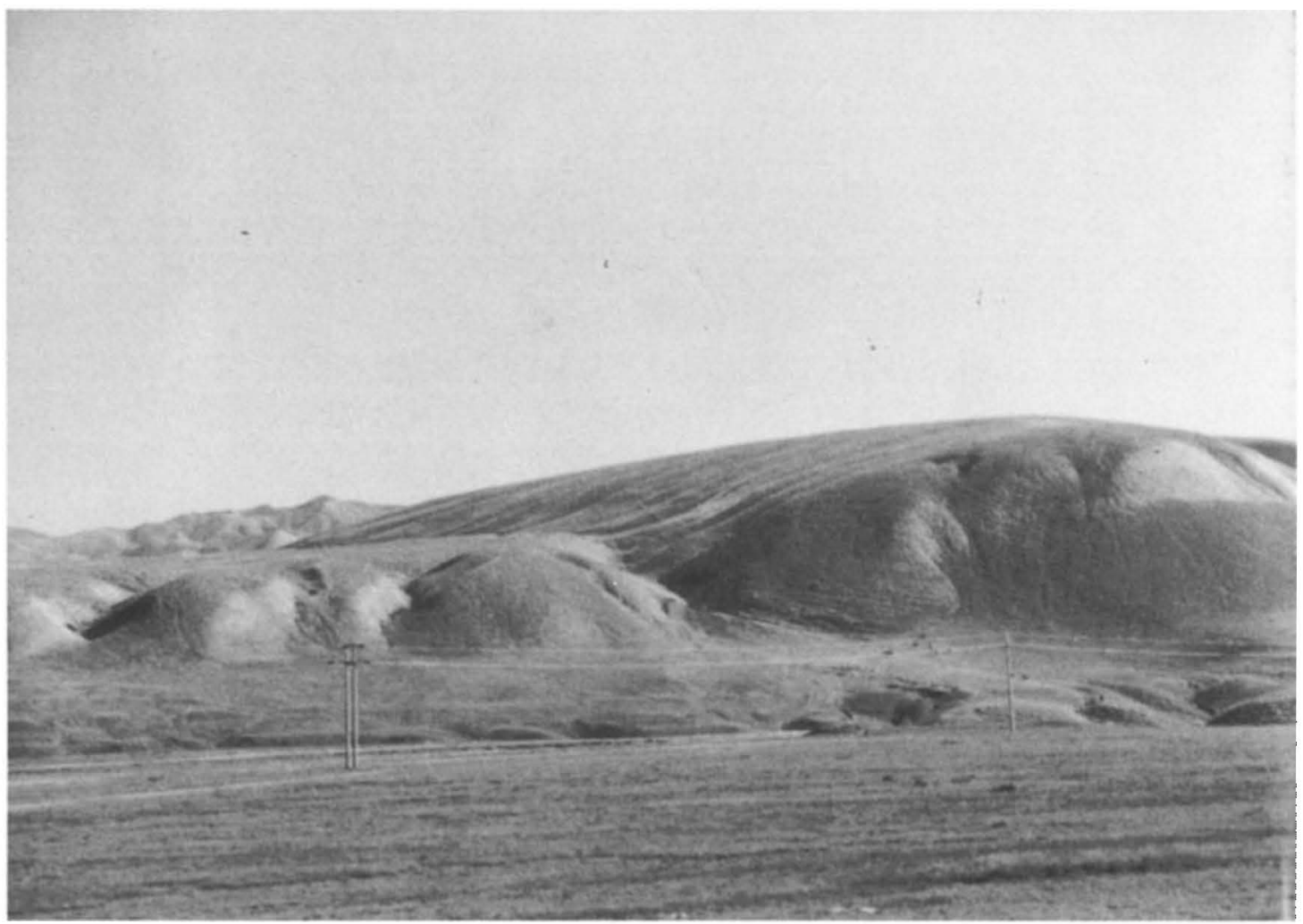

Fig. 15. East looking view of offset late Quaternary surface (Q3) at San Ge Quen. Note young scarp in foreground. 


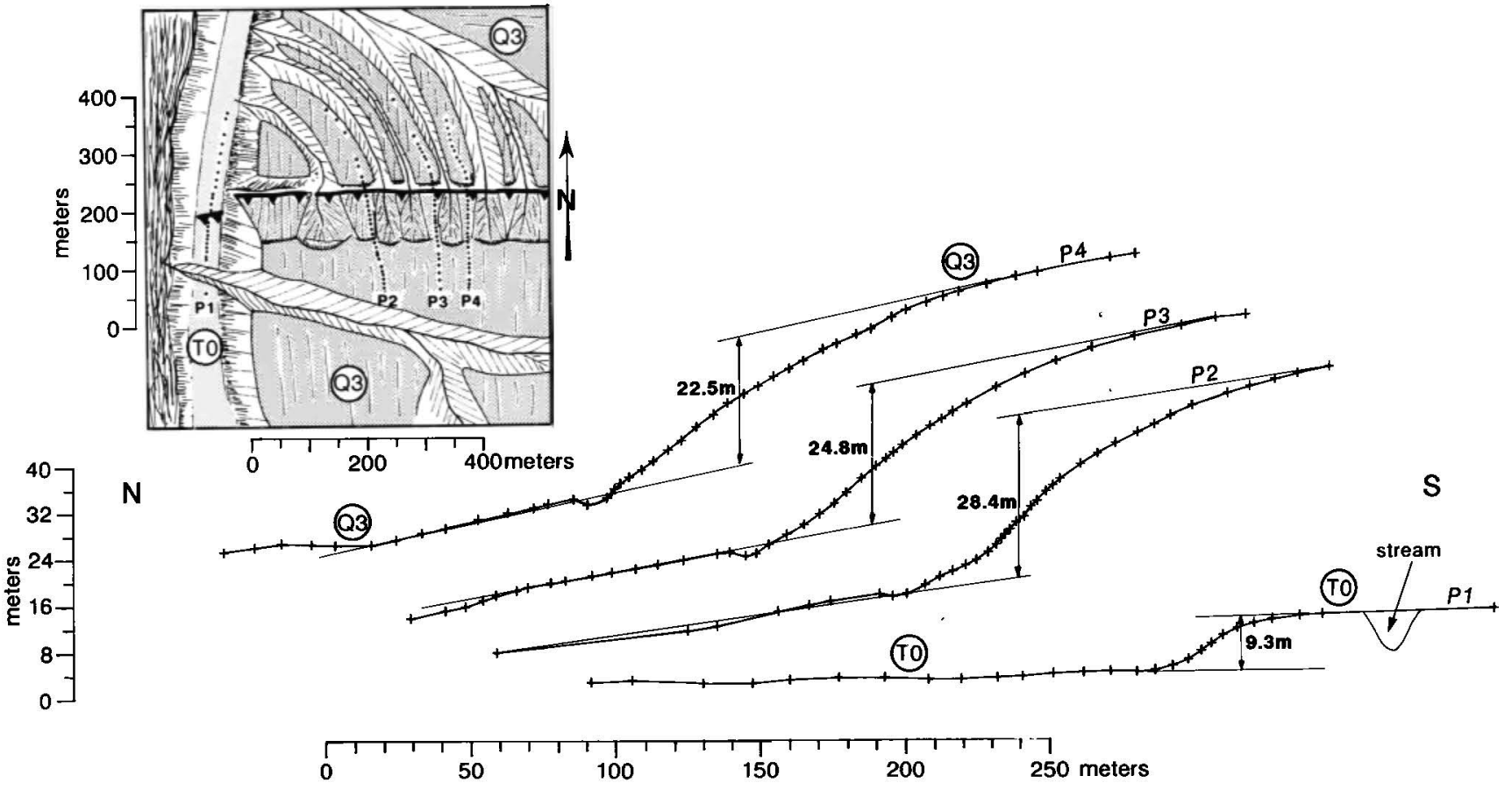

Fig. 16. Topographic profiles across fault scarp at site SGQ. P2 to P4 were run on remnant flats between gullies dissecting late Quaternary surface. Sketch map (insert) of box in Figure 14 shows location of profiles.

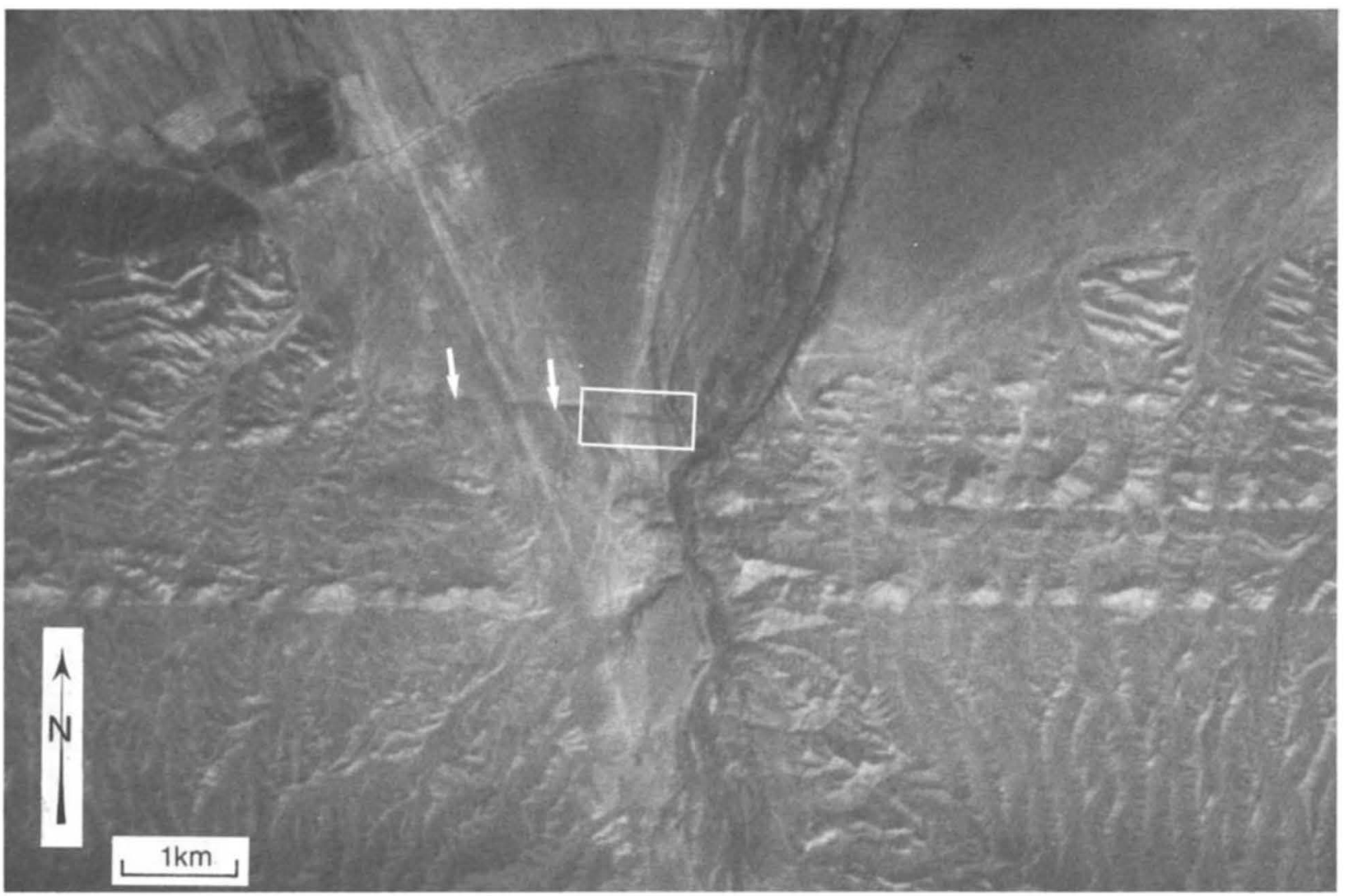

Fig. 17. SPOT view of thrust scarp across Jingou He narrows terraces (site JGH, Plate $2 b$; scene KJ 214-261, july 14, 1986). Arrows point to scarp. Box is area of field measurements. 


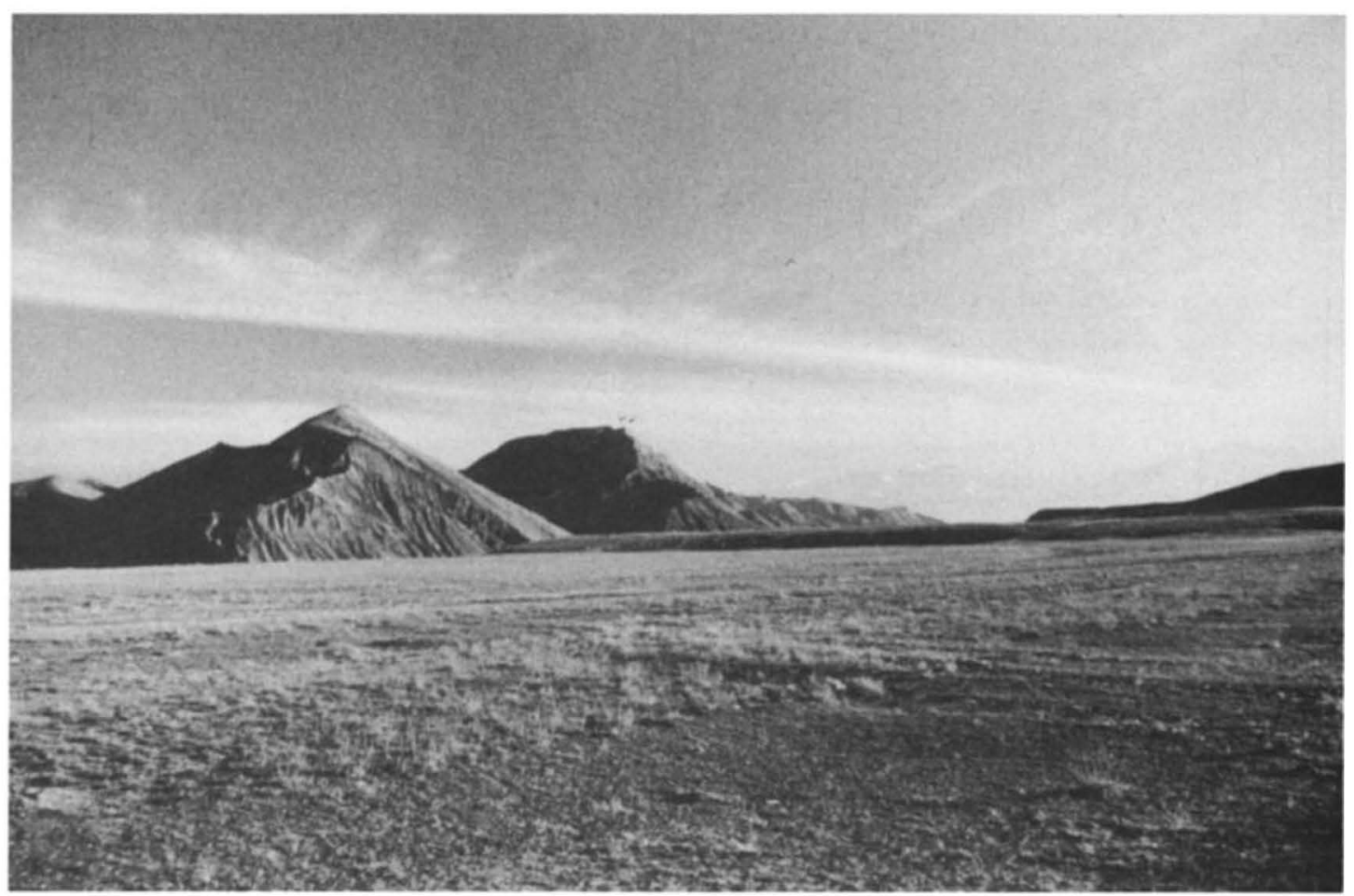

Fig. 18a. Southeast looking view of thrust scarp on upper terrace T0 at site JGH. Note prominent ramp placing greenish beds (Upper Cretaceous) on top of Tertiary red beds in background left. Note also perched Q2-3 conglomerates, unconformable on steep Neogene beds near top of middle hill.

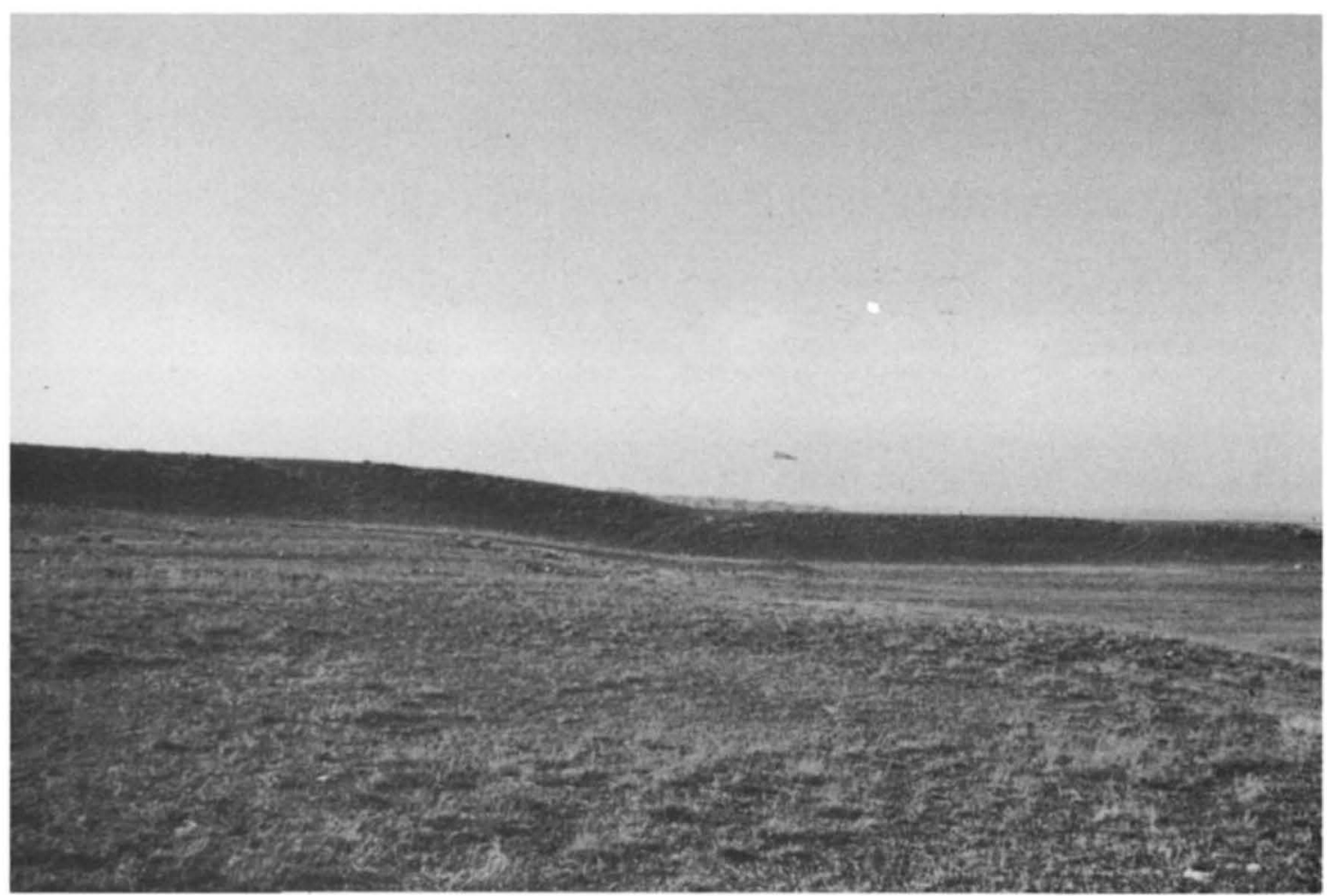

Fig. 18b. West looking view of offset T1-T2 terrace riser and of young seismic surface break in foreground. 


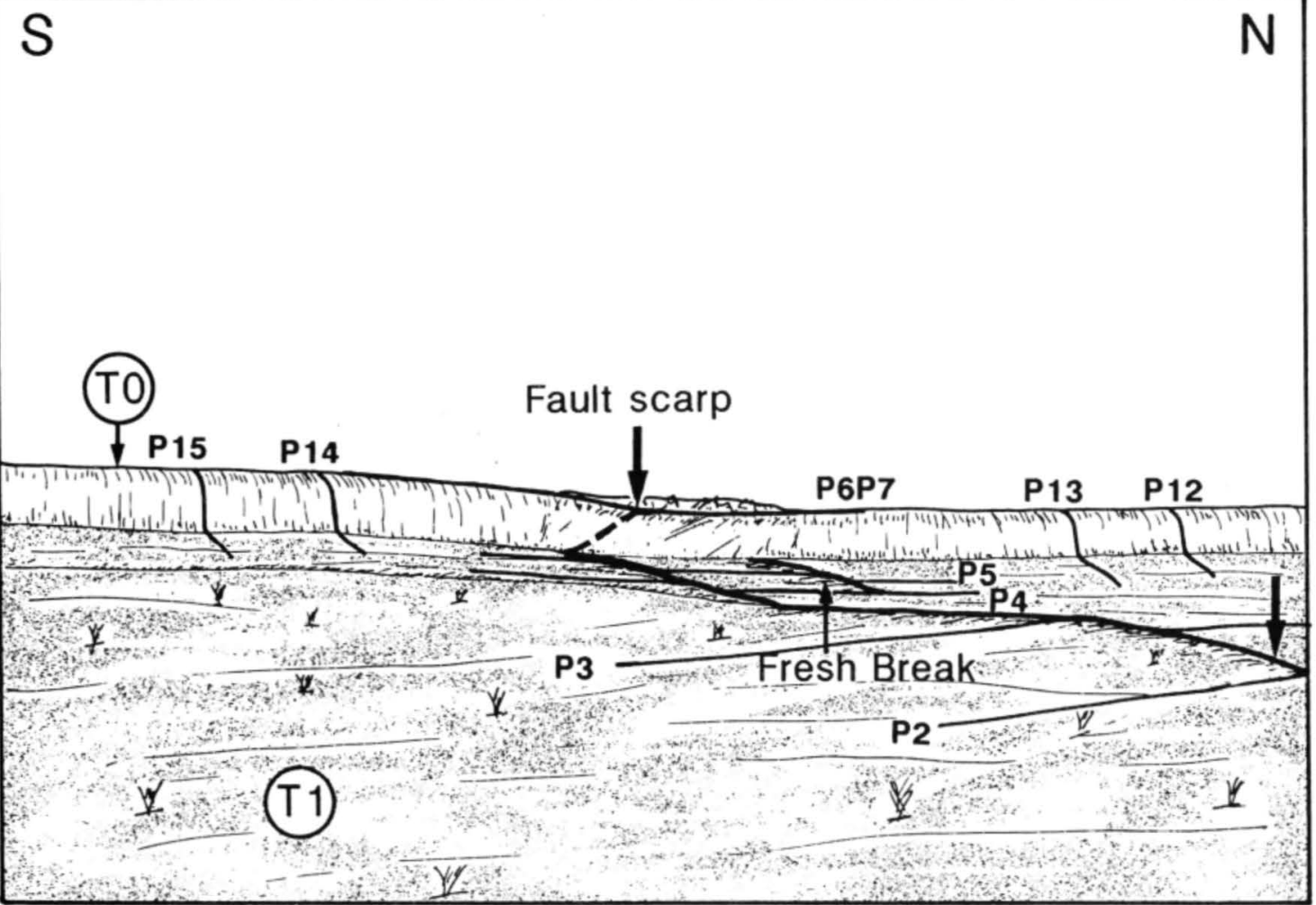

Fig. 18c. Sketch of Figure 18b. Position of profiles P2-P5 and P12-P15 is indicated.

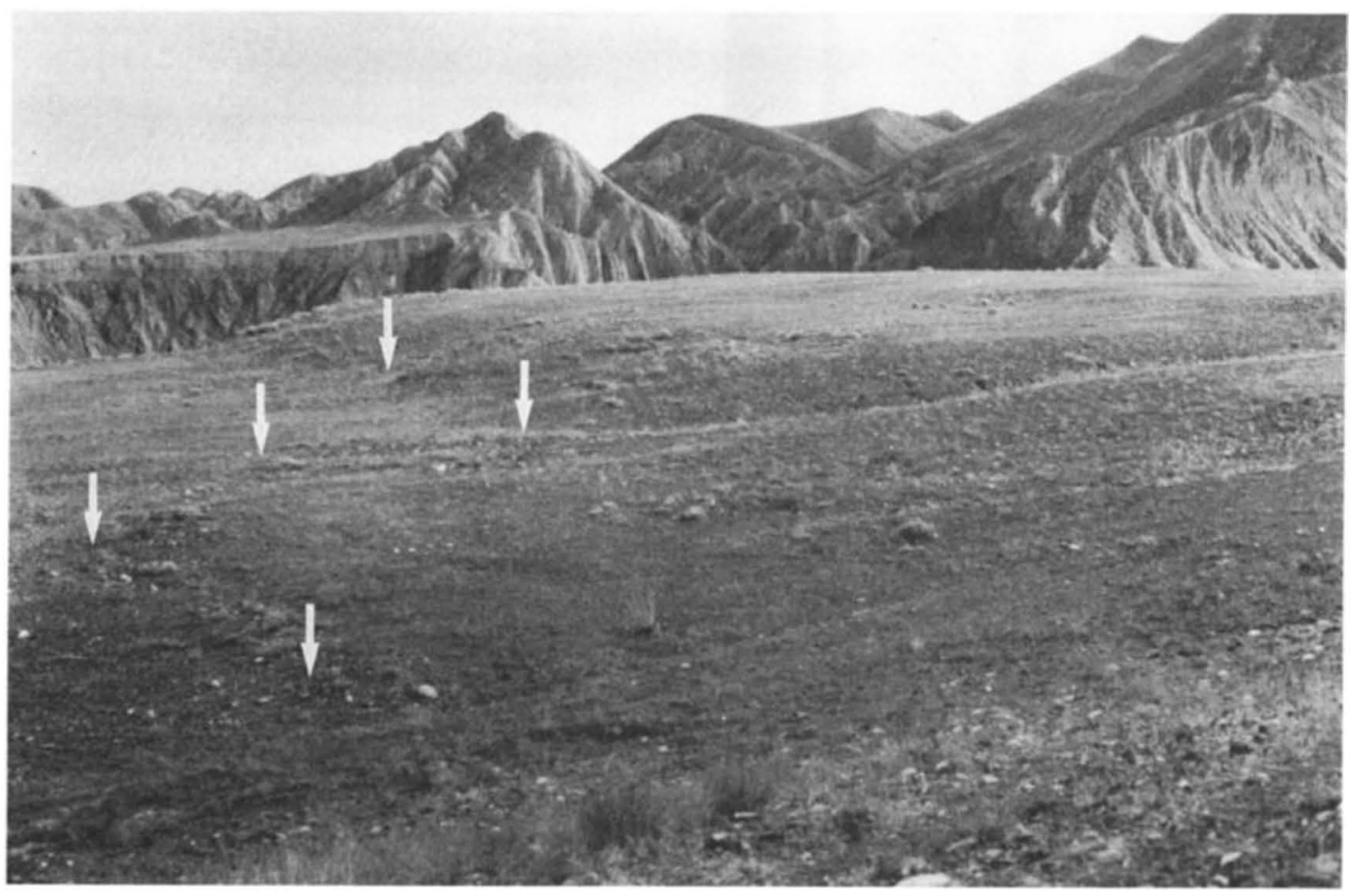

Fig. 18d. East looking view of tresh seismic scarplet (white arrows) in front of cumulative scarp on terrace T0 at site JGH. Note exhumed pebbles along zone of disrupted turf. 


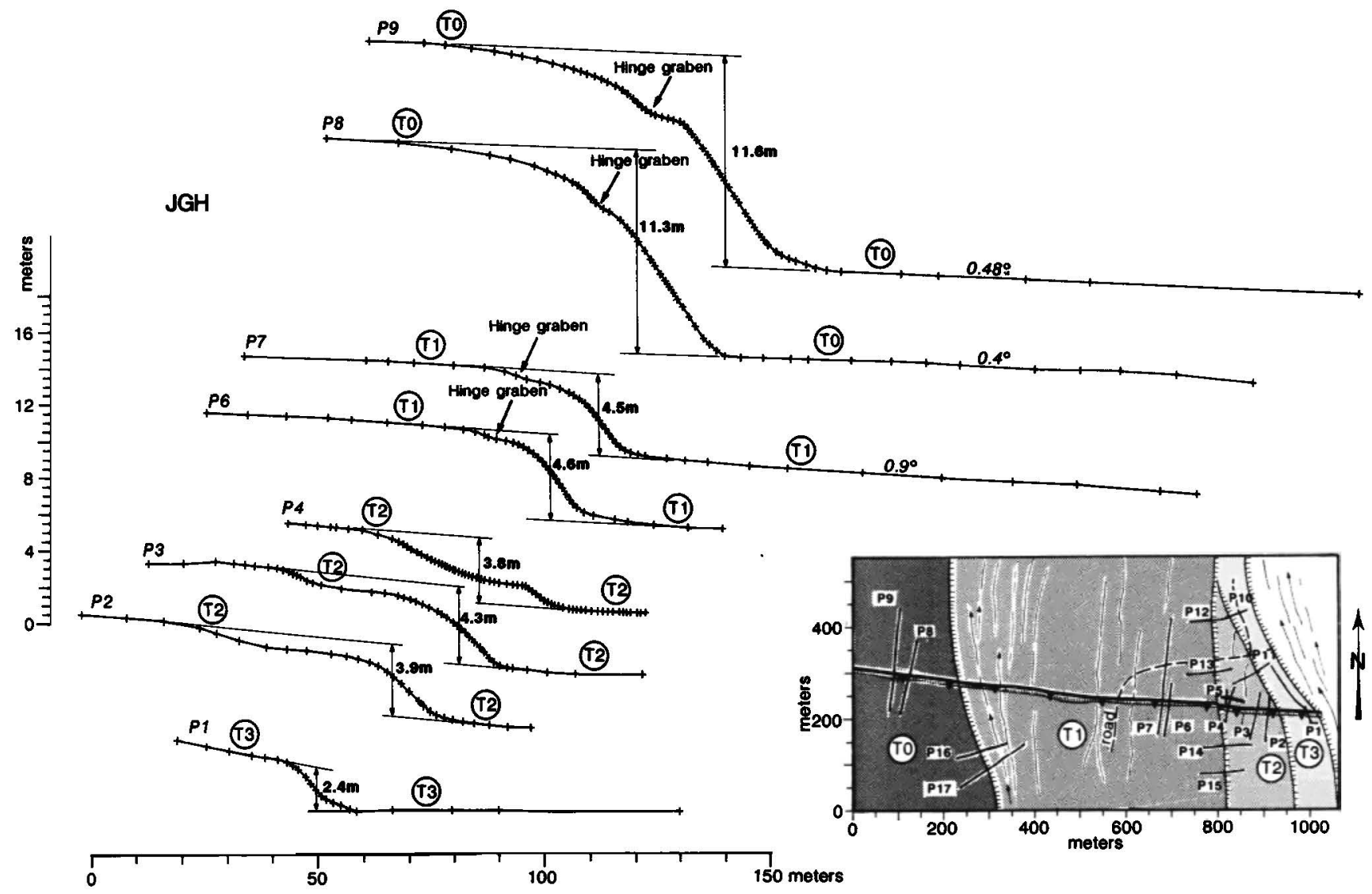

Fig. 19. Profiles transverse to thrust scarp at site JGH. Sketch map (insert) of box in Figure 17 shows position of scarp relative to terrace risers and location of profiles transverse to scarp and terrace risers (P1 to P17). T0 to T3 are terraces successively abandoned by Jingou He. Note small recent seismic offset $(\approx \mathrm{Im})$ near top of P3 and base of P4. Note also hinge graben at top of cumulative scarp on profiles P6-P9.

With the assumption that the surface of $\mathrm{f} 6$ is $10 \pm 2 \mathrm{ka}$ old, such a cumulative offset yields a vertical throw rate of $1.1 \pm 0.5 \mathrm{~mm} / \mathrm{yr}$, comparable to those inferred at sites along A1A3.

\section{HOLOCENE RATES OF DEGRADATION AND THROW}

The inference that the largest fans (f1-f6) are markers of the same morphogenetic episode and the assumption that this episode took place at $10 \pm 2 \mathrm{ka}$, near the onset of the Holocene period, are consistent with the offsets measured at six different sites. Cumulative offsets recorded by these early Holocene surfaces along the entire length of the active piedmont thrust are remarkably similar and cluster between 8.5 and $11.4 \mathrm{~m}$, with an average value of $10.2 \pm 0.7 \mathrm{~m}$ (Table 1 and Figure 25a). Such regularity is unexpected since the thrust is segmented and some of the offsets measured are across fans or terraces that are near the extremities of some of the thrust segments (Plate 2). It is probable that the similar offsets reflect the fact that the different thrusts ramp from a single flat at the base of the Cretaceous (Figure $3 a$ ). In any event, the average Holocene surface throw rate on the Tugulu-Dushanzi thrust appears to be uniform along strike, of the order of $1.0 \pm 0.3 \mathrm{~mm} / \mathrm{yr}$ (Table 4).

Older Quaternary surfaces (Q3) capping the folds on the sides of the river valleys have been offset by larger amounts (between 15.6 and $25 \mathrm{~m}$ ) and appear to have been warped $5-6^{\circ} \mathrm{N}$ by folding at sites LJH, SGQ, and AJH. Such surfaces are particularly well developed across the periclines of A1, A2, A3, and around AS. Folding of these surfaces probably occurs over the whole width $(10-15 \mathrm{~km})$ of the Tertiary anticlines (A1-A3), as shown in Figure $3 a$ and cannot be quantitatively assessed over the short length of our profiles. No clear trace of folding is visible on profiles measured on the early Holocene fans. The slope of these fans is, in general, small and comparable to the slope of the piedmont, but we cannot rule out that folding of the fans exists at a scale greater that the length of our profiles.

Episodes of river entrenchment and terrace deposition during the Holocene period have left lower inset terrace levels that are offset by lesser amounts. These terraces are more difficult to correlate from one valley to the next. Nevertheless, the morphological analysis of terrace risers at sites TSH and JGH indicates that terrace risers $(\mathrm{Ti}+1 / \mathrm{Ti}$ ) are all the more degraded since the terraces at their base (Ti) have been more offset by the thrust (Tables 1 and 3). Recall that the shape of a riser begins to degrade only after the terrace at its base has been abandoned by the river. Hence the degradation coefficient of a riser ( $\mathrm{Ti}+1 / \mathrm{Ti})$ relates to the terrace at its base (Ti) and is a crude measure of the age of abandonment of that terrace. On Figure $25 b$, we have thus plotted the degradation coefficients relative to those terraces as a function of their offset by the thrust. Also plotted as a function of their offsets are the degradation coefficients of the single seismic scarplets at site JGH. An important feature of this plot is that the degradation coefficients are roughly proportional to the vertical thrust offsets (Figure 25b). Since degradation and offset are unrelated functions of the climatic and tectonic 

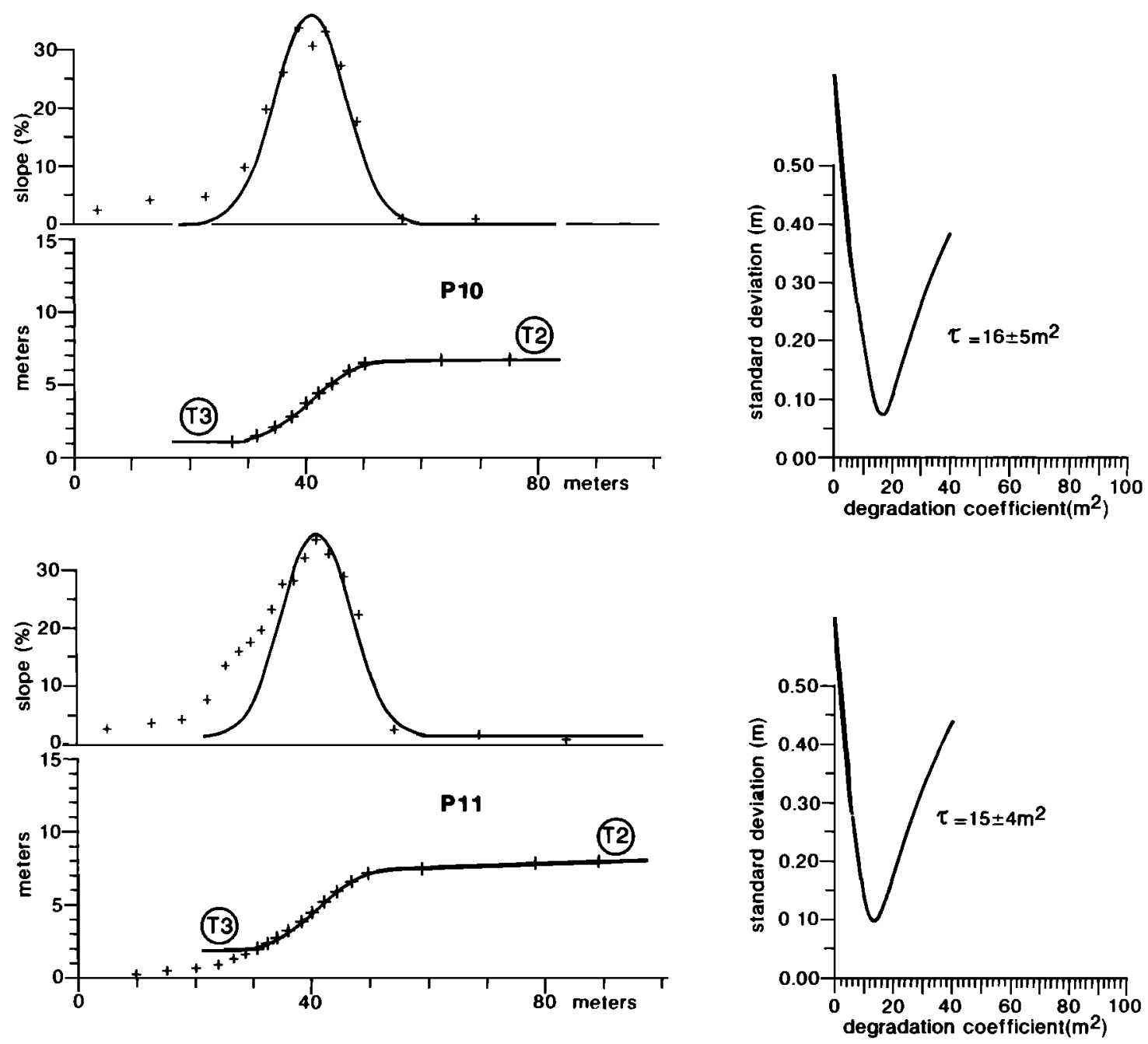

Fig. 20a. Morphological analysis of profiles at site JGH. P10 and P11, across T2-T3 terrace riser.

environments, respectively, the simplest way to account for such a linear dependence is to suppose that both the degradation and vertical throw rates have remained roughly constant since the abandonment of terrace T0, which we assume to have occurred near the onset of the Holocene $(10 \pm 2 \mathrm{ka})$.

Taking the throw rate estimated from the offset of TO at Jingou He to have been constant $(1.1 \pm 0.3 \mathrm{~mm} / \mathrm{yr})$ implies an age of $3.6 \pm 1.4 \mathrm{ka}$ for $\mathrm{T} 2$, which has been offset $4 \pm 0.4 \mathrm{~m}$. Since $\mathrm{T} 2$ is associated to a degradation coefficient of $19.5 \pm 3$ $\mathrm{m}^{2}$, this defines a uniform Holocene degradation rate $(\tau / \mathrm{t}$, equal to the mass diffusivity $k$ ) of $5.5 \pm 2.5 \mathrm{~m}^{2} / \mathrm{ka}$ (Figure $25 \mathrm{~b}$ ). Such a value is compatible with the semiarid climate of the area and is greater than that obtained in the more arid northern piedmont of the Qilian Shan in Gansu province $\left(3.3 \pm 1.7 \mathrm{~m}^{2} / \mathrm{ka}\right.$ [Tapponnier et al., 1990]). In addition, it brings all terrace offsets at sites JGH and TSH in rough agreement with a uniform Holocene throw rate of $1.0 \pm 0.3 \mathrm{~mm} / \mathrm{yr}$ (Figure $25 b$ ). Using this value, it is also possible to estimate the age of abandonment of $\mathrm{T} 3$ at site JGH $(2.76 \pm 1.3 \mathrm{ka})$ and of T1 at site TSH $(6.55 \pm 3.1 \mathrm{ka})$.

\section{SEISMIC BEHAVIOUR OF THE TUGULU-DUSHANZI THRUST}

At Hutubi and Jingou $\mathrm{He}$, we found rather fresh seismic breaks with similar vertical offsets, $0.85 \pm 0.15 \mathrm{~m}$ on average, along the 2-km-long cumulative scarps across fans $\mathrm{f} 1$ and $\mathrm{f} 6$ (Figures $6 d, 6 e, 7 a, 19 b, 19 c$, and 19d). Given the average
Holocene vertical throw rate of $1.0 \pm 0.3 \mathrm{~mm} /$ years derived above, the return period of events producing surface offsets of this size would be $850 \pm 380$ years. Evidence on the ground surface suggests that such breaks are only a few centuries old.

Thrust earthquakes with $M \leq 6.5$ rarely break the surface, particularly in China. Within $\approx 50 \mathrm{~km}$ of Manas, the only earthquakes with magnitudes large enough $(\approx 5.5)$ for fault plane solutions to be calculated since 1965 are the shocks of November 6, 1980, and March 3, 1983 [Ekström and England, 1989]. The former is located at a depth of $14 \mathrm{~km}$ under the edge of the Boro Horo Shan, about $50 \mathrm{~km}$ south of Manas. The latter is a rather deep event $(68 \mathrm{~km})$ located in the deeper crust or upper mantle $15-20 \mathrm{~km}$ south of site HTB. Given their modest sizes and deep hypocenters and the distance between their epicentral locations and the surface trace of the TuguluDushanzi thrust, it is doubtful that any of these events could have produced the recent seismic scarplets observed along this thrust. In the northern Tien Shan west of Urumqi, apart from the December $23,1906, M \approx 8.3$ Manas earthquake, the catalog of strong shocks of China [Institute of Geophysics, 1976] lists two earthquakes with $M \geq 7$ (March $10,1944, M \approx 7.2$, and March $8,1812,7<M<8$ ) and several shocks with $M \geq 6$, two of which significantly predate 1900 (June $18,1786, M \approx 6.5$, and February $9,1765, M \approx 6$ ) (Figure $2 a$ ). The epicenters of these shocks are all located at least $75 \mathrm{~km}$ west of Dushanzi, too far to 


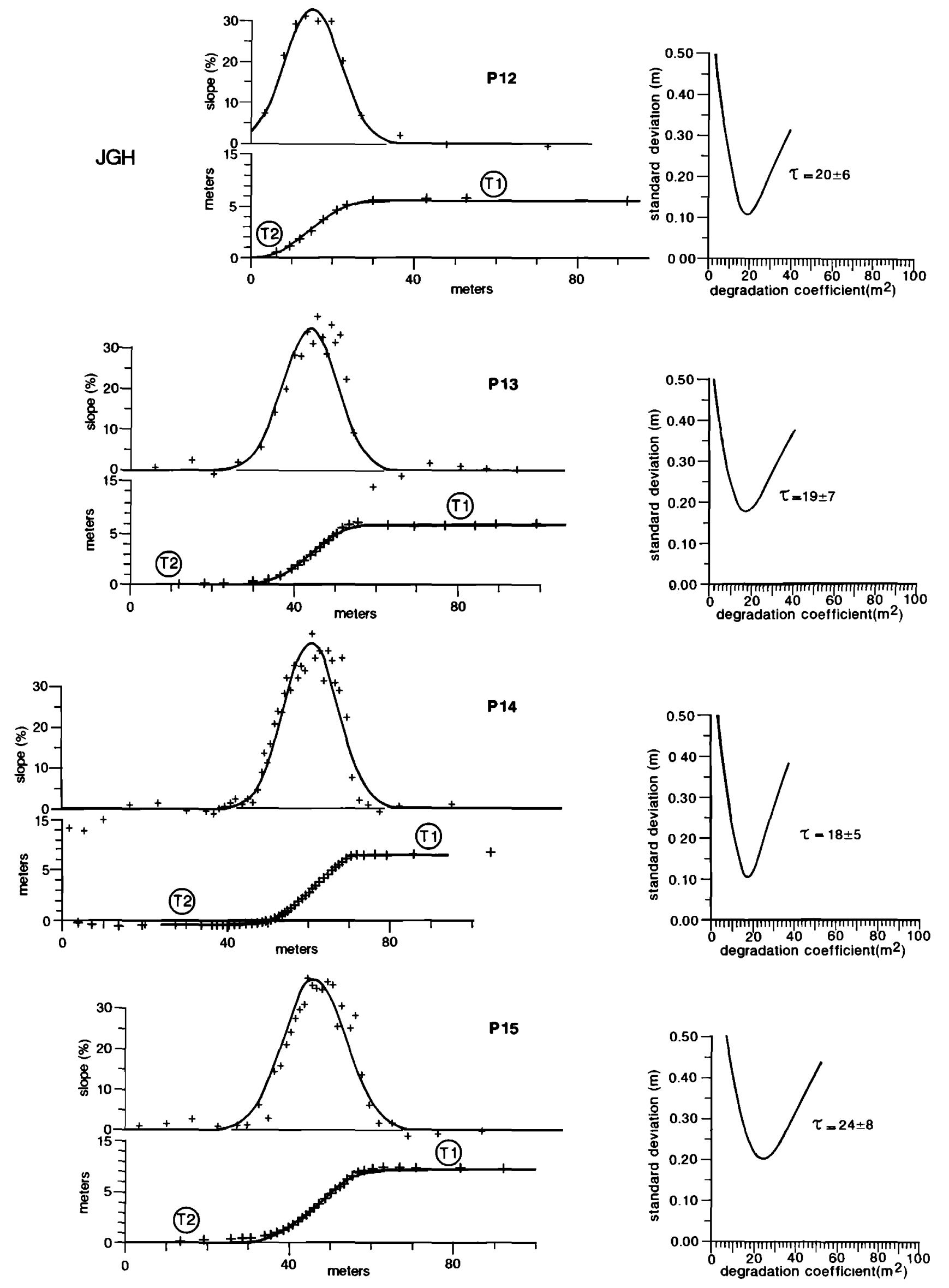

Fig. 20b. Morphological analysis of profiles at site JGH. P12 to P15, across T1-T2 terrace riser. 

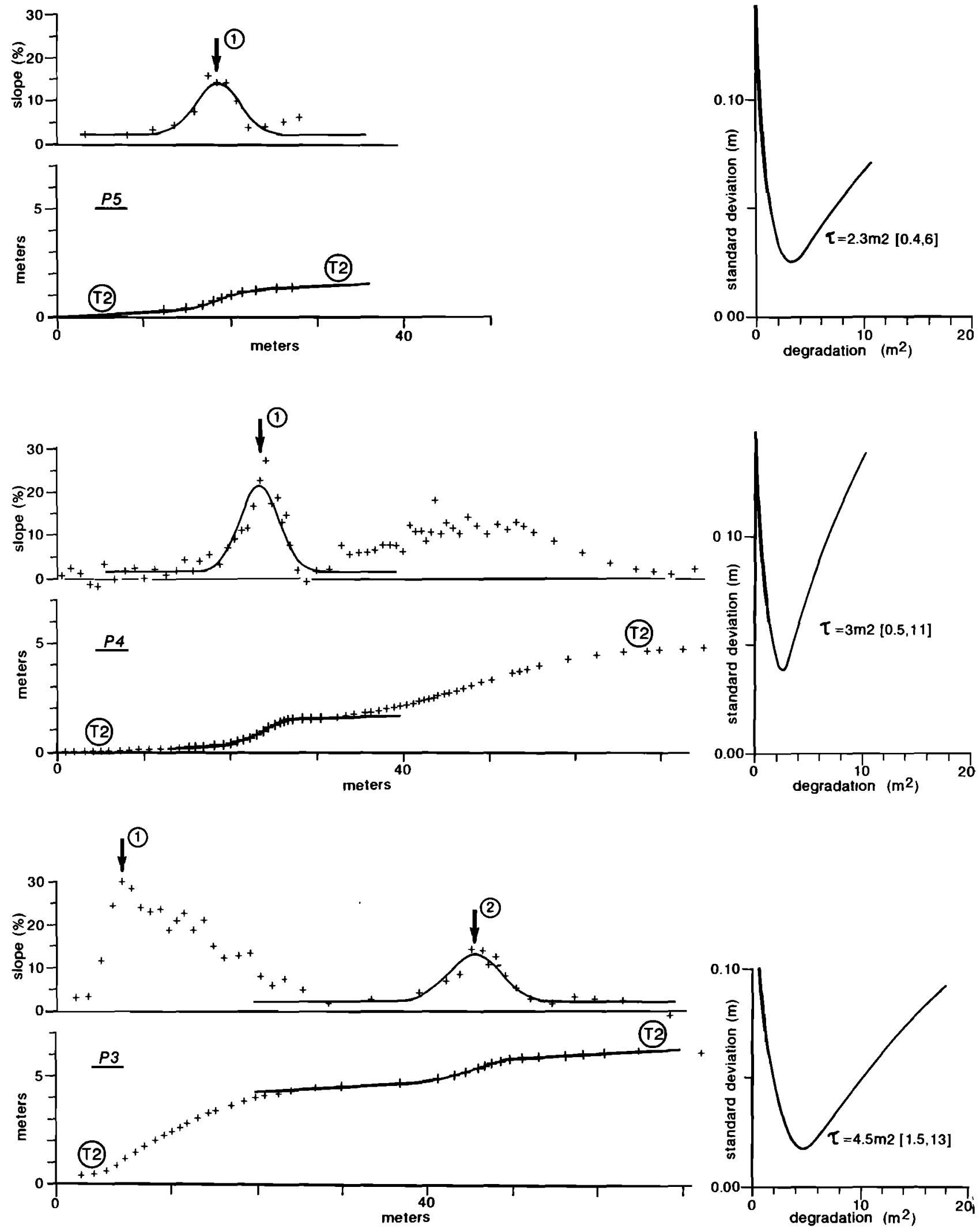

Fig. 20c. Morphological analysis of profiles at site JGH. P3 to P5, transverse to thrust scarp on terrace T2. See Figure 19 for location of profiles, and $10 \mathrm{c}$ for caption. Parameters and results are listed in Table 3.

have caused surface ruptures at JGH and HTB. The fact that the catalog lists earthquakes with magnitudes as small as 6 at least two centuries back implies that it is complete for shocks with $M>6.5$ during that period. Thus, unless the recent seismic scarplets at Hutubi and Jingou He are more than 225 years old, we find it plausible that they resulted from the 1906 Manas earthquake.

These two clear seismic scarplets are $110 \mathrm{~km}$ apart. With the exception of a metric, well-preserved crater at the base of the cumulative scarp on $\mathrm{T} 2$ in the Tashi He valley, apparently the 
TABLE 3. Morphological Analysis of Terrace Risers at Tashi He (TSH) and Jingou He (JGH) Sites, and of Surface Break of Recent Seismic Event at JGH

\begin{tabular}{ccccccc}
\hline $\begin{array}{c}\text { Site Terrace } \\
\text { level }\end{array}$ & Profile & $\begin{array}{c}\text { Offset, } \\
\mathrm{m}\end{array}$ & $\begin{array}{c}\text { Regional } \\
\text { Slope }\end{array}$ & $\begin{array}{c}\text { S. D., } \\
\mathrm{m}\end{array}$ & $\begin{array}{c}\text { Degradation } \\
\text { Coefficient, }\end{array}$ \\
\hline TSH & T1 & P7 & 11.8 & $0.6^{\circ}$ & 0.33 & $26<36<46$ \\
& & & & & & \\
JGH & T3 & P10 & 5.6 & $0^{\circ}$ & 0.07 & $13<15.8<21$ \\
& P11 & 5.6 & $0.8^{\circ}$ & 0.10 & $10<14.8<18.5$ \\
& & & & & $15.2 \pm 3$ \\
& & & & & \\
& T2 & P12 & 5.5 & $0^{\circ}$ & 0.11 & $14<20.0<26$ \\
& P13 & 5.9 & $0^{\circ}$ & 0.18 & $11<18.8<25$ \\
& P14 & 6.8 & $0^{\circ}$ & 0.11 & $14<17.8<23$ \\
& P15 & 7.1 & $0^{\circ}$ & 0.20 & $16<24.0<33$ \\
& & & & & $19.5 \pm 3$ \\
& & & & & \\
& & & & \\
r.s.e. & P3 & .82 & $1.4^{\circ}$ & 0.017 & $3<4.5<13$ \\
& P4 & .74 & $1.4^{\circ}$ & 0.025 & $.5<3.0<11$ \\
& P5 & 1.07 & $1.0^{\circ}$ & 0.039 & $.4<2.3<6$ \\
& & & & & \\
\hline
\end{tabular}

Initial scarp slope is assumed to be angle of repose $\left(35^{\circ}\right)$. Values of minimum standard deviation between measured and computed profiles are shown in column 6 .

result of a seismic sand blow, we saw no unmistakable evidence of recent seismic surface dislocation or related phenomena between Hutubi and Jingou He. We believe this to be due to the greater "anthropisation" (man-made degradation) and smaller widths of the youngest terraces at those sites. Note that even at the two sites where clear seismic dislocations were observed, and despite the length of the cumulative scarps there, such dislocations were not distinct everywhere, being sometimes "hidden" within the steep slope of these scarps (e.g., Figure 20c).

In keeping with the hypothesis that the four ramps along $A 1$, $A 2, A 3$, and $A 7$ root at a depth of $6-7 \mathrm{~km}$ into a unique decollement (Figure $3 a$ ) and with the observation that a crustal thrust ramp under the rising Boro Horo range does not surface at the range front in the mesoseismal region of the great 1906 earthquake, it is worth examining how a structure comprising a deep basement ramp under the range, a gently dipping flat in the foreland and shallow ramps under the piedmont anticlines could have generated a moment compatible with the magnitude of this earthquake.

The seismic moment of an earthquake is

$$
M_{0}=\mu L W u,
$$

where $\mu$ is the shear modulus, $L$ is the fault length, $W$ is the fault width, and $u$ is the mean slip during the earthquake [e.g., Aki, 1966]. The length of the thrust activated in 1906 is at least 110 $\mathrm{km}$. If the 1906 break reached fan f6 near Dushanzi, the maximum length of that thrust could have been nearly $200 \mathrm{~km}$. In order to estimate the width of the thrust, we assume a geometry similar to that represented in Figure 26. Centroid depths of earthquakes along the northern Tien Shan indicate that the crust is seismogenic to depths of at least $40 \mathrm{~km}$ (Figure 2 and Plate 1 Nelson et al., [1987]). Thus we take the thrust to be composed of a steep crustal ramp dipping $45^{\circ} \mathrm{S}$ under the Boro Horo range from $40-50$ to $15 \mathrm{~km}$ and of a flatter plane approximating the succession of flats and ramps between the range front and the surface trace, over a distance of about $30 \mathrm{~km}$ under the piedmont. This yields a fault width of $65-85 \mathrm{~km}$. The surface throw of $0.85 \pm 0.15 \mathrm{~m}$ observed at sites HTB and JGH is compatible with $1 \pm 0.3 \mathrm{~m}$ of pure dip slip on a thrust dipping $50^{\circ}-60^{\circ} \mathrm{S}$ at the surface. Taking $\mu=3.3 \times 10^{10} \mathrm{~N} / \mathrm{m}^{2}$,
$L=150 \pm 50 \mathrm{~km}, W=75 \pm 10 \mathrm{~km}$, and $u=1 \pm 0.3 \mathrm{~m}$, the seismic moment $M_{0}$ obtained from (1) is between 1.5 and $7.3 \times 10^{20} \mathrm{~N} \mathrm{~m}$ (Table 5).

Despite systematic bias depending on the region and magnitude, seismic moments and Ms magnitudes generally correlate [e.g., Ekström and Dziewonski, 1988]. The moment magnitude introduced by Kanamori [1977],

$$
M_{\mathrm{w}}=2 / 3 \log M_{0}-6.01
$$

agrees well with $M_{\mathrm{s}}$ for events with $M_{\mathrm{s}} \geq 6.5$ [Ekström and Dziewonski, 1988]. Here (4) yields $M_{\mathrm{w}}$ between 7.4 and 7.9 for $M_{0}$ between 1.5 and $7.3 \times 10^{20} \mathrm{~N} \mathrm{~m}$ (Table 5). The estimated rupture parameters thus appear to be too small to account for the reported magnitude $M_{\mathrm{s}} \approx 8.3$ [Molnar and Deng, 1984] of the 1906 Manas earthquake.

It is possible that this magnitude has been overstimated. In fact from calibration of the effective gain of the seismographs used during the period from 1897 to 1912, Abe and Noguchi [1983] infer that the surface wave magnitudes of the large shallow earthquakes between 1904 and 1909 have been systematically overestimated, by 0.3 to 0.5 units on average. For the 1906 Manas earthquake, they propose a reevaluated magnitude of $M_{\mathrm{s}} \approx 7.3$. We doubt that the magnitude of the Manas earthquake is that low, however, for the following reasons. First, the mesoseismal area deduced from the intensity distribution of that earthquake is comparable to that of the September 18, 1951, $M_{\mathrm{s}} \approx 8$, Damxung earthquake [Ding Guoyu, 1985], which ruptured a 90-km-long fault with an average horizontal slip of $8 \pm 2 \mathrm{~m}$ [Armijo et al., 1989]. Second, Abe and Noguchi's [1983] revised magnitude for the great Tannu-Ola earthquake of July 23, 1905, in Mongolia is only 7.7 , while the break it generated was $370 \mathrm{~km}$ long with amounts of slip in excess of $12 \mathrm{~m}$ [Florensov and Solonenko, 1965; Baljinnyam et al., Ruptures of major earthquakes and active deformation in Mongolia and its surroundings, submitted to Journal of Geophysical Research, 1992], rupture parameters that are inconsistent with a magnitude of less than $M_{s} \approx 8$. These two examples for which fieldwork constrains the seismic parameters imply that Abe and Noguchi's [1983] revised magnitude of 7.2 for the 1906 Manas earthquake is a gross underestimate. From the intensity distribution of that earthquake and by comparison with other large shocks in Asia, a value of $M_{\mathrm{S}} \approx 8 \pm 0.2$ appears to us to be the most plausible.

In fact, scaling laws suggest that even our estimate of the 1906 Manas earthquake's moment is an underestimate. For earthquakes of large magnitude the mean slip $u$ is generally proportional to the rupture length $L$ [e.g., Scholz, 1982; Scholz et al., 1986]. For intraplate thrust events, Scholz et al. [1986] find a proportionality constant of roughly $6 \times 10^{-5}$,

$$
u=6 \times 10^{-5} L
$$

Although significant departures from the average scaling law are frequent, a minimum rupture length of $100 \mathrm{~km}$ would be most consistent with a mean slip of about $6 \mathrm{~m}$, much larger than the surface slip value of $1 \pm 0.3 \mathrm{~m}$ measured at sites HTB and JGH. That shallow thrusting in the piedmont north of the range is coupled with fault propagation folding (A1, A2, A3, and A7, Plate 2) supports the inference that fault slip at the surface is only a fraction of that at depth. Slip on blind thrusts under folds A5 and A6 (Figure $3 b$ ) probably absorbs additional strain. We conclude that a mean slip of $3.5 \pm 2 \mathrm{~m}$ at depth on a fault plane $150 \times 75 \mathrm{~km}^{2}$ corresponding to magnitudes $M_{\mathrm{w}}$ between 7.8 and 8.2 (Table 5) accounts best for the most plausible magnitude 


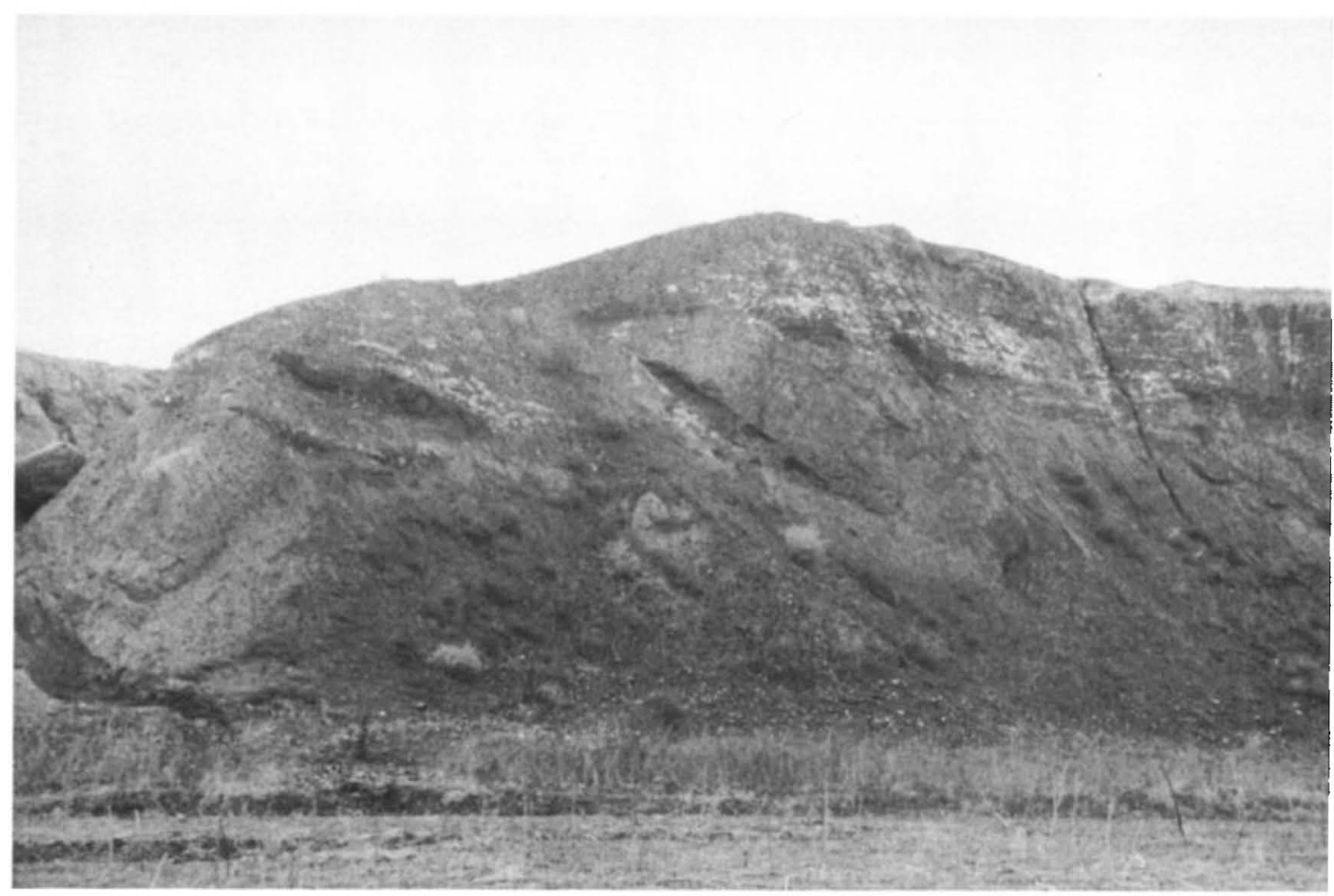

Fig. 21a. East looking view of north-dipping, bedding-parallel thrust fault in Pliocene of west bank of Anjihai He (site AJH, Plate $2 b$ ), offsetting unconformable late Quaternary conglomeratic layer.
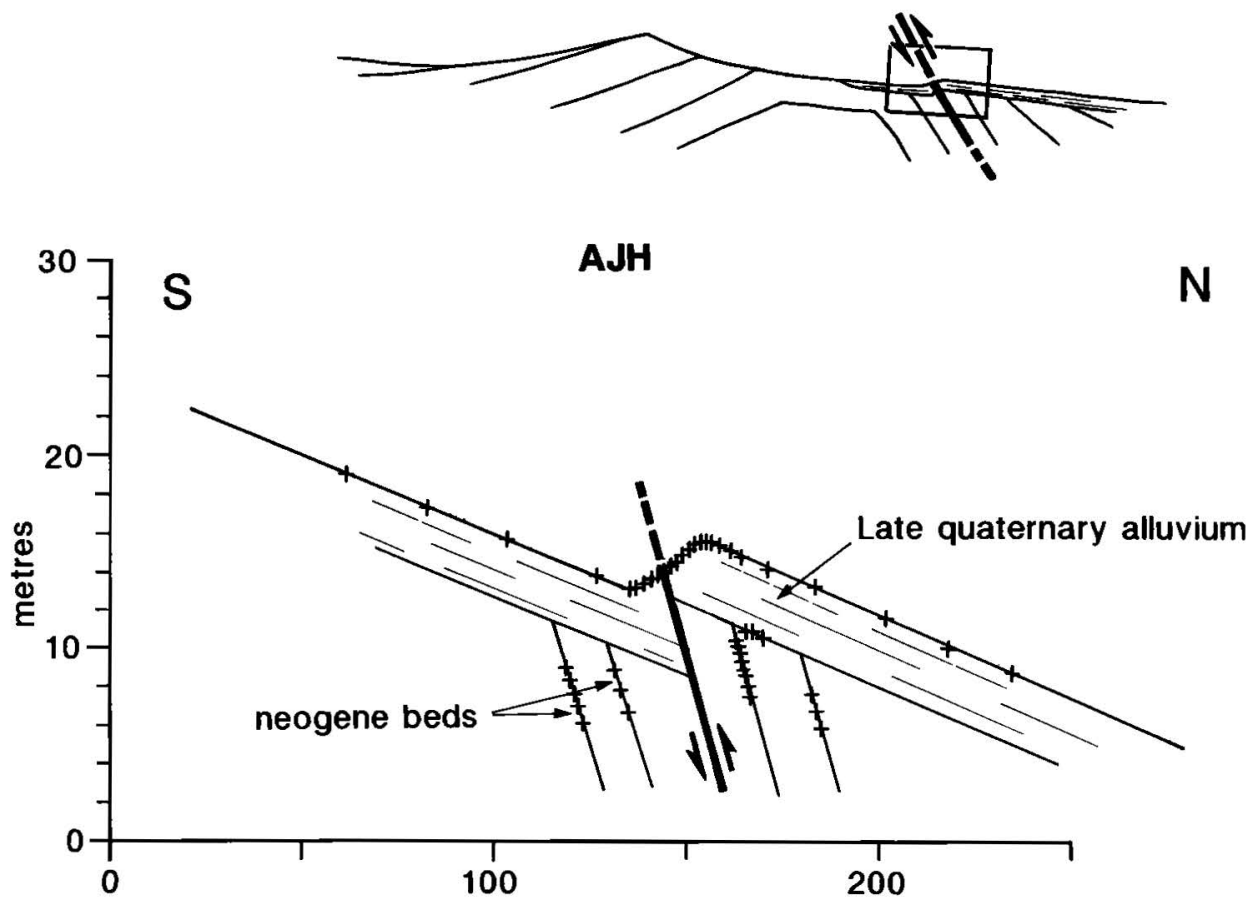

Fig. 21b. Profile transverse to thrust scarp at site AJH. Projection corresponds approximately to photograph in Figure $21 a$. Points were also levelled along unconformity and top edges of underlying beds. Inset sketch (top) shows position of beddingslip thrust within anticline A5.

$\left(M_{\mathrm{s}}=8 \pm 0.2\right)$ of the 1906 Manas earthquake, within the limits set by field evidence and scaling laws.

In summary, when brought together, the inferences derived from surface faulting, Quaternary geology, deep structure, seimicity, and measurements of the Holocene morphology suggest that the active thrust that surfaces along the TuguluDushanzi fold zone ramps down into the crust under the Boro Horo range, $30 \mathrm{~km}$ south of the folds. This thrust is the main seismogenic fault of the Dzungarian Tien Shan between $85^{\circ} \mathrm{E}$ and $87^{\circ} \mathrm{E}$. It was probably activated by the $M_{\mathrm{s}}=8 \pm 0.2$, 


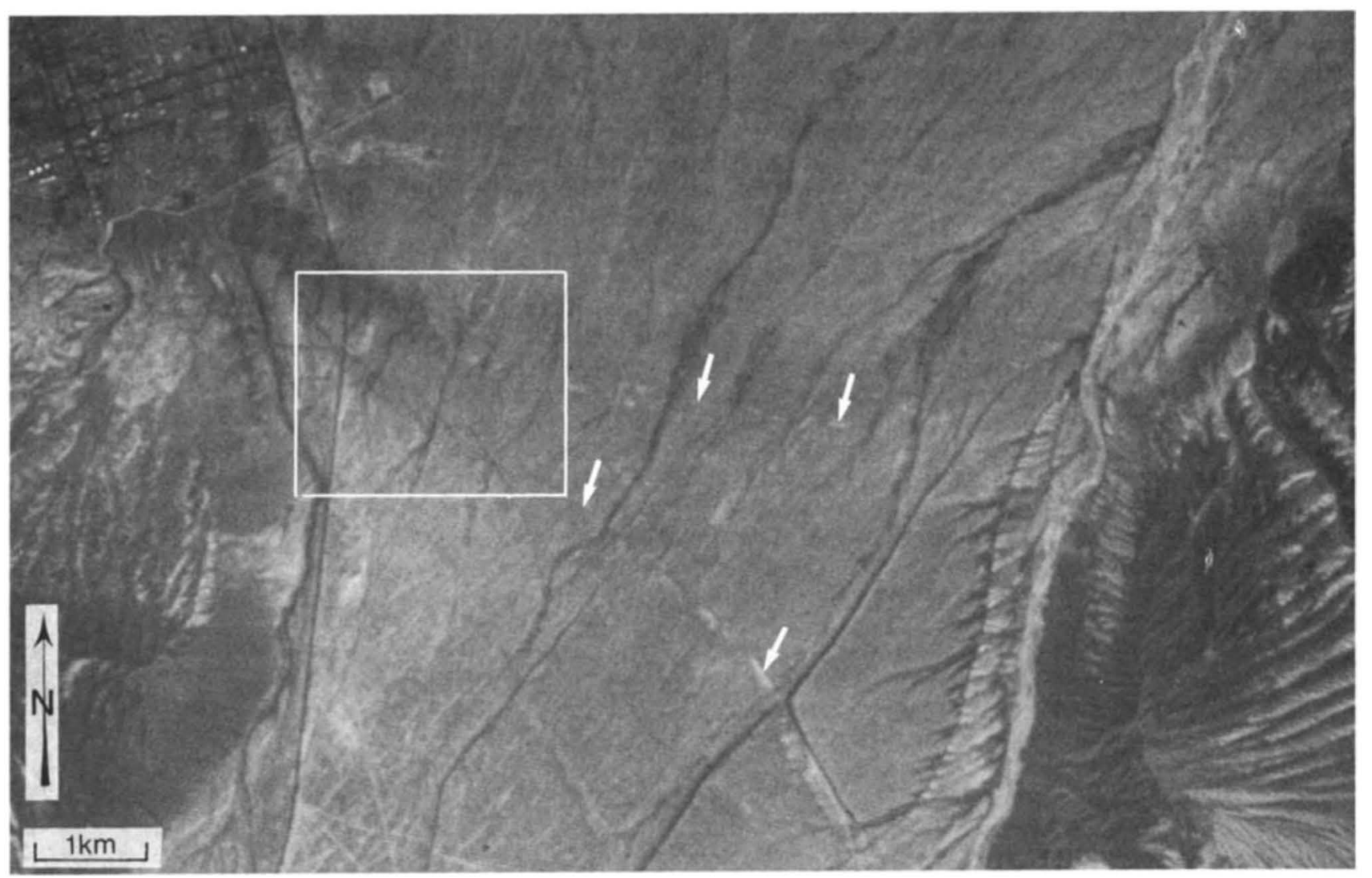

Fig. 22. SPOT view of scarps across fan in narrows east of Dushanzi (site DSZ, Plate $2 b$; scene KJ 213-261, july 14, 1986). Arrows point to scarps. Box is area of field measurements.

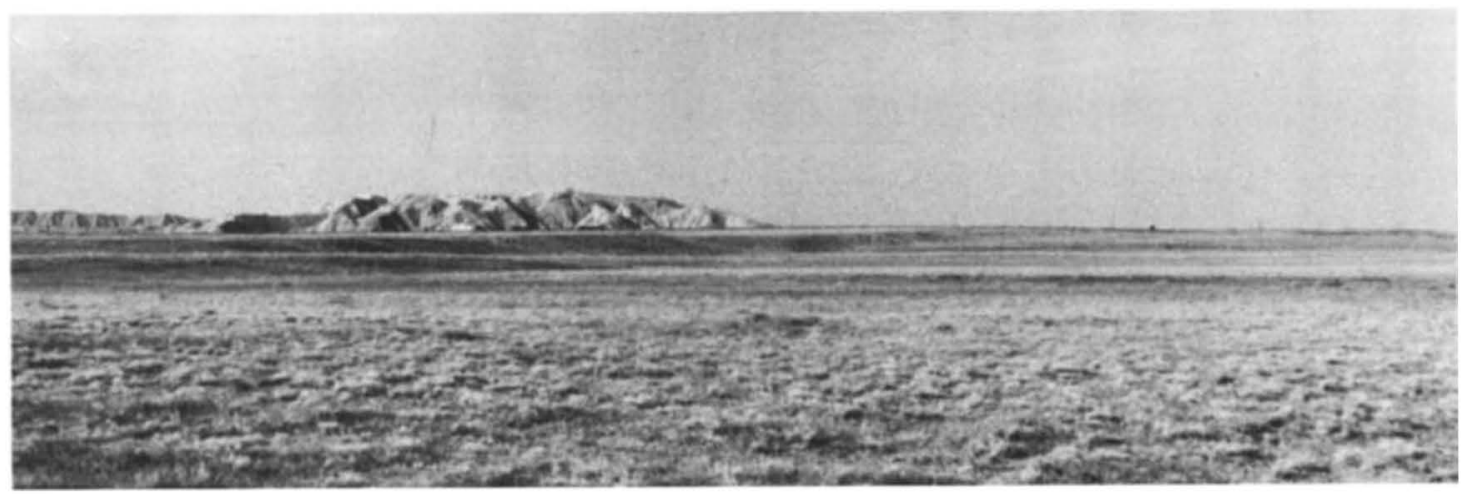

Fig. 23. Southeast looking view of scarps at site DSZ. South dipping limb of anticline A7 is visible in background.

December 23, 1906, Manas earthquake. This great shock may have caused $1 \pm 0.3 \mathrm{~m}$ of slip at the surface as well as incremental folding, but probably had a mean slip of $3.5 \pm 2 \mathrm{~m}$ at depth. Assuming that the thrust only breaks during characteristic earthquakes similar to the last 1906 event, the recurrence time of such earthquakes would be $850 \pm 380$ years. Our data do not allow discussion of a more complex seismic cycle.

\section{PRESENT DAY RATE OF SHORTENING, AND FINITE AMOUNT OF SHORTENING ACROSS THE TIEN SHAN SOUTH OF MANAS}

\section{Rate of Shortening Across the Boro Horo Piedmont}

At the surface, the Holocene vertical throw rate along the Tugulu-Dushanzi thrust, which is the principal active fault along the Boro Horo piedmont between $85^{\circ} \mathrm{E}$ and $87^{\circ} \mathrm{E}$, appears to have a uniform value of $1.0 \pm 0.3 \mathrm{~mm} / \mathrm{yr}$.

The relatively steep dip angles of the various ramp segments that compose this thrust $\left(55 \pm 5^{\circ}\right)$ imply a Holocene slip rate of $1.25 \pm 0.5 \mathrm{~mm} / \mathrm{yr}$. Since the ramps appear to root into a flat decollement (Figures $3 a$ and 26), this rate may be taken to represent a lower bound of the rate of slip on that decollement. Thus there ought to be at least $1.25 \pm 0.5 \mathrm{~mm} / \mathrm{yr}$ of shortening across the piedmont. As with seismic slip during the 1906 Manas earthquake, more shortening than that inferred from surface offsets along the thrust trace probably takes place. For instance, kinematic compatibility at ramp flat bends requires shortening either by slip on other faults or by folding. Additional shortening is clearly absorbed in the gentle folds (A5, A9) north of some segments of the Tugulu-Dushanzi thrust (Plate 2 and Figure 21). 


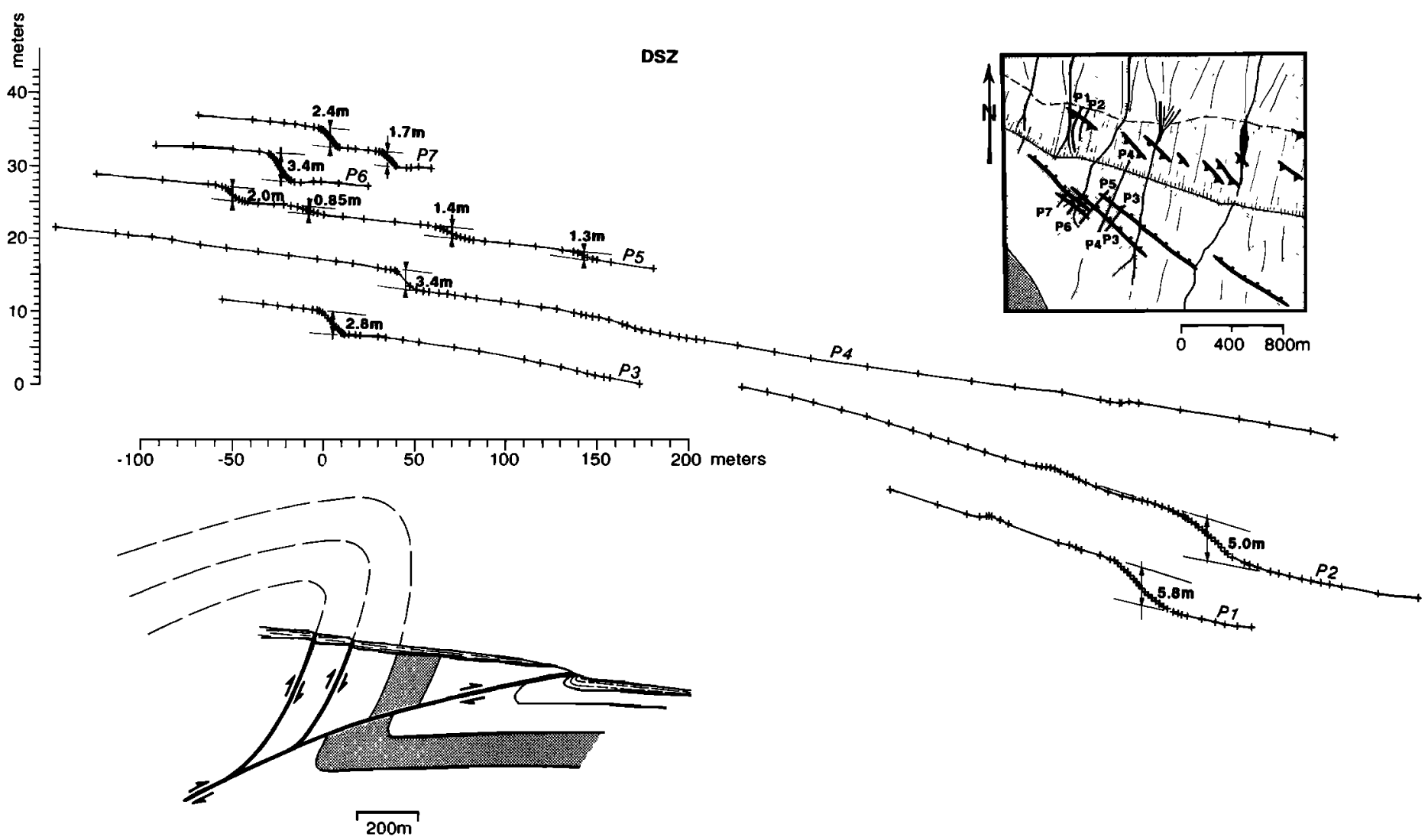

Fig. 24. Profiles transverse to thrust scarps at site DSZ. Note multiple offsets of fan surface. Sketch map (insert, top right) of box in Figure 22 shows location of profiles. Diagram (insert, bottom left) shows inferred attitudes of faults relative to geological structure.

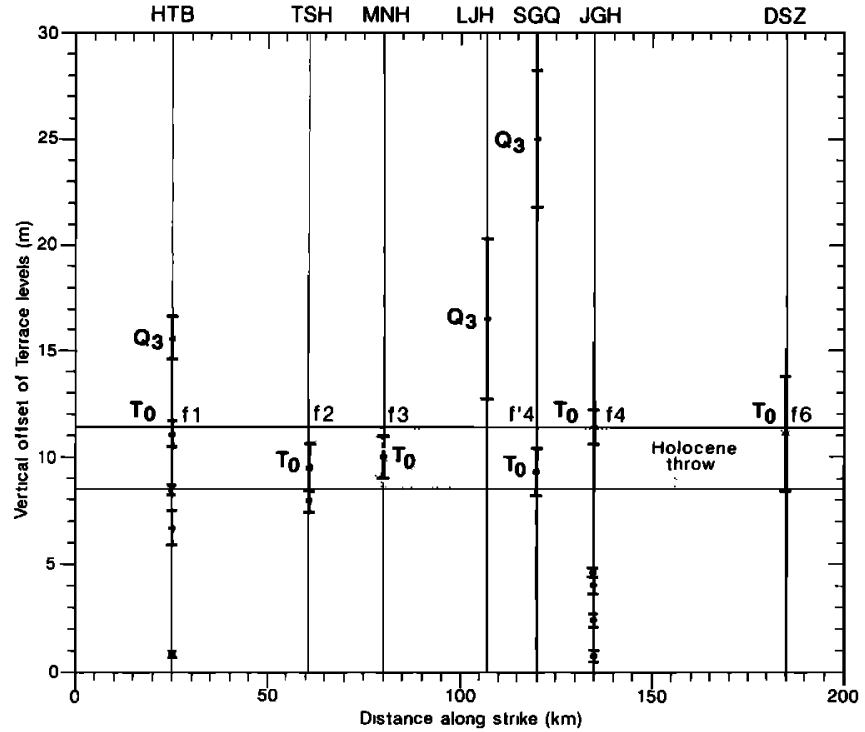

Fig. 25a. Summary of measured offsets of Late Quaternary surface (Q3), and of rivercut terrace levels (Holocene) along Hutubi-Dushanzi thrust zone. Levels T0-T4 and Q3 do not necessarily correlate from site to site and were defined independently at each site. Shaded band shows the range of offsets recorded by the uppermost terrace at each site (T0), which is inferred to mark the onset of Holocene.

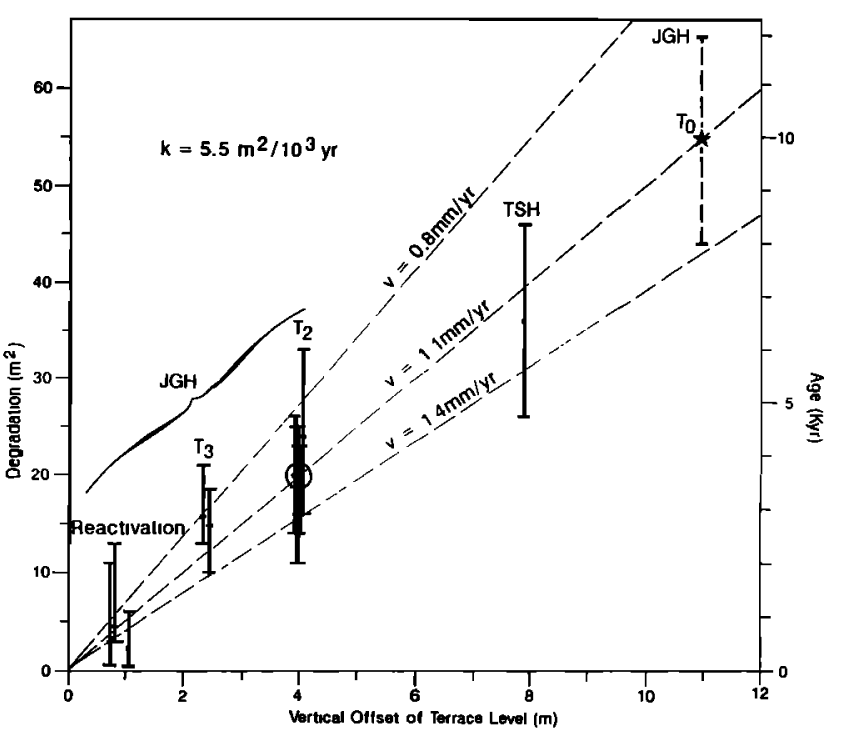

Fig. 25b. Degradation coefficients plotted as function of offsets by thrust at sites JGH and TSH. Terraces with greater offsets correspond to greater degradation coefficients. Linear relationship between offsets and coefficients implies constant throw and degradation rates. Mass diffusivity of $5.5 \pm 2.5 \mathrm{~m}^{2} / \mathrm{kyr}$ is inferred from constant throw rate of $1.1 \pm 0.3 \mathrm{~mm} / \mathrm{yr}$ between abandonment of T0 $(10 \pm 2 \mathrm{ka}, \mathrm{star})$ and $\mathrm{T} 2$ at site JGH and from degradation coefficient related to $T 2\left(19.5 \pm 3 \mathrm{~m}^{2}\right.$, open circle). 
TABLE 4. Values of Vertical Throw Rates Along Thrust and of Rates of Incision of Rivers Across the $10 \pm 2$ ka Fans

\begin{tabular}{ccc}
\hline Site & Throw Rale, $\mathrm{mm} / \mathrm{yr}$ & Incision Rate, $\mathrm{mm} / \mathrm{yr}$ \\
\hline HTB & $0.85 \pm 0.19$ & $\approx 5$ \\
& $1.11 \pm 0.28$ & \\
TSH & $0.95 \pm 0.30$ & \\
MNH & $1.0 \pm 0.30$ & \\
SGQ & $0.93 \pm 0.30$ & $\approx 5$ \\
JGH & $1.14 \pm 0.31$ & \\
DSZ & $1.10 \pm 0.49$ & \\
\hline
\end{tabular}

Assuming that the ratio between the Holocene surface slip rate and the maximum Holocene slip rate at depth is the same as that inferred between the surface slip and the maximum slip at depth for the 1906 earthquake $(\approx 5.5 \mathrm{~m})$, a maximum shortening rate of $4.9 \pm 1.4 \mathrm{~mm} / \mathrm{yr}$ is obtained at depth under the Boro Horo range. We conclude that a mean Holocene shortening rate of $3.0 \pm 1.5 \mathrm{~mm} / \mathrm{yr}, 2-3$ times the minimum value derived from the long-term surface offsets along the Tugulu-Dushanzi thrust $(1.25 \pm 0.5 \mathrm{~mm} / \mathrm{yr})$ is the most plausible. With a crustal ramp dipping $45^{\circ}$ under the Boro Horo range, this would also be the rate of uplift of rocks of that range relative to the southern Dzungarian basement.

\section{Finite Shortening North of the Boro Horo Range}

The three-dimensional diagram and the sections of Figure 26 show mechanisms of Cenozoic overthrusting at the scale of the upper crust along the Boro Horo range that are compatible with the evidence summarized in Figures 2 and 3 and Plates 1, 2, and 3. The range as a whole is inferred to have formed as a crustal ramp anticline. Underthrusting of the Dzungarian basement has resulted in decollement and folding of the sedimentary cover. West of Urumqi the main active decollement ramps to the surface about $30 \mathrm{~km}$ north of the range front along the TuguluDushanzi fold and thrust belt. Two different hand-balanced cross sections illustrating such a large-scale mechanism of overthrusting are shown in Figure 26a. Both have been constructed assuming detachment and folding of the sedimentary cover overlying a flexed, monoclinal Dzungarian basement that underthrusts the Tien Shan.

The top section is based on the assumption that Cenozoic tectonics involved thin-skinned deformation of the foreland with major prograding thrust ramps at and near the range front and three principal decollement levels (Upper Permian, base of Upper Cretaceous and base of Neogene). Such a section is consistent with the thrusts observed at the foot of the range west of She Chang (Plate 3). The fact that the Jurassic and Lower Cretaceous crop out at the surface in large anticlines north of these thrusts (e.g., San Ge Quen section, Plate 3, and section south of HTB, Plate $2 b$ ) is accounted for by antiformal stacking. This section shows $30-35 \mathrm{~km}$ of Cenozoic shortening and maximizes the size of the sedimentary wedge that is overthrust by the Boro Horo range. The existence of such a thick wedge was inferred from travel times delays by Nelson et al. [1987].

The bottom section in Figure $26 a$ is simpler. It is based on the assumption that the major thrust under the Boro Horo range remained blind and flattened into one main decollement at the base of the upper Cretaceous since the onset of shortening. It implies only $10-15 \mathrm{~km}$ of shortening.

Although these two sections are the simplest compatible with our observations, they are not unique. Moreover, since we were not granted access to the range front in all the valleys, we cannot decide unambiguously whether a Cenozoic, now inactive, ramp and an antiformal stack exist everywhere along the range, and choose between such sections. Note, however, that the top section accounts best for the progressive development of a flexural foreland basin. An amount of shortening of $30 \mathrm{~km}$ could have been reached in $10 \mathrm{~m} . \mathrm{y}$. at the rate of $3 \mathrm{~mm} / \mathrm{yr}$. Placing the reactivation of the Dzungarian Tien Shan at $23 \mathrm{Ma}$, in keeping with the bulk of the sediment in the flexural foreland basin being Neogene and Quaternary, would yield $35 \mathrm{~km}$ of shortening at the minimum rate $(1.5 \mathrm{~mm} / \mathrm{yr})$ inferred above.

\section{Shortening Across the Whole Tien Shan South of Manas}

Basement underthrusting with decollement and folding of the sedimentary cover appears to occur also on the south side of the Tien Shan, along the edge of the Tarim basin [e.g., Tapponnier and Molnar, 1979; Nelson et al., 1987; Chen et al., 1985].

The cross section shown in Figure 27 (AA', Figure 2), which passes near Manas, strikes roughly perpendicular to the southdipping Tugulu-Dushanzi thrust, to the different ranges that compose the $220-\mathrm{km}$-wide Tien Shan belt and to the north dipping thrust that bounds the belt between Korla and Kucha along the Tarim (Figures 1 and 2). Hypocenters of all the earthquakes located less than $100 \mathrm{~km}$ on either side of that section on Figure 2 are projected on the vertical section plane. The preferred nodal planes of known fault plane solutions are also shown. Except for the shock of March 3, 1983, most earthquakes appear to be located within the underthrust crust on either sides of the belt. The seismicity in Figures 2 and 27 thus implies that most of the present-day shortening occurs on the thrusts that bound the Tien Shan belt to the south and north and that these two thrusts are similarly active. Assuming negligible seismicity within the belt and similar seismic strain rates along both thrusts would yield a shortening rate of $6 \pm 3 \mathrm{~mm} / \mathrm{yr}$ across section AA'. Assuming only small-scale Tertiary thrusting inside the belt and comparable amounts of finite shortening, as implied by the comparable topography of the range fronts (Figure 27), along the two bounding thrusts would imply a finite shortening of $60 \mathrm{~km}$ across that particular section. Since a few recent folds and thrusts are visible on satellite images within the Tien Shan, especially east of $\mathrm{AA}^{\prime}$, it is likely that the seismic shortening rate at $\approx 85^{\circ} \mathrm{N}$ is somewhat greater than $6 \pm 3 \mathrm{~mm} / \mathrm{yr}$. The shortening required to create a $200-\mathrm{km}$-wide zone of thickened crust is probably significantly greater than $60 \mathrm{~km}$. Thus the estimated shortening rate of $6 \pm 3 \mathrm{~mm} / \mathrm{yr}$ and cumulative shortening of $60 \mathrm{~km}$ should both be considered lower bounds

The amount of crustal shortening responsible for the present high topography and absorbed by crustal thickening across the whole Tien Shan along section $\mathrm{AA}^{\prime}$ may be estimated by balancing the crustal area under the belt. We assume decollement of the sedimentary covers in the basins flanking the belt. Neglecting erosion, on sections such as those in Figure 28, this shortening would be given by

$$
S h_{r}=\frac{A r_{1}-A r_{2}}{H 0},
$$

where $A_{r 2}$ and $A_{r 1}$ are the present-day and initial respectively, crustal areas under the belt, and $\mathrm{HO}$ is the thickness of the crust under the basins without the sediment.

Erosion moves surface rocks away from a mountain belt. If rivers born in a belt do not reach the sea, the material removed and transported by erosion ends up in the form of sediments only. This is the case in the Tien Shan, which formed far into the interior of the Asian continent. Knowledge of the amount of crust removed by erosion in the mountain belt and deposited as 

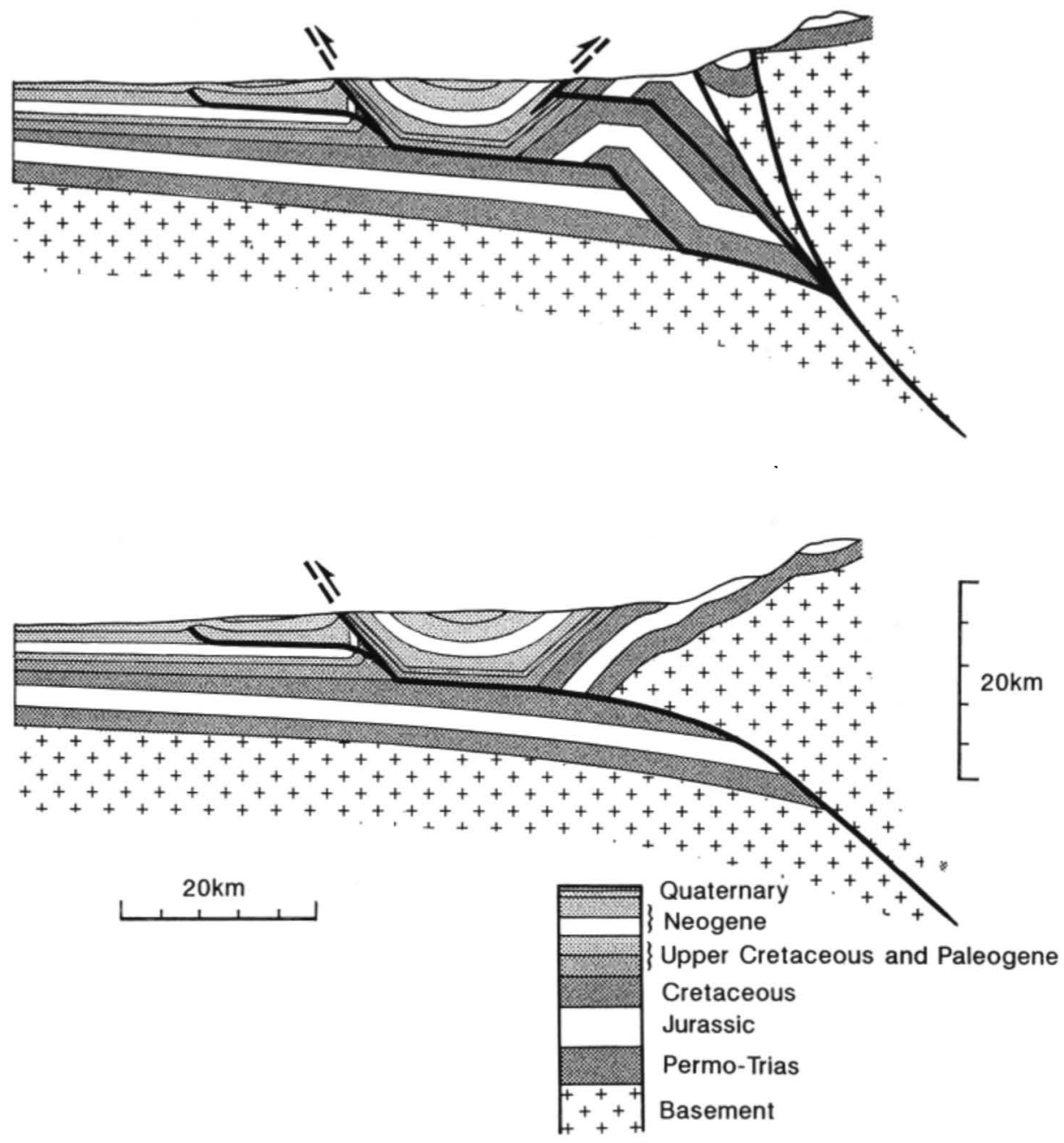

Fig. 26a. Block diagram showing mechanism of large-scale overthrusting along north edge of Dzungarian Tien Shan. The 4500 to 5500-m-high mountain ranges formed as crustal ramp anticlines. West of Urumqi, flat detachement under particularly thick foreland sediments ramps to surface only $30 \mathrm{~km}$ north of range front along Hutubi-Dushanzi fold and thrust belt.

sediments permits correcting for the effect of erosion. Assuming cylindrical geometry and taking into account sediment decompaction, this correction is

$$
S h_{\mathrm{sed}}=\frac{r_{\mathrm{sed}} A_{\mathrm{sed}}}{r_{c} \mathrm{H} 0}
$$

$A_{\text {sed }}$ being the cross sectional area of the sediments deposited in the adjacent basins during mountain building, and $r_{\text {sed }}$ and $r_{c}$ being the sediment and crustal densities respectively. The amount of shortening during intracontinental mountain building with erosion is thus given by

$$
S h=\frac{A r_{1}-A r_{2}}{\mathrm{H} 0}+\frac{r_{\text {sed }} A_{\text {sed }}}{r_{c} \mathrm{HO}} \text {. }
$$

To estimate shortening thus requires information on the topography, on the geometry of the Moho across the belt, and on the amount of sediments in the basins in the initial and present states, as well as on the densities of the crust and sediments.

Three possible geometries of the Moho are drawn on Figure 27. Densities are taken to be 3.3 for the upper mantle, 2.8 for the crust, and 2.6 for sediments in the Tarim [Burov et al.,
1990] as well as in the Dzungarian basins. The average elevation being $\approx 2800 \mathrm{~m}$ across the $220 \mathrm{~km}$ wide belt on $\mathrm{AA}^{\prime}$, Moho depths, computed assuming local isostasic compensation of the topography (short dashed line), or regional compensation by flexure of a continuous elastic plate with a flexural rigidity $D=4.7 \times 10^{22} \mathrm{~N} \mathrm{~m}$ (or an elastic thickness of $20 \mathrm{~km}$, with a Young's modulus $E=8 \times 10^{10} \mathrm{~N} / \mathrm{m}^{2}$ (continuous line), are not very different $(\mathrm{H} 2 \approx 53 \mathrm{~km})$ and are essentially consistent with the Bouguer gravity profile shown above the section. This implies that the belt is very nearly locally compensated. The long dashed line corresponding to flexure of a continuous plate with a flexural rigidity $D=30 \times 10^{23} \mathrm{~N}$ m (or an elastic thickness of $\approx 80 \mathrm{~km}$ ) would imply that the belt is far from isostatic compensation, which is clearly not compatible with the gravity profile. Hence, for our purpose of estimating crustal shortening, we take the Moho geometry to be consistent with local compensation. The corresponding crustal area under the belt is thus $A_{\mathrm{r} 2}=12 \times 10^{3} \mathrm{~km}^{2}$.

Parameters defining the initial geometry of the crust in the Tien Shan and adjacent regions before the onset of Cenozoic reactivation are more difficult to assess. As summarized in the first section of this paper, the Upper Cretaceous and Lower 


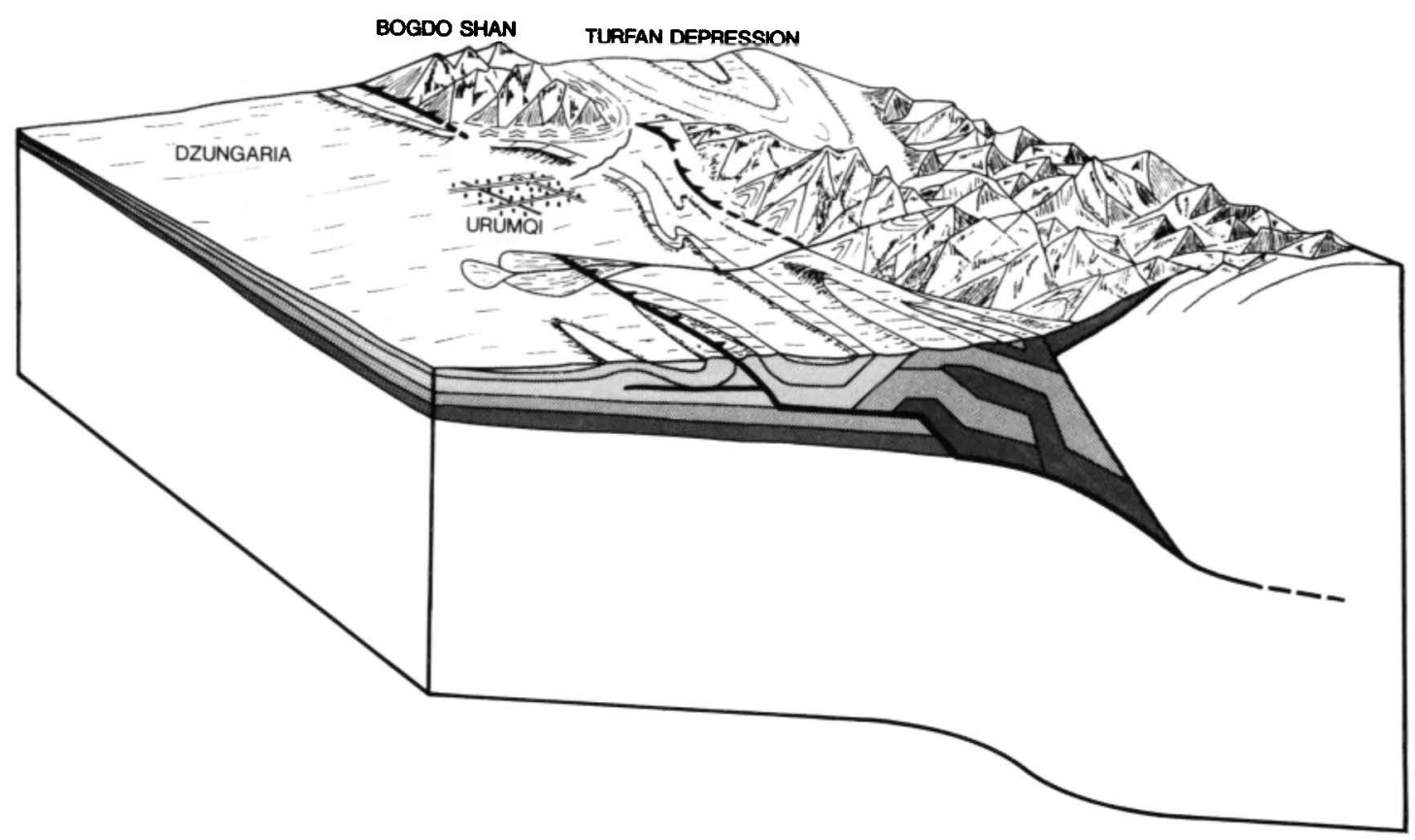

Fig. 26b. Hand-balanced cross sections of north edge and piedmont of Boro Horo range. Top section, based on observations near the range on San Ge Quen section (Plate 3) and drawn assuming thin-skinned tectonics in foreland, foreland ramp migration and three main detachment levels, implies $30-35 \mathrm{~km}$ of Cenozoic shortening (see text). Bottom section, based on observations near the range on Linjia He section (Plate 3) and drawn assuming single basement ramp flattening into one main detachement level, implies only $15-20 \mathrm{~km}$ of shortening.

TABLE 5. Values of Moment $\left(M_{0}\right)$ and of Magnitude $\left(M_{W}\right)$ of the 1906, Manas Earthquake for Different Ruptures Parameters Based on Fault Geometry in Figure 26

\begin{tabular}{ccccc}
\hline$u, \mathrm{~m}$ & $\mathrm{~W}, \mathrm{~km}$ & $L, \mathrm{~km}$ & $M_{0}, 10^{20} \mathrm{~N} . \mathrm{m}$ & $M_{\mathrm{W}}$ \\
\hline 0.7 & 65 & 100 & 1.5 & 7.4 \\
1 & 75 & 150 & 3.7 & 7.7 \\
1.3 & 85 & 200 & 7.3 & 7.9 \\
1.5 & 75 & 150 & 5.6 & 7.8 \\
2 & 75 & 150 & 7.4 & 7.9 \\
3 & 75 & 150 & 11.1 & 8.0 \\
4 & 75 & 150 & 14.9 & 8.1 \\
5 & 75 & 150 & 18.6 & 8.2 \\
5.5 & 75 & 150 & 20.4 & 8.2 \\
6 & 75 & 150 & 22.3 & 8.2 \\
\hline
\end{tabular}

$u$ is seismic slip, $W$ is fault width, and $L$ is fault length.

Tertiary appear to have been particularly quiet periods from a tectonic point of view. They were also periods of widespread deposition of relatively uniform and moderate thicknesses of mature continental sediments [Hendrix et al., 1992]. Although crustal thickening continued into the Permian, the Jurassic appears to have been a period of localized, mostly normal and strike-slip faulting. The tectonic history and geological record thus suggest a rather smooth morphology, with no great elevation differences and rather low elevation in the early Tertiary. Apparently, there were no large residual mountains. Nor were there large subsident basins floored by thinned crust. Present average elevations and Moho depths in the Tarim and in Dzungaria (two parts of central Asia that have so far escaped Tertiary tectonic reactivation) are about $900-1100 \mathrm{~m}$ and 400 $500 \mathrm{~m}$ and 42 and $37 \mathrm{~km}$, respectively [ $\mathrm{Ma}, 1987]$. The average elevation and Moho depth under the Tien Shan in the early Cenozoic were thus probably between 100 and $1100 \mathrm{~m}$ and 35 and $42 \mathrm{~km}$, respectively. Moreover, whether in the Tarim or in Dzungaria, the continental basement in the flexural basins adjacent to the Tien Shan is only about $35 \mathrm{~km}$ thick under 5-12 km thick sedimentary wedges. Reasonable values of initial crustal thicknesses under the belt (H1) and under the adjacent Tarim and Dzungarian basins (HO) thus appear to be between 35 and $42 \mathrm{~km}$ (Figure 28).

On section $A A^{\prime}$ in Dzungaria, the cross sectional area of the sediments deposited in the flexural foreland basin during the Cenozoic orogeny (post-Cretaceous, Plate 1 , inset) is $A_{\text {sed }}(\mathrm{Dz})_{\mathrm{M}}=950 \mathrm{~km}^{2}$. This is a maximum value because $\mathrm{AA}^{\prime}$ crosses the basin where it is deepest. From the isopach map of Figure 2, the average cross-sectional area along the $300-\mathrm{km}-$ long piedmont would be at least $A_{\text {sed }}(D z)_{m}=500 \mathrm{~km}^{2}$, since at least half of the infill of the basin is of Cenozoic age. In the Tarim basin, the total volume of sediments overlying the Paleozoic basement is $\approx 2.4 \times 10^{6} \mathrm{~km}^{3}$ [Chen et al., 1985]. From the sediment isopachs map of Bally et al. [1986], the volume of the Cenozoic sediments resulting from erosion of the rising mountains surrounding the basin is about two thirds of that total, $\approx 1.7 \times 10^{6} \mathrm{~km}^{3}$. These sediments come mostly from the Tien Shan and Kunlun mountain belts whose lengths and elevations are of the same order. Taking the contribution of either belt to the total Cenozoic infilling of the Tarim to be about the same would imply that $\approx 8.5 \times 10^{5} \mathrm{~km}^{3}$ of sediments were supplied by erosion of the Tien Shan during mountain building. The length of the Tarim foreland basin being about $1000 \mathrm{~km}$ (between $75^{\circ}$ and $88^{\circ} \mathrm{E}$ ), the average cross-sectional area of Cenozoic sediments in that basin would be $A_{\text {sed }}(T a)=850 \mathrm{~km}^{2}$, a value comparable to $A_{\text {sed }}(\mathrm{Dz})$. Taking the amount of sediments to be roughly proportionnal to the width of mountain belt eroded implies that it increases by a factor of $\approx 2$ from $88^{\circ}$ to $75^{\circ} \mathrm{E}$, as the width of the Tien Shan increases from about 200 to $400 \mathrm{~km}$. Hence $A_{\text {sed }}(\mathrm{Ta})$ would vary between 560 and $1140 \mathrm{~km}^{2}$ 

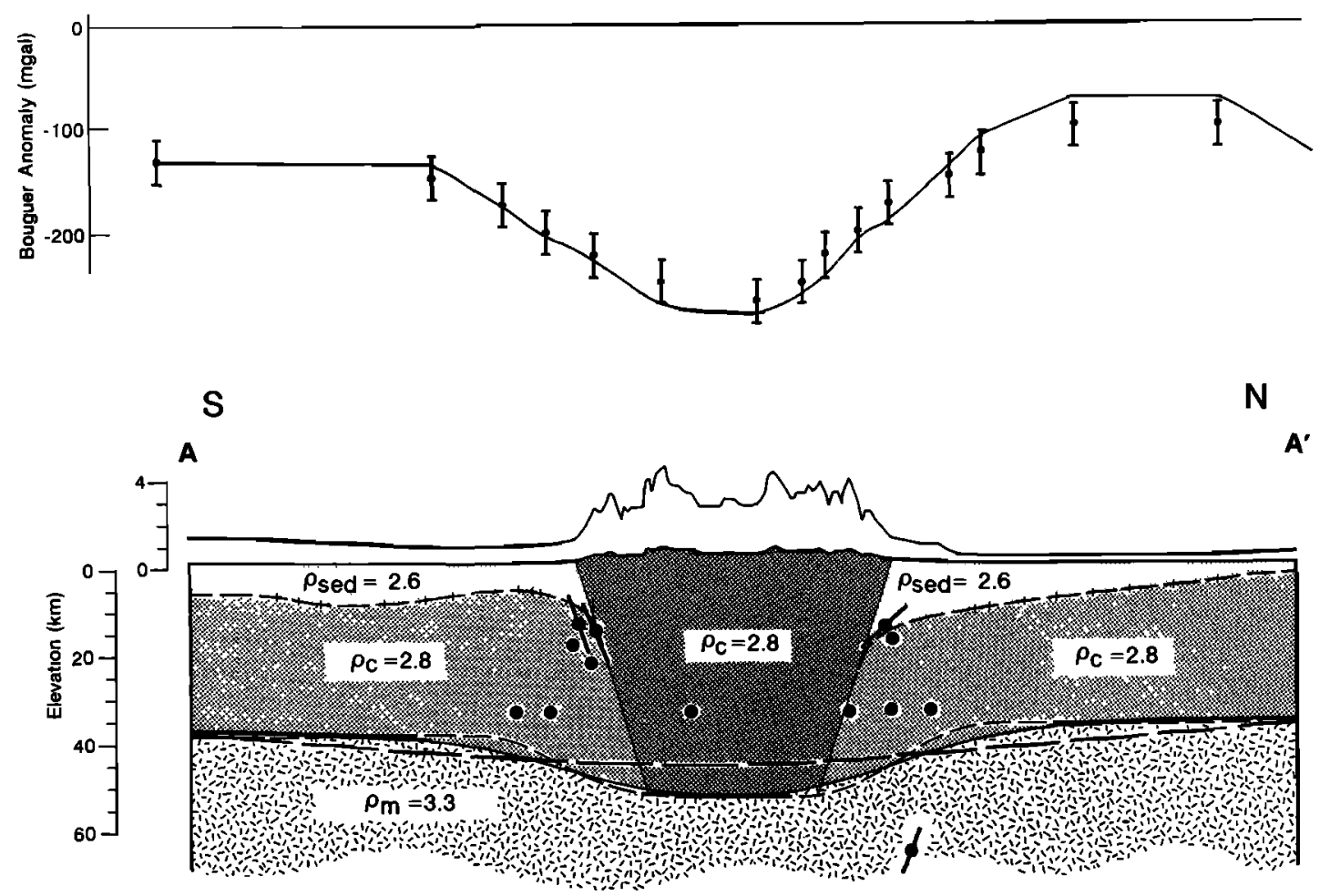

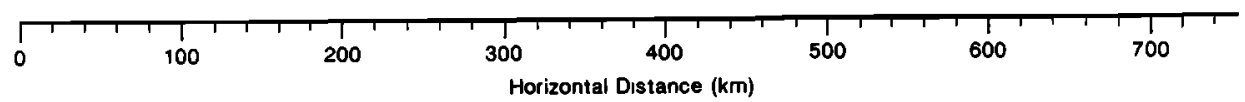

Fig. 27. Crustal section model across eastern Tien Shan (AA', see location in Fig.s 1 and 2). Topography is from Operational Navigational charts (O.N.C.) [Defense Mapping Agency, 1982]. Seismicity (open circles) and fault plane solutions (solid circles with bar representing attitude of most likely fault plane) from Figure 2. Depth of basement is from Chen et al. [1985]. Numbers are densities used to compute Moho depth assuming isostatic compensation. Short dashed line represents Moho of continuous plate with no flexural rigidity. Continuous line (long dashed line) represents Moho of flexed continuous plate with elastic thickness of $20 \mathrm{~km}(80 \mathrm{~km})$. Dots with error bars above section are values of Bouguer gravity anomalies along profile (from $1^{\circ} \times 1^{\circ}$ Bouguer gravity anomaly map of eastem Tien Shan and Altai region [Ding G., 1985, P. 166D. Continuous line is two-dimensional gravity fit assuming local compensation of topography.

Reasonable values for either $A_{\text {sed }}(\mathrm{Dz})$ or $A_{\text {sed }}(\mathrm{Ta})$ across section $\mathrm{AA}^{\prime}$ thus appear to be of the order of $600 \mathrm{~km}^{2}$.

With extreme initial thickness values of $\mathrm{HO}=\mathrm{H1}=35 \mathrm{~km}$, $\mathrm{HO}=35 \mathrm{~km}$, and $\mathrm{H1}=42 \mathrm{~km}$ or $\mathrm{HO}=\mathrm{H} 1=42 \mathrm{~km},(8)$ yields Cenozoic shortening values across the Tien Shan south of Manas of 154,110 , or $97 \mathrm{~km}$, respectively, of which $31 \mathrm{~km}$ (between 20 and $30 \%$ ) correspond to the erosion term (Table 6). Thus, at this longitude, mountain building in the Tien Shan would have absorbed $124 \pm 30 \mathrm{~km}$ of Cenozoic convergence between Tarim and Dzungaria. This is about twice the amount of finite shortening estimated to have been absorbed by the thrusts bounding the belt since the onset of Cenozoic reactivation. If $124 \pm 30 \mathrm{~km}$ of shortening had been absorbed at a rate of $6 \pm 3 \mathrm{~mm} / \mathrm{yr}$ across the Tien Shan south of Manas, reactivation would have started around $21(+30 /-10) \mathrm{Ma}$, in keeping with the Neogene-Quaternary sediment fill of the flexural foreland basins.

\section{Heterogeneous Shortening Across the Tien Shan and Clockwise Rotation of the Tarim Relative to Dzungaria and Kazakhstan}

At the largest scale in map view (Figure 1), the Tien Shan belt is wedge-shaped. Its width increases towards the west, reaching about $400 \mathrm{~km}$ north of Kashgar, at $76^{\circ} \mathrm{E}$ (Figure 1). It vanishes into the Gobi desert near $96^{\circ} \mathrm{E}$, about $1700 \mathrm{~km}$ eastwards along strike (Figure 1). In fact, taking the $2000 \mathrm{~m}$ elevation contour as defining the limit of the mountainous relief, the northern and southern borders of the Tien Shan may be fitted with two great circles ( $C$ and $\mathrm{C}_{0}$ in Figure 29) that intersect east of Hami (point $\mathrm{P}$, at $95.7^{\circ} \mathrm{E}, 43.5^{\circ} \mathrm{N}$, Figure 29, see also Chen et al.,[1991] and make an angle of $12^{\circ}$. This geometry indicates that there has been more crustal thickening and shortening in the westem than in the eastern Tien Shan. Moreover, the width of the mountain belt, hence presumably the amount of shortening, increases regularly westwards with distance from $P$. This implies that concurrent with Cenozoic mountain building in the Tien Shan belt, the Tarim block has rotated clockwise relative to regions located north of the belt, in particular Kazakhstan and Dzungaria, roughly about $P$ [Avouac et al., 1990]. The Tarbagatay mountains, which separate Dzungaria from Kazakhstan, are only about $50 \mathrm{~km}$ wide, with maximum elevations generally between 2500 and $3000 \mathrm{~m}$ (Figure 1). They are modest ranges by Central Asian standards. Recent and active strike-slip faults south of the Tarbagatay, including the Dzungar fault, have small lengths. It thus seems likely that the amount of Cenozoic movement, including rotation, between Dzungaria and Kazakhstan has been small. This inference is supported by the small amount of post-Mesozoic counter clockwise paleomagnetic rotation $\left(2.6 \pm 4.5^{\circ}\right)$ found between Dzungaria and Siberia, which is attached to Kazakhstan [Chen et 
al., 1991]. To the first order, it is therefore reasonable to assume that Dzungaria and Kazakhstan form a relatively stable block, that has not moved much relative to Siberia.

The inference that the Tarim has rotated clockwise relative to regions north of it may be tested quantitatively, and the amount of rotation determined by constraining the E-W gradient of

\section{INITIAL STATE}

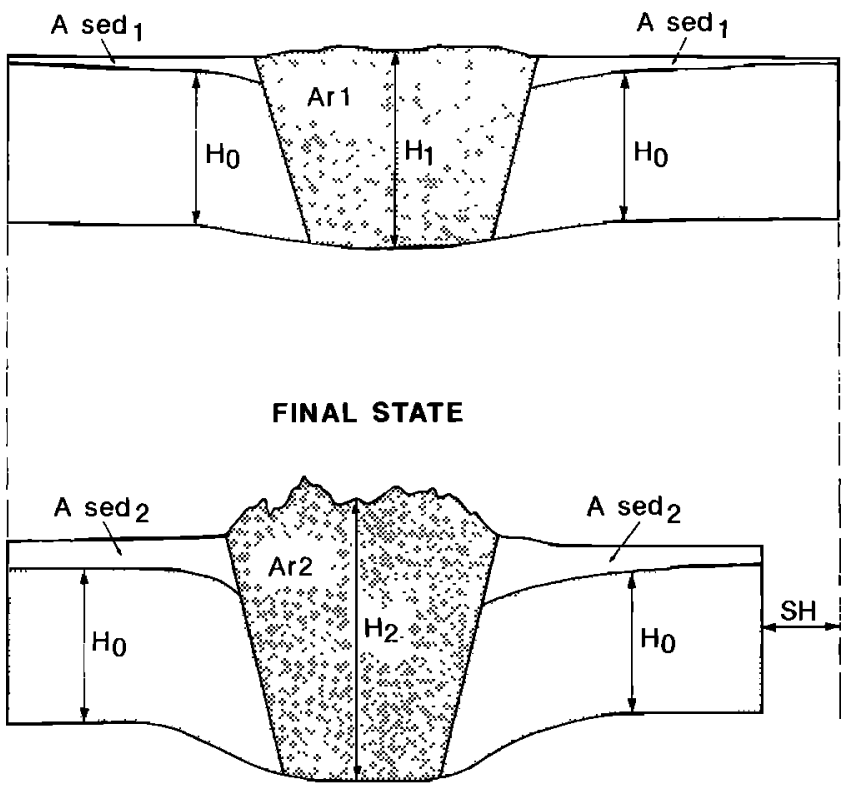

Fig. 28. Estimation of crustal shortening from crustal section. Information on geometry of Moho in final and initial state, as well as on amount of crust eroded during mountain building, is required. $\mathrm{A}_{\mathrm{f}}$ is crustal area under range in initial state; $A_{22}$ is final state. $H 0$ is thickness of crust in basins under detached sediments. $\mathrm{Hl}$ is initial crustal thickness under range. $A_{\text {sed1 }}$, and $A_{\text {sed2 } 2}$ are initial and final, respectively, cross-sectional areas of sediments in basins. shortening. Following the approach used for section $\mathrm{AA}^{\prime}$ at $85.5^{\circ} \mathrm{E}$, we estimated amounts of Cenozoic crustal shortening on six N-S sections across the Tien Shan (at $76^{\circ} \mathrm{E}, 78^{\circ} \mathrm{E}$, section BB' in Figure $1,81^{\circ}, 84^{\circ}, 86^{\circ}$; and $93^{\circ}$, from west to east, Figure 30, Table 6). On all sections, amounts of shortening ignoring removal by erosion were tirst computed from equation (8). On section BB'for instance, north of Kashgar, the belt is about $380 \mathrm{~km}$ wide, and the thickened crustal area under the belt, about $20 \times 103 \mathrm{~km}^{2}$. In keeping with the three sets of initial thicknesses taken for section $\mathrm{AA}^{\prime}$, amounts of shortening ignoring removal by erosion across BB' are thus 191, 115, or $96 \mathrm{~km}$ (Table 6, Figure 30). Corrective terms corresponding to erosion were then calculated assuming the amounts of sediments deposited in the forelands north and south of the belt during mountain building to be roughly equal and proportional to belt width. For section BB', for instance, the cross sectional area of Cenozoic sediments in the Kazakhstan foreland is thus taken to be $A_{\text {sed }}(\mathrm{Ka}) \approx A_{\text {sed }}(\mathrm{Ta}) \approx 1100 \mathrm{~km}^{2}$, and the amount of additional shortening corresponding to erosion is $S h_{\text {sed }}=60 \mathrm{~km}$. Amounts of shortening corrected for erosion across BB' are thus 251,175 , or $155 \mathrm{~km}$, and the average shortening absorbed between Tarim and Kazakhstan north of Kashgar would be $203 \pm 50 \mathrm{~km}$.

TABLE 6. Crustal Shortening Values Along Sections Across Tien Shan at Different Longitudes

\begin{tabular}{ccccc}
\hline $\begin{array}{c}\text { Longitude, } \\
{ }^{\circ} \mathrm{E}\end{array}$ & $\begin{array}{c}\mathrm{H} 0=42 \mathrm{~km} \\
\mathrm{H} 1=42 \mathrm{~km}\end{array}$ & $\begin{array}{c}\mathrm{H} 1=35 \mathrm{~km} \\
\mathrm{H} 1=42 \mathrm{~km}\end{array}$ & $\begin{array}{c}H=35 \mathrm{~km} \\
\mathrm{H} 1=35 \mathrm{~km}\end{array}$ & Erosion, $\mathrm{km}$ \\
\hline $76\left(\mathrm{BB}^{\prime}\right)$ & 96 & 115 & 191 & 60 \\
78 & 107 & 128 & 204 & 54 \\
81 & 74 & 89 & 171 & 44.5 \\
84 & 54 & 65 & 109 & 35.5 \\
$\approx 85.5\left(\mathrm{AA}^{\prime}\right)$ & 66 & 79 & 123 & 31 \\
86 & 38 & 45.5 & 66 & 29 \\
93 & 17 & 20.5 & 48 & 7.2 \\
\end{tabular}

All sections strike N-S, except $\mathrm{AA}^{\prime}\left(\mathrm{N} 20^{\circ} \mathrm{E}\right)$. Three values for each section (see plot as a function of longitude in Figure 30 ) correspond to three sets of initial crustal thicknesses discussed in text. Erosion contribution is specified in last column.

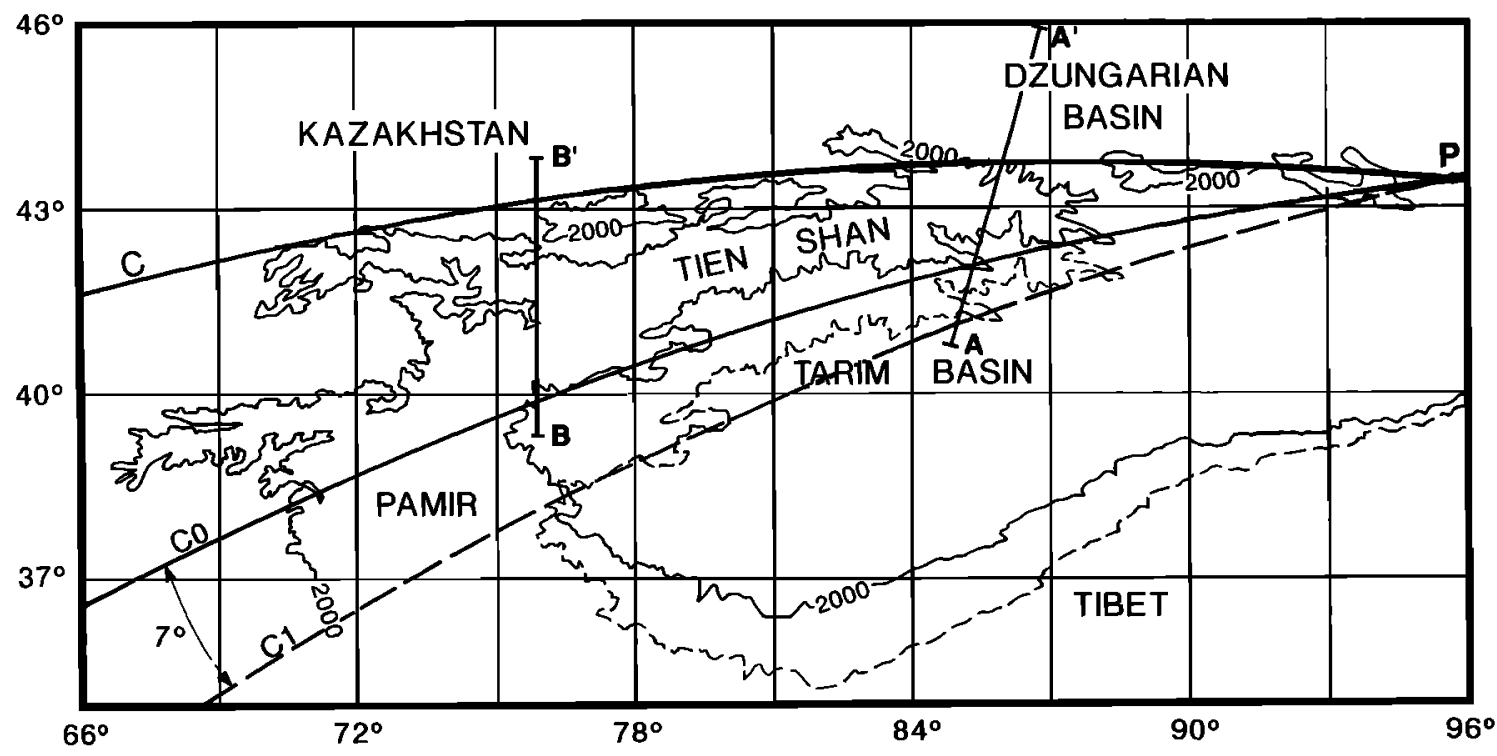

Fig. 29. Westward increase in width of Tien Shan reflects clockwise rotation of Tarim relative to Dzungaria and Kazakhstan. Tien Shan relief is outlined by $2000 \mathrm{~m}$ elevation contour, which can be fitted with great circles $\mathrm{C}$ and $\mathrm{C}_{0}$ intersecting at point $P$. Dashed line shows position of the $2000 \mathrm{~m}$ elevation contour line rotated $\mathrm{CCW}$ by $7^{\circ}$ around pole $\mathrm{P}$ (see text for discussion). Values of shortening across $\mathbf{A A}^{\prime}$ and $\mathrm{BB}^{\prime}$ corresponding to different rotation angles about $\mathbf{P}$ are listed in Table 4 . 


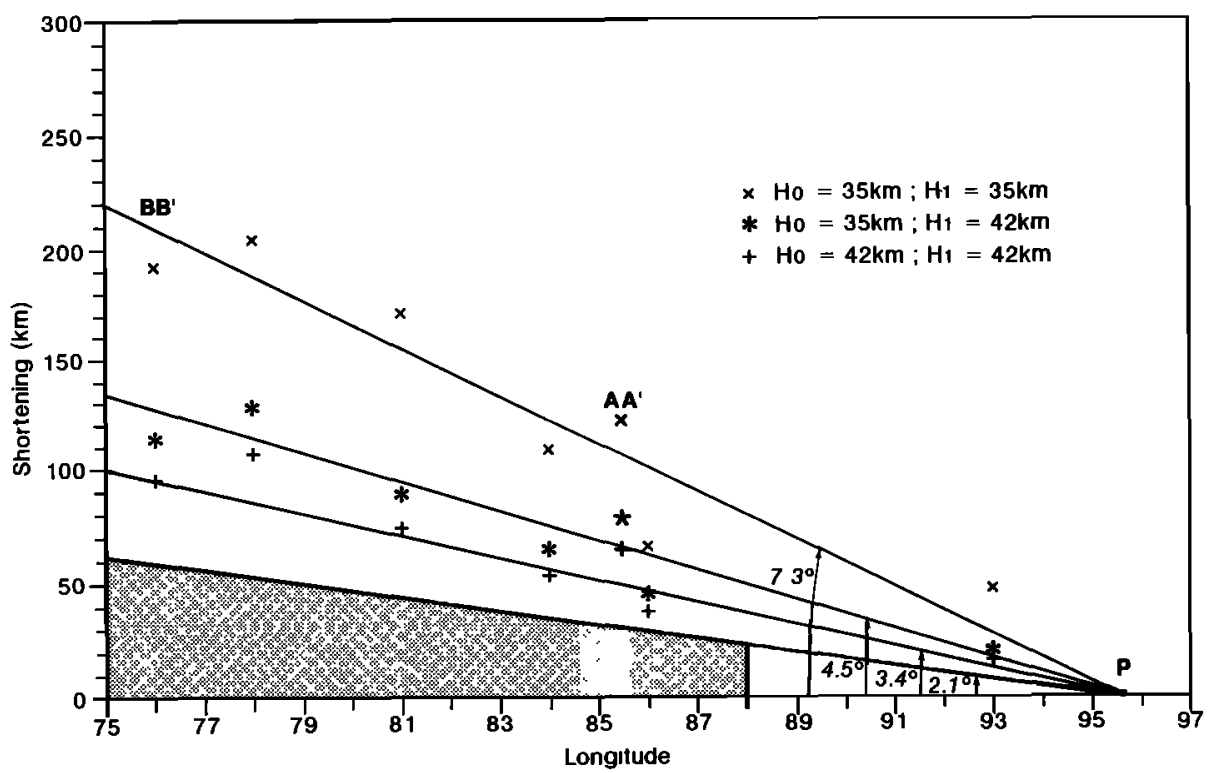

Fig. 30. Values of shortening on $\mathrm{N}-\mathrm{S}$ serial sections across Tien Shan, deduced from local isostatic compensation of the topography, for different initial geometries. Bold symbols are for AA' that strikes $\mathbf{N} 20^{\circ} \mathbf{E}$. More shortening has occurred in western than eastern Tien Shan. Westward increase in shortening implies CW rotation of $3.4^{\circ}$ to $7.3^{\circ}$ of Tarim relative to Dzungaria and Kazakhstan. Dashed area corresponds to additional shortening if erosion is taken into account. If amount of eroded materials is proportional to mountain width, an additional $\mathrm{CW}$ rotation of $2.1^{\circ}$ is required.

Estimates of N-S shortening deduced from (8) across other sections are listed in Table 6 and plotted as a function of longitude on Figure 30 . For each section, three values corresponding to the three sets of initial thicknesses considered are given. For section $\mathrm{AA}^{\prime}$, that strikes $\mathrm{N} 20^{\circ} \mathrm{E}$, azimuthal correction yields components of N-S shortening of 116,74 , or $62 \mathrm{~km}$. The shaded area represents the additional shortening corresponding to erosion. The three values of N-S Cenozoic shortening decrease roughly linearly eastwards by about 10.8 , 7.1 , and $4.9 \mathrm{~km} /{ }^{\circ} \mathrm{E}$, respectively, to vanish in the vicinity of $P$. The correlation with belt width holds because average elevations across N-S sections vary only between 2500 and $2900 \mathrm{~m}$ along strike. Relative to the northern piedmont of the Tien Shan belt, these three shortening gradients imply clockwise, finite Cenozoic rotations of $7.3^{\circ}, 4.5^{\circ}$, or $3.4^{\circ}$ of the southern boundary of that belt about $P$. Erosion proportional to belt width would increase these angles by $2.1^{\circ}$, to $9.4^{\circ}, 6.6^{\circ}$, and $4.5^{\circ}$, respectively. In a reference frame fixed to Dzungaria and Kazakhstan, the westward increase of shortening across the Tien Shan is thus consistent with $7 \pm 2.5^{\circ}$ of clockwise rotation of the Tarim block (Figure 29). The short dashed line on Figure 29 shows the corresponding, reconstructed position of the $2000 \mathrm{~m}$ elevation contour that defines the rim of the Tarim Basin, before the onset of Cenozoic mountain building in the Tien Shan.

The angle of rotation derived from the crustal shortening gradient is consistent with the $8.6 \pm 8.7^{\circ}$ clockwise rotation of Tarim relative to Dzungaria deduced by Chen et al. [1991] from the paleomagnetic study of Cretaceous and Lower Tertiary red bed sites along the Dzungarian piedmont. The mean paleolatitude difference $\left(3.0 \pm 6.9^{\circ}\right.$ [Chen et al., 1991]) found between these sites and sites east of Aksu, south of the Tien Shan [ $\mathrm{Li}$ et al., 1988], on the other hand, could be taken to imply a north-south component of Tertiary shortening in the central Tien Shan of about $300 \mathrm{~km}$, an amount about $70 \%$ greater than that deduced from surface balancing of the crust assuming an initial thickness of $35 \mathrm{~km}$ (about $180 \pm 40 \mathrm{~km}$, Figure 30 and Table 6). This discrepancy might imply that the
Lower Tertiary crustal thickness of most of the Tien Shan and possibly of regions farther to the east in the Gobi was significantly less than $35 \mathrm{~km}$. Given both the absence of marine upper Mesozoic-Lower Tertiary sediments and the presence of numerous outcrops of Precambrian-Paleozoic metamorphic rocks east of $78^{\circ} \mathrm{E}$, and in view of the particularly large uncertainty on that paleolatitude difference, however, we find such a circumstance improbable.

Assuming that the Tarim block rotates roughly about $P$ relative to regions north of it (Figure 29), a shortening rate of $6 \pm 3 \mathrm{~mm} / \mathrm{yr}$ south of Manas would be consistent with a shortening rate of $12 \pm 6 \mathrm{~mm} / \mathrm{yr}$ north of Kashgar and with a clockwise rotation rate of $0.45 \pm 0.2^{\circ} / 10^{6}$ years. The corresponding average rate of shortening across the Tien Shan belt between 75 and $85^{\circ} \mathrm{E}$ would be $9 \pm 5 \mathrm{~mm} / \mathrm{yr}$. Such a value would not include internal strain within the belt, which seems small south of Manas. This rate is smaller than the 100 years average seismic shortening rate inferred for that belt $(13 \pm 7$ $\mathrm{mm} / \mathrm{yr}$ [Molnar and Deng, 1984]). A shortening rate of 12 $\mathrm{mm} / \mathrm{yr}$ in the Tien Shan north of Kashgar would represent two thirds of that inferred for regions located northwest of the southern Altyn Tagh fault $(19 \mathrm{~mm} / \mathrm{yr}$ across an area that includes the western Kunlun, Altyn Tagh, and Tien Shan mountains) from Holocene slip rates on faults in southern and northern Tibet [Armijo et al., 1989; Peltzer et al., 1989]. Taking the rate of rotation between the Tarim and Kazakhstan to have been constant and equal to $0.45 \pm 0.2 \% / 106$ years during the late Cenozoic, a $7 \pm 2.5^{\circ}$ angle of finite rotation between the two would imply that Tertiary mountain building in the Tien Shan began about $16(+22 /-9) \mathrm{Ma}$, in the middle Miocene, an age consistent with that of the most abundant sediments in flexural basins on either side.

\section{DISCUSSION AND IMPLICATIONS}

To our knowledge, the study of late Cenozoic and active shortening in the Tien Shan presented in this paper is the first to 
be based on detailed field measurements. For this reason, it provides a more accurate, quantitative picture of the geometry and kinematics of overthrusting along that range than was hitherto available. Clearly, because most of the geological and morphological evidence we discuss was collected west of Urumqi at the foot of the Boro Horo range, the results derived are robust in that region only. Nevertheless, they throw light on overthrusting processes along other parts of the Tien Shan where both the surface geology and topography are similar and may thus be used to constrain a large-scale tectonic model of the whole range. Moreover, because there have been few field studies of comparably active piedmonts at the foot of major continental mountain ranges, these results may serve to draw or corroborate simple inferences on the mechanics of crustal shortening along such ranges.

In terms of their recent structure and geometry, the two frontal ranges of the Dzungarian Tien Shan (Boro Horo and Bogdo Shan) appear to be large ramp anticlines, at the scale of the crust (Figure 27). This substantiates the old idea that high mountain ranges in various parts of Central Asia are crustal or "basement" folds [Hedin, 1922; Argand, 1924; Ulomov, 1974; Tapponnier and Molnar, 1979], an idea that is also gaining ground in other regions of active crustal shortening see for example,(Molnar and Lyon-Caen [1988], for a review of probable examples in the Himalayas and the American cordilleras, and Tapponnier et al.[1990] and Meyer [1991] for the mountain ranges of northeastern Tibet). Such large-scale folding appears to be the finite result of movement on high-angle thrusts that ramp from the lower crust towards the surface [e.g., Molnar, 1987; Molnar and Lyon-Caen, 1988; Tapponnier et al. 1990], rather than the result of finite amplitude buckling instabilities [e.g., Davy and Cobbold, 1988; Martinod, 1991]. Crustal ramp folding typically produces $3-8 \mathrm{~km}$ high, $20-60 \mathrm{~km}$ wide ranges and is probably the chief mechanism underlying the formation of continental mountain ranges of that size. These include the Aar and Mont-Blanc massifs in the western Alps [e.g., Menard and Thouvenot, 1987; Lacassin et al., 1990], the Sierra Nevada in southern Spain, the Mustagh Ata and Kongur Shan in the Pamirs, or the San Gabriel Mountains in California. The relatively simple and uniform "initial state" of most parts of Central Asia prior to the late Cenozoic reactivation (i.e., flat Cretaceous-Paleogene sedimentary blankets and vast, flat Paleogene peneplains, whose subsequent folding and faulting is particularly clear) makes it an ideal place to investigate various aspects of this mechanism.

At a more detailed level, where a flexural basin has developed in the foreland of the mountain ranges and when it has reached a depth of several kilometers and a width of several tens of kilometers, the geometry of such ranges is akin to that of a large fault-bend fold. The active ramp thrust under the rising core of the range remains blind. Instead of surfacing along the range front, that thrust flattens on decollements within or under the sediments of the foreland basin. Seeber et al. [1981], for instance, have long inferred the existence of such decollements south of the Himalayas from the position of isoseismals of great Indian earthquakes (e.g., 1934 Bihar-Nepal earthquake). If these decollements ultimately ramp to the surface, they will do so along the cores of active fault propagation anticlines deforming the sediments, several tens of kilometers away from the range front. If not, more gentle surface folds, also tens of kilometers away from the range, will be the surface expression of the blind tips of these propagating decollements. The growth of such folds is likely to involve widespread flexural slip, particularly on bedding planes dipping away from the main range, in effect a form of rotational bookshelf faulting distributing the displacement that cannot be absorbed by a throughgoing, localized thrust fault. The piedmont of the Tien Shan west of
Urumqi illustrates these processes remarkably well. Where the Manas flexural basin is deepest and widest, the active thrust has migrated farthest from the range front (Plate 1 and 2 and Figures 2 and 27). Towards the west, where that basin shallows (i.e., where the total thickness of Meso-Cenozoic sediments becomes less than $5 \mathrm{~km}$ ) the deep, high-angle thrust ramp emerges along a prominent active scarp right at the base of the range (Figure 2 and Plates 1 and 2 ). South of Manas, unmistakable evidence that an active high-angle thrust ramps to the surface within the main row of piedmont anticlines exists in the form of forelandfacing scarps across terraces in narrows that large antecedent rivers have incised into the cores of the anticlines (Figure 3 and Plates 2 and 3). Between Shawan and Dushanzi, the north limbs of the gentler anticlines of the more northerly row display instead spectacular examples of flexural slip on north dipping bedding planes, resulting in mountain-facing surface scarps (Plates 2 and 3 and Figure $3 b$ ). Such scarps have been observed in a similar environment of locally blind thrusting at the foot of the Qilian Shan [Tapponnier et al., 1990; Meyer, 1991].

The occurrence of foreland-facing scarps within narrow valleys entrenched in fault propagation anticlines or of mountain-facing scarps on the foreland-dipping limbs of gentler anticlines should in fact characterize high-angle emergent or flat blind active thrusts, respectively, in front of most rising mountain ranges that have deep foreland basins. A systematic search for such features might help alleviate the obstacle that the thick basin sediments, which smother faulting, oppose quantitative neotectonic work at the surface.

Although rendered more subtle by denser vegetation and faster degradation rates, those features may well exist, for instance, in the foreland of the $4-5 \mathrm{~km}$ high, still rising, external crystalline massifs of the western Alps.

We also see similarities between active shortening north of the Boro Horo range and south of the San Gabriel Mountains, although the overall tectonic environment there is one of fast, predominant strike-slip movement and the Los Angeles Basin, of pull apart origin [e.g., Hauksson and Stein, 1989, and references therein; Davis et al., 1989, and references therein]. The prominent surface scarp that marks the Cucamonga thrust [Morton and Matti, 1987] along the base of those mountains, to the east, stops north of Upland. West of that locality, and for at least $30 \mathrm{~km}$, Holocene surface faulting along the Sierra Madre fault, at the base of the San Gabriel Mountains is much less clear [Crook et al., 1987; C. Allen, personal communication, 1989]. The mountain front, however, is steep and shows youthful morphology, which implies that it must still be rising fast. That such uplift is active is attested by the occurence of the June 28, 1991, Mw= 5.7 Sierra Madre earthquake, that ruptured a $54^{\circ} \mathrm{NE}$ dipping thrust fault, $\approx 11 \mathrm{~km}$ deep and $\approx 15$ $\mathrm{km}$ north of the mountain front. South of it, as much as $12 \mathrm{~km}$ of sediments have accumulated in the Los Angeles basin [e.g., Davis et al., 1989]. A 150-km-long zone of active anticlines, the Elysian Park-Santa Monica Mountains fold zone, runs roughly E W, 20 to $40 \mathrm{~km}$ south of the mountain front [Davis et al., 1989; Hauksson and Jones, 1989, 1991; Lin and Stein, 1989]. Blind thrusting on a $10-15 \mathrm{~km}$ deep, $25^{\circ} \mathrm{N}$ dipping ramp and incremental folding of the surface occurred along a $6 \mathrm{~km}$ long segment of that zone during the October $1,1987, M L=5.9$ Whittier Narrows earthquake [Hauksson and Jones, 1989; Lin and Stein, 1989]. Southwest of Upland, the Elysian Park fold zone may merge with the subsurface San Jose fault [Hauksson and Jones, 1991]. Together, the June 1988, $M L=4.6$ and February $1990, M L=5.2$ Upland earthquakes ruptured $14 \mathrm{~km}$ of that $18-\mathrm{km}-\mathrm{long}$ fault, to a depth of $13 \mathrm{~km}$, but relieved only a fraction of the stress stored on the fault [Hauksson and Jones, 1991]. The focal mechanisms and aftershock locations of both shocks indicate left-lateral motion on the NE striking, $70^{\circ} \mathrm{NW}$ 
dipping fault, which may thus be interpreted to represent a leftlateral ramp linking the Cucamonga and Elysian Park thrusts [e.g., Hauksson and Jones, 1991].

Hence the upper crustal structure and surface morphology, as well as the faulting geometry and kinematics suggest that a mostly blind, high-angle crustal thrust ramp underlies the San Gabriel Mountains, which continue to grow along much of their length as a crustal fault-bend fold, as appears to be the case for the Boro Horo range. Where the Los Angeles basin is over 11 $\mathrm{km}$ deep, this active crustal thrust appears to have flattened under the foreland sediments and propagated to ramps underlying the Elysian Park-Santa Monica Mountains anticlinal zone [e.g., Davis et al., 1989; Hauksson and Jones, 1991]. In three dimensions, the transfer of shortening from the deep ramp under the San Gabriel Mountains to that zone is complex and may take place at different crustal levels but occurs mostly in two discrete steps, along the San Jose lateral ramp and the deeper Raymond lateral ramp, that ruptured during the December 1988, $M L=4.9$ Pasadena earthquake [e.g., Hauksson and Jones, 1991]. We view these two lateral ramps as analogous to those between $A 3$ and $A 6$, and across 66 , WSW of Shawan (Plate 2 and Figure 22).

The sequence of $5-15 \mathrm{~km}$ deep earthquakes of moderate magnitude $(4<M<6)$ that has recently shaken different areas of the San Gabriel Mountains foreland may thus be seen as having ruptured different shallow patches of the same complex thrust fault surface, a large crustal feature rooted under those mountains. This, as well as the temporal clustering of those earthquakes (i.e., the last five of 60 years of instrumental recording [Hauksson and Jones, 1991] suggests to us that they might be precursors of an impending, larger and deeper event originating on the crustal ramp beneath the mountains. If so, the greatest seismic hazard for the Los Angeles region would not lie on the shallow blind thrusts south of the San Gabriel Mountains but on that deep ramp, which probably merges with the San Andreas fault at depth and may be kinematically coupled with it. The magnitude of a large event on that ramp, of the 1906 Manas earthquake type, might exceed 7.5 if the mean slip were $2-4 \mathrm{~m}$ and if the rupture surface extended $50-100 \mathrm{~km}$ west of Cajon Pass. A detailed geological surface study of the Cucamonga fault would seem to be the fastest and cheapest way to obtain conclusive evidence on the existence, characteristic slip, and recurrence time of such an earthquake.

Outside subduction zones or compressional plate boundary segments (e.g., Transverse Ranges along the San Andreas fault, mentioned above), we know of few instances in which long-term shortening and uplift rates on active thrust faults have been estimated. Our work in the northern Tien Shan provides a range of such estimates and illustrates typical difficulties in obtaining them. First, there are fewer surface breaks due to thrust than to normal and strike-slip earthquakes, and there is growing evidence that most thrust earthquakes of moderate magnitude $(5.5<M<6.5)$ occur on blind faults [e.g., Stein and King, 1984; Stein and Ekström, 1992; Ekström et al., 1992]. Second, the rare thrust faults that reach the surface generally do so in complex ways, causing surface warping and forming multiple splays and discontinuous pressure ridges instead of a clean break. Moreover, because thrust faults usually dip less steeply than normal faults near the surface, their traces tend to migrate faster with increasing slip. As a result, slip rates are poorly known even on thrusts that have broken during earthquakes as extensively studied as that of 1980 at El Asnam (Ech Chliff), [e.g., Yielding et al., 1981; Philip and Meghraoui, 1983]. Rates of uplift or of shortening across folds may be inferred indirectly from rates of tilting or of incision, by rivers that cut them, of terrace surfaces [e.g., Rockwell et al., 1988], but for a direct, simple and fast determination of surface thrust-slip rate, clean cumulative thrust scarps must be found. Such scarps are rare in the area we studied, but short segments of them may be found across a few narrow valleys. There, by fortune, hundreds of meters of river incision provide direct access to portions of the rather steeply dipping $\left(55^{\circ} \pm 5^{\circ} \mathrm{S}\right)$ thrust ramps that lay concealed into the folds elsewhere. Along the scarps, the vertical throws of high terraces inferred from SPOT images to be coeval in all the valleys are found to be the same, of the order of $10 \mathrm{~m}$, with a standard deviation of less than $10 \%$. This remarkable uniformity not only justifies, post facto, the inference that the terraces are coeval but also that they were emplaced within a short time span during the last major climate warming, i.e., the beginning of the Holocene, now known to be globally synchronous at temperate latitudes $(10 \pm 2 \mathrm{ka})$, [Fairbanks, 1989; Gasse et al., 1991]. The uniform Holocene surface throw and thrust rate values we derive $(1.0 \pm 0.3 \mathrm{~mm} / \mathrm{yr}$ and $1.34 \pm 0.6 \mathrm{~mm} / \mathrm{yr}$, respectively) rely critically on this indirect estimate of the age of the terrace surfaces f1-f6. Note that this estimate is also a major source of uncertainty in the values obtained. Clearly, direct dating of the fan surfaces, one by one, is needed. Nevertheless, we feel that the mean thrust rate above is unlikely to be in error by more than $50 \%$. An indication of this is given by the degradation of inset terrace edges in the Tashi and Jingou He valleys, which implies not only uniform thrust and degradation rates during the Holocene (i.e, since the deposition of the fans $f 1$ to $f 6$ ) but also yields a mass diffusivity of $5.5 \pm 2.5 \mathrm{~m}^{2} / \mathrm{kyr}$ for a local surface throw rate of $1.1 \pm 0.3 \mathrm{~mm} / \mathrm{yr}$. The mean uniform surface throw and degradation rate values derived here for the northern Tien Shan are closely comparable to those estimated along two thrusts (Yumu Shan and Changma faults) in the Qilian Shan (1 to 2 $\mathrm{mm} / \mathrm{yr}$ and $3.3 \pm 1.7 \mathrm{~m}^{2} / \mathrm{kyr}$ ), a similar environment of active continental shortening with a slightly drier climate, for which the time scale is calibrated by the occurrence of the 180 A.D. Luo Tuo Chen earthquake [Tapponnier et al., 1990; Meyer, 1991].

Even if the mean thrust rate determined at the surface is correct, however, it must be considered a lower bound of the slip rate on the deep crustal ramp under the northern Tien Shan. This is because crustal shortening tends to be absorbed by folding and diffuse flexural slip within surface layers, making the relationship between slip at the surface and at depth more difficult to establish for thrusts than for other faults. We cannot be completely certain that the main surface trace of the 1906 , Ms $\approx 8.3$, Manas earthquake does not lie in the mountain south of She Chang [Bai and Fang, 1981], outside the zone we were granted access to. If correct, however, our interpretation that this earthquake activated the Tugulu-Dushanzi thrust, producing only the small $0.85 \pm 0.15 \mathrm{~m}$ high scarplets at Hutubi and Jingou $\mathrm{He}$ and greater free-faced extensional scarps related to hanging wall folding in the mountain, implies that about two thirds of the slip at depth are lost to folding and other diffuse strain before the surface is reached. With the thrust geometry deduced from geological maps and sections north of the mountain (Plates 2 and 3 and Figure 26), this conclusion derives mostly from the fact that a mean slip of $3.5 \pm 2 \mathrm{~m}$ at depth is required for better scaling with the rupture length and for producing a moment Mo of between 5.6 and $20 \times 10^{20} \mathrm{~N}$ m compatible with a magnitude $M w=8 \pm 0.2$ earthquake (Table 4). The resulting uplift rate would be $3+1.5 \mathrm{~mm} / \mathrm{yr}$.

Hence even great earthquake dislocations may have difficulty reaching the surface on continental thrusts. In spite of their size, such events may leave modest traces at the surface. In the foothills of the Tien Shan south of Manas, about a dozen earthquakes with magnitude greater than 8 appears to have in fact left a cumulative scarp only $10 \mathrm{~m}$ high and across a few 
valleys only. This observation, together with the fact that the recurrence of such great events might be of the order of 1000 years or more $(850 \pm 380$ years for the Boro Horo range), presumably explains why their occurrence has gone unnoticed and unforeseen under most ice-capped continental mountain ranges (for instance, the western Alps) save those where they occurred in the last 120 years. A corollary of this is that even when of modest height, cumulative thrust scarps of short length might be the telltale sign that great earthquakes do occur. Note that the rate of active shortening we infer on the deeper part of the Tugulu-Dushanzi thrust $(3 \pm 1.5 \mathrm{~mm} / \mathrm{yr})$ is not much different from that found for the Cucamonga fault $\approx 5 \mathrm{~mm} / \mathrm{yr}$ [Morton and Matti, 1987]). Nor is the total rate of present-day shortening we infer across the whole Tien Shan south of Manas $(6 \pm 3 \mathrm{~mm} / \mathrm{yr})$ very different from plausible values, consistent with plate tectonics, one might infer across the western Alps $(\approx 5 \mathrm{~mm} / \mathrm{yr}$ ). At the very least, the example of the northern Tien Shan should prompt us to take a serious second look.

Since deposition, the fans and high terraces that we infer to have formed near the onset of the Holocene (T0, f1-f6) have been rather deeply incised by the rivers flowing from the Boro Horo range, which implies rather fast rates of incision. In the Hutubi and Jingou He valleys, for instance, uniform rates of river incision of the order of $5 \mathrm{~mm} / \mathrm{yr}$ would be required to account for the $50 \mathrm{~m}$ entrenchment of the rivers into TO south of the Tugulu-Dushanzi thrust, if such entrenchment occurred in the last $10 \mathrm{kyr}$ (Table 4). That value seems typical of the most recent incision rates of large rivers in the Manas piedmont. It is nearly twice the average value inferred for the tectonic uplift rate due to thrusting and folding. That much of the incision is not of tectonic origin is corroborated by the fact that the rivers remain entrenched in their valleys far north of the thrust and associated folds (15-30 m for the Manas river according to Grenard [1929]). East of Shihozi, those rivers have incised a flat surface, standing at an elevation of about $300 \mathrm{~m}$, which appears to be coeval with the fans. We infer that surface to mark the high stand of a large ancient lake that flooded much of the flattish southwestern Dzoungarian basin during the early Holocene climatic optimum, forming lakes Manas and Ebi Nor and accounting for the high abandoned shorelines observed around the latter, now at an elevation of $189 \mathrm{~m}$ [Grenard, 1929]. We suggest that rapid foundering of the lake stand and of the associated base level, after $8 \mathrm{ka}$, as observed for similar post glacial lakes in Asia and Africa [e.g., Gasse et al., 1991], drove the fast and prominent incision of the rivers into their fans.

Assuming isostatic compensation, we have estimated finite shortening on north-south sections across the whole Tien Shan mountain belt by balancing the crustal area under the belt and by correcting for the effect of erosion using the volumes of late Cenozoic sediments deposited adjacent to the belt. Such a correction is feasible for the Tien Shan because none of the rivers born there reach the sea. The principal source of uncertainty in our estimates is the initial thickness (H1) of the crust under the belt. If a 2000 - m-high mountain range or a 1000 -m -deep ocean basin existed in the early Tertiary where the Tien Shan has now risen, then these estimates might be in error by as much as $40 \%$. We know of no clear evidence of such a high mountain or deep basin. Although marine Miocene foraminifera have been found in the westernmost Tien Shan (Fergana and Kashgar regions), they probably imply the existence of a shallow water body such as the modern Aral sea (E. Sobel, personnal communication, 1991). Until the geometry of this Miocene sea is known, it will remain difficult to assess quantitatively the bias it introduces in shortening estimates. We simply note that there might have been additional shortening in parts of the westernmost Tien Shan, perhaps locally as much as $50 \mathrm{~km}$. In the eastern Tien Shan, the existence of locally deeper Jurassic basins may explain why crustal shortening became localized where it did. If crustal ramp folding is the chief mechanism accounting for the formation of the Tien Shan south of Manas, then $124 \pm 30 \mathrm{~km}$ of shortening across the $220-\mathrm{km}-$ wide belt implies that it is composed of about four coalescent crustal anticlines. If the whole range had grown at a steady rate since $\approx 16 \mathrm{Ma}$, each anticline would have reached its maximum size in a few million years $(\approx 4 \mathrm{My}$ ). At the mantle level, 125 $\mathrm{km}$ of shortening seem sufficient to localize shear through the lithosphere. Hence continental subduction of the lithospheric mantle would have already started in the eastern Tien Shan, and should be well developed towards the west [e.g., Mattauer, 1986; Burov et al., 1990].

In map view, the positive westward gradient of shortening (about $10 \mathrm{~km} /{ }^{\circ} \mathrm{E}$ ) along the $1700 \mathrm{~km}$ long Tien Shan belt derived from our estimates implies $7 \pm 2.5^{\circ}$ of finite clockwise rotation of the Tarim relative to Kazakhstan and Dzungaria in the late Cenozoic. Qualitatively, this is a simple and robust consequence of the westward increase in width of the belt while its mean elevation remains roughly constant (between 2500 and $2900 \mathrm{~m})$. Both the paleomagnetic (8.6 $\pm 8.7^{\circ}$ [ Chen et al., 1991]) and tectonic results of our work are in agreement. Whereas the mean values obtained by either technique are similar $\left(7-9^{\circ}\right)$ and rather small, the tectonic estimate is apparently more accurate. Recall, nevertheless, that the latter might be little more than a lower bound if a wedge-shaped, eastward tapering Miocene basin existed where the Tien Shan now lies. Unless such a hypothetical basin were very deep or very wide, however, its existence would not incr :ase the amount of rotation by more than a few degrees. Wh le the sense of rotation of the Tarim relative to regions north of the Tien Shan had previously been inferred [e.g., England and Houseman, 1985; Cobbold and Davy, 1988], neither its amount nor the mechanism responsible for the rotation had been properly constrained or discussed prior to the paleomagnetic study of Chen et al[1991]. In a general sense, the mechanism of that rotation is strain heterogeneity in map view, which is particularly clear in the western part of the India Eurasia collision zone where the Tarim looms as such a large undeformable block and where the westwards widening Tien Shan may be seen as a northern counterpart of the eastwards narrowing Tibetan Plateau with which it overlaps [Molnar and Tapponnier, 1981; England and Houseman, 1985; Chen et al., 1991]. In more simple terms, the northwest prong of the Indian continent abuts almost directly the southwest tip of the Tarim through the narrow Karakorum and Pamirs, thus transmitting efficiently to it the thrust of collision. Towards the east, by contrast, much of the convergence is absorbed south of the Tarim or transferred east-southeastwards to South China by strike-slip motion along the Altyn Tagh, Kun Lun, and Xian Shui He faults. It is the stronger push in the west than in the east that causes the Tarim block, whose elongation is east-west, to rotate clockwise [Avouac et al., 1990; Chen et al., 1991].

Assuming steady state strain, the finite shortening and present rate values obtained suggest that the Tien Shan is a particularly recent mountain belt within the collision zone. It appears to have formed mostly in the Neogene, probably since the middle Miocene $(16+22 /-9 \mathrm{Ma})$, about $30 \mathrm{~m} . \mathrm{y}$. after collision started along the southern rim of Asia in the Eocene. This age is in keeping with that of the bulk of the sediments deposited in the basins that flank the mountain $(<25 \mathrm{Ma})$ and with the sharp early Neogene increase in subsidence and deposition rates in those basins [Hendrix et al., 1992]. That such a great range rose so fast so recently supports the view that discrete tectonic phases 
and changes in strain styles have occurred as deformation migrated northwards across the Asian continent with the penetration of India into it [Peltzer and Tapponnier, 1988; Tapponnier et al., 1982]. More specifically, we find it tempting to relate the onset of significant shortening in the Tien Shan in the middle Miocene with the cessation of seafloor spreading in the South China sea (15-16 Ma [Taylor and Hayes, 1983; Briais et al., 1992]), the end of large-scale left-lateral shear along the Red River Ailao Shan zone (after $\approx 21 \mathrm{Ma}$ [Tapponnier et al., 1990; Scharer et al., 1990, Leloup, 1991]), the cooling of highgrade Tertiary gneisses along that zone (from $\approx 19 \mathrm{Ma}$ onwards, (M. Harrison et al., unpublished manuscript, 1991)), as well as with the lower Miocene peak metamorphism on the MCT ( $\approx 20 \mathrm{Ma}$ [e.g., Hubbard and Harrison, 1989]), the fast cooling pulse in the Gangdese Shan of southern Tibet $(\approx 20 \mathrm{Ma}$ [Copeland et al., 1987]), and the onset of massive turbidite flux in the distal Bengal fan (somewhat prior to $\approx 17 \mathrm{Ma}$ [Cochran, 1987]), all of which may imply increased shortening, uplift and erosion rates in the Himalayas at that time, possibly correlative of the most rapid change in seawater $\mathrm{Sr}$ isotopic ratio, between 20 and $15 \mathrm{Ma}$ [Richter et al., 1992]. That there is growing evidence for a rough coevality between all these different events implies that they may all result from a single cause. We find that the most attractive solution is to view them as being orchestrated by a major change of regime (a mid-Miocene crisis) in the IndiaEurasia collision, as convergence between the two continents ceased to be chiefly absorbed by the extrusion of Indochina to be progressively taken up by predominant crustal thickening in Tibet and Central Asia. The mid-Miocene onset of crustal shortening in the Tien Shan implied by our study is thus in keeping with the hypothesis of two principal tectonic phases during the collision [Tapponnier et al., 1982, 1986; Zhao and Morgan, 1985; Copeland et al., 1987], and brings further support to models of continental deformation in which strain localization exerts important dynamic control on tectonic style [Peltzer and Tapponnier, 1988].

Acknowledgments. We thank the Engineering School of Xinjiang in Urumqi for the organisation and logistics of fieldwork. Programs Dynamique et Bilan de la Terre and Tectoscope of the Institut National des Sciences de l'Univers provided financial support. We thank $\mathrm{V}$. Courtillot, J.P. Cogné, and Chen Yan for their help with measurements in the field and for numerous discussions in the lab. We are also grateful to R. Armijo, R. Lacassin, Y. Gaudemer, and B. Meyer for thoughtfu] remarks and to $\mathbf{P}$. Molnar for a constructive review. P. Tapponnier, who felt both the 1988 Pasadena and the 1990 Upland earthquakes while at JPL and Caltech, gratefully aknowledges support from these institutions during those stays, which provided him wilh the opportunity to learn more on the active tectonics of the Los Angeles basin, particularly through discussions with C. Allen, K. Sieh, L. Jones, and E. Hauksson. Special thanks go to G. Aveline for the illustrations. This is IPGP contribution 1243.

\section{REFERENCES}

Abe, K., and S. Noguchi, Revision of magnitudes of large shallow earthquakes, 1897-1912, Phys. Earth Planet. Inter., 33, 1-11, 1983.

Andrews, D.J., and R.C. Bucknam, Fitting degradation of shoreline scarps by a non linear diffusion model, J. Geophys. Res., 92, 12,857-12,867, 1987.

Akademiya Nauk SSSR, Atlas of Earthquakes in the USSR (in Russian), Moscow, 1962.

Akademiya Nauk SSSR, Geologic map of Central Asia and adjacent regions, Moscow, 1964.

$\mathrm{Aki}, \mathrm{K}$., Generation and propagation of $G$ waves from the Niigata earthquake of June 16, 1964, 2, Estimation of earthquake momen released energy and sttress strain drop from the G-waves spectrum, Bull. Earthquake Res. Inst. Univ. Tokyo, 44, 73-88, 1966.

Argand, E., La tectonique de l'Asie, Proc. Int. Geol. Congr. 13th, 1, 171-372, 1924.
Armijo, R., P. Tapponnier, J.L. Mercier, and Han Tong Lin, Quaternary extension in Southern Tibet: field observations and tectonic implications, J. Geophys. Res., 91, 13,803-13,872, 1986.

Armijo, R., P. Tapponnier, and H. Tonglin, Late Cenozoic right-lateral strike-slip faulting in southern Tibet, J. Geophys. Res., 94, 27872838, 1989.

Avouac, J.P., Application des méthodes de morphologie quantitative à la néotectonique, Cinématique des Déformations actives en Asie Centrale, doctorat, Univ. Paris VII, 1991.

Avouac, J.P., Analysis of scarp profiles: evaluation of errors in morphological dating, J. Geophys. Res., this issue.

Avouac, J.P., P. Tapponnier, M. Bai, H. You, and G. Wang, Field evidence for active faulting and folding along the northern piedmont of the Tien Shan (Xinjiang, China) (abstract), Eos Trans. $A G U, 71$, $1561,1990$.

Bai, M., and Z. Fang, Relationship between phenomena of surface breaking and geological studies of the Malasi southwestern earthquake $(M=8)$ in 1906 in the Xinjiang region (in Chinese), Northwest. Seismol. J., 3(2), 100-102, 1981.

Bally, A. W., I. Ming Chou, R. Clayton, H.P. Heugster, S. Kidwell, L.D. Meckel, R.T. Ryder, A. B. Watts, and A. A. Wilson, Notes on Sedimentary basins in China, Report of the American Sedimentary Basins Delegation to the People's Republic of China, August 17September 8, 1985, U.S. Geol. Surv., Open File Rep., 86-327, 108 pp., 1986.

Bard E., B. Hamelin, R.G. Fairbanks, and A. Zindler, Calibration of the $14 \mathrm{C}$ timescale over the past 30000 years using mass spectrometric U-TH ages from Barbados corals, Nature, 345, 405-410, 1990.

Briais, A., P., Patriat, and P. Tapponnier, Updated interpretation of magnetic anomalies and seafloor spreading stages in the South China Sea: Implications for the Tertiary tectonics of S.E. Asia, J. Geophys. Res., in press, 1992.

Buffetaut, E., N. Sattayarak, and V. Suteethorn, A psittacosaurid dinosaur from the Cretaceous of Thailand and its implications for the palaeogeographical history of Asia, Terra Nova, 1, 370-373, 1989.

Burov, E.V., M.G. Kogan, H. Lyon-Caen, and P. Molnar, Gravity anomalies, the deep structure, and dynamic processes beneath the Tien Shan, Earth Planet. Sci. Lett., 96, 367-383, 1990.

Burtman, V. S., Structural geology of the Variscan Tien Shan, Am. J. Sci., 275A, 157-186, 1975.

Burtman, V. S., Faults of Midle Asia, Am. J. Sci., 280, 725-744, 1980.

Carroll, A. R., L. Yunhai, S. A. Graham, X. Xuchang, M. S. Hendrix, C. Jingi, and C. L. Mcknight, Junggar basin, northwest China: Trapped late Paleozoic ocean, Tectonophysics, 181, 1-14, 1990.

Chang, T., The Geology of China, 623 pp., C.C.M. Information Corporation, New York, 1959.

Chen, Z., N. Wu, D. Zhang, J. Hu, H. Huang, and G. Shen, Geological map of Xinjiang-Uygour Autonomous Region, scale 1/2 000000 , Bur. of Geol. and Miner. Ressour. of Xinjiang, Urumqi, 1985.

Chen, Y., J. P. Cogne, V. Courtillot, J. P. Avouac, P. Tapponnier, E. Buffetaut, G. Wang, M. Bai, H. You, M. Li, and C. Wei, Paeomagnetic study of Mesozoic continental sediments alonf the northern Tien Shan (China) and heterogeneous strain in Central Asia, J. Geophys. Res, 96, 4065-4082, 1991.

Cochran, J.R., Leg 116 shipboard scientific party, Ocean Drilling Project, College Station, Texas (abstract), Eos Trans. AGU, 68 , 1444, 1987.

Cobbold, P.R., and P. Davy, Indentation tectonics in nature and experiments, 2, Central Asia, Bull. Geol. Inst. Uppsala, 14, 143-162, 1988.

Copeland,P., T.M. Harrison, W.S.F. Kidd, Xu R., and Zhang Y., Parid early Miocene acceleration of uplif in the Gangdese Belt, Xizang (southern Tibet), and its bearing on the accomodation mechanism of the India-Asia collision, Earii Planet. Sci. Lett., 86, 240-252, 1987.

Crook, R., Jr., C.R. Allen, B. Kamb, C.M. Payne, and R.J. Serra Proctor, Quaternary geology and seismic hazard of the Sierra Madre and associated faults, western San Gabriel Mountains, in Recent Reverse Faulting in the Transverse Ranges, California, edited by D.M. Morton and R.F. Yerkes, U.S. Geol. Surv. Prof. Pap., 1339, 179-203, 1987.

Davis, T.L., J. Namson, and R.F. Yerkes, A cross section of the Los Angeles area: Seismically active fold and thrust belt, the 1987 Whittier Narrow eartquake, and earthquake hazard, J. Geophys. Res., 94, 9644-9665, 1989.

Davy, P., and P.R. Cobbold, Indentation tectonics in nature and 
experiments, 1, Central Asia, Bull. Geol. Inst. Uppsala, 14, 129-142, 1988.

Defense Mapping Agency, Operational navigational chart series, scale $1 / 1000$ 000, sheet 73, St. Louis, Miss., 1982.

DeMets, C., R.G. Gordon, D.F. Argus, and S. Stein, Current plate motions, Geophys. J. Int., 101, 425-478, 1990.

Derbyshire, E., A history of glacial stratigraphy in China, Quat. Sci. Rev., 6, 301-314, 1987.

Ding G., The Fuyun earthquake fault zone in Xinjiang, China (in Chinese), Seismol. Bur. of Xinjiang Uygur Autonomous Region, Urumqi, 1985.

Dong, Z.M., Dinosaurs from Wuerho, Mem., 11, pp. 1-7, of the Inst. of Vertebrate Palaeontol. and Palaeoanthropol. (in Chinese), Beijing, 1973.

Ekström, G., and A.M. Dziewonski, Evidence of bias in estimations of earthquake size, Nature, 332, 319-323, 1988.

Ekström, G., and P. England, Seismic strain rates in regions of distributed continental deformation, J. Geophys. Res., 94, 10231$10257,1989$.

Ekström, G., R.S. Stein, J. P.Eaton, and D. Eberhart-Phillips, Seismicity and geometry of a 110-km-long blind thrust thrust fault, 1: the 1985 Kettleman Hills, California, earthquake, J. Geophys. Res., 97, 4843-4864, 1992.

England, P., and G. Houseman, Role of lithospheric strength heterogeneities in the tectonics of Tibet and neighbouring regions, Nature, 315, 297-301, 1985.

Enkin, R., Yang Z., Chen Y., and V. Courtillot, Paleomagnetic constraints on the geodynamic history of the major blocks of China from the Permian to the present, J. Geophys. Res., 97, 13,95313,989, 1992.

Fairbanks, R.G., A 17000-year glacio-eustatic sea level record: Influence of glacial melting rates on the Younger Dryas event and deep-ocean circulation, Nature, 342, 637-642, 1989.

Florensov, N.A., and V.P. Solonenko, The Gobi-Altai Earthquake (in russian), Nauka, Moscow, 1963.

Gasse, F., M. Arnold, J. Ch. Fontes, M. Fort, E. Gibert, A. Huc, Y. Li, Q. Liu, F. Melères, E. Van Campo, F. Wang, and Q. Zheng, A 13,000 yr climatic record in western Tibet, Nature, Nature, 353, $742-745,1991$.

Goryachev, A.V., Mesozoic-Cenozoic Structure, History, Tectonic Development, and Seismicity of the Region of Lake Issyk-kul (in Russian), Academy of Sciences Publishing House, Moscow, 1959.

Graham, S.A., S. Brussel, A.R.. Carroll, X. Xiao, G. Demaison, C.L. McKnight, Y. Liang, J. Chu, and M.S. Hendrix, Characteristics of selected source petroleum source-rocks, Xinjiang Uygur Autonomous Region, northwest China, AAPG Bull., 74, 493-512, 1989.

Grenard, F., La Haute Asie, Géogr. Univ., vol. 8, 394 pp, Armand Colin, Paris, 1929.

Hanks, T. C., and R. E. Wallace, Morphological analysis of the Lake Lahontan shoreline and beachfront fault scarps, Pershing County, Nevada, Bull. Seismol. Soc. Am., 75(3), 835-846, 1985.

Hanks, T. C., R.C. Bucknam, K.R. Lajoie, and R.E. Wallace, Modification of wave-cut and faulting-controlled landforms, $J$. Geophys. Res., 89, 5771-5790, 1984.

Hao, Y.C., et al., The Cretaceous System of China, 301 pp., Geological Publishing House, Beijing, 1986.

Hauksson, E., and L.M. Jones, The 1987 Whittier Narrows Earthquake sequence in Los Angeles, Southern California: Seismological and tectonic analysis, J. Geophys. Res., 94. 9569-9590. 1991.

Hauksson, E., and L.M. Jones, The 1988 and 1990 Upland earthquakes: left-lateral faulting adjacent to the central Tranverses Ranges, J. Geophys. Res., 96, 8143-8165, 1991.

Hauksson, E., and R. S. Stein, The 1987 Whittier Narrows earthquake: A metropolitan shock, J. Geophys. Res., 94, 9545-9547, 1989.

Hedin, S., Southern Tibet,: discoveries in former times compared with my own researches, vol. VII, Trychery Artiebolaget Thule, Stockholm, 1922.

Hendrix, M.S., S.A. Graham, A.R. Carroll, E.R. Sobel, C.L. McKnight, B.J. Schulein, and Z. Wang, Sedimentary record and climatic implications of recurrent deformation in the Tian Shan: Evidence from mesozoic strata of the north Tarim, south Junggar, and Turpan basins, northwest China, Geol. Soc. Am. Bull., 104, 5379, 1992.

Hubbard, M.S., and T.M. Harrison, ${ }^{40} \mathrm{Ar} / 39 \mathrm{Ar}$ age constraints on deformation and metamorphism in the MCT zone and Tibetan slab, eastern Nepal, Himalaya, Tectonics, 8, 865-880, 1989.
Hsū, K.J., Origin of sedimentary basins of China, in Chinese Sedimentary Basins, Sedimentary Basins of the World, pp. 207-227, Elsevier, New York, 1989.

Institute of Geophysics, The Catalog of Strong Shocks of China, Academia Sinica, Beijing, 1976.

Kanamori $H$., The energy release in great earthquakes, J. Geophys. Res., 82, 2981-2987, 1977.

Khramov, N., Paleomagnetology, Springer-Verlag, New York, 1987.

Knauf, V.M., Relation between regional seismic zones and premesozoic structures of the Tien Shan, Bull Acad. Sci. USSR, Earth Phys., 7, 35-45, 1973.

Kosygin Y. A., and L. M. Parfenov, Tectonics of the Soviet Far East, in The Ocean Basins and Margins, vol. 5, pp. 377-412, edited by A. E. M. Nairm, M. Churkin and G.G. Stehli, Academy of Sciences Publishing House, Moscow, 1981.

Krestnikov, V. N., History of Development of Oscillatory Movements of the Earth's Crust of the Pamir and Neighboring Parts of Asia (in Russian), Academy of Sciences Publishing House, Moscow, 1962.

Lacassin, R., P. Tapponnier, and L. Bourjot, Culminations anticlinales et imbrication de la lithosphere dans les Alpes, apport du profil ECORS-CROP, C. R. Acad. Sci., 310, 807-814, 1990.

Leloup, P.H., Cinématique des déformations himalayennes dans la zone de cisaillement crustal de l'Ailao Shan-Fleuve Rouge, doctorat, Univ. Paris VII, 1991.

Li, Y.P., Z.K. Zhang, M. Mc Williams R. Sharps, Y. J. Zhai, Y.A. Li, Q. $\mathrm{Li}$, and A.Cox., Mesozoic paleomagnetic results of the Tarim craton: Tertiary relative Motion between China and Siberia, Geophys. Res. Lett. , 15, 217-220, 1988.

Li, Y.T., The Tertiary system of China, 362 pp., Geological Publishing House, Beijing, 1984.

Liao, Z., L. Lu, N. Jiang, F. Xia, F. Sun, Y. Zhu, S. Li, and Z. Zhang, in Carboniferous and Permian in the western part of the East Tianshan Mountains, in 11th Congress on Carboniferous Stratigraphy and Geology, Guideb. Excursion, vol. 4, 39 pp., Beijing, 1987.

Lin, J., and R.S. Stein, Coseismic folding, earthquake recurrence, and the 1987 source mechanism at Whittier Narrows, Los Angeles Basin, California, J. Geophys. Res., 94, 9614-9634, 1989.

Lyon-Caen, H., and P. Molnar, Constraints on the structure of the Himalaya from an analysis of gravity anomalies and a flexural model of lithosphere, J. Geophys. Res., 88, 8171-8191, 1983.

Lyon-Caen, H., and P. Molnar, Gravity anomalies and the structure of Western Tibet and the Southern Tarim basin, Geophys. Res. Lett., $11,1251-1254,1984$.

Ma, X., Lithospheric dynamic map of China and adjacent seas with explanatory notes, scale 1:4 000 0000, Geol. Pub. House, Beijing, 1987.

Martinod, J., Instabilités périodiques de la lithosphere (flambage, boudinage) en compression et en extension, doctorat, Univ. Rennes I, 1991.

Mattauer, M., Les subductions intracontinentales des chaînes tertiaires d'Asie et leurs relations avec les décrochements, Bull. Soc. Géol. Fr., 58, 143-157, 1986.

Ménard, G., and F. Thouvenot, Coupes équilibrées crustales: Méthodologie et application aux Alpes occidentales, Geodin. Acta Paris, 1, 35-45, 1987.

Meyer, B., Mécanisme des grands tremblements de terre et du raccourcissement crustal oblique au bord nord-est du Tibet, doctorat, Univ. Paris VI, 1991.

Meyer, B., J.P. Avouac, P. Tapponnier, and M. Meghraoui, Mesures topographiques sur le segment SW de la zone faillée d'El Asnam et interprétation mécanique des relations entre failles inverses et normales, Bull. Soc. Géol. Fr., 8, 447-456, 1990a.

Meyer, B., M. Meghraoui, P. Tapponnier, Guo Shunnin, Xiang Hongfa, Chen Zhitai, and Cai Shuahua, Comparaison morphologique des escarpements de failles normales et inverses synchrones du tremblement de terre d'El Asnam, Algérie (10 octobre 1980), C.R. Acad. Sci., 310, 139-145, 1990 b.

Molnar, P., Inversion of profiles of uplift rates for the geometry of dipslip faults at depth, with examples from the Alps and the Himalaya, Ann. Geophys., 87(06B), 663-670, 1987.

Molnar, P., and Q. D. Deng, Faulting associated with large earthquakes and the average rate of deformation in central and eastem Asia, $J$. Geophys. Res., 89, 6203-6228, 1984.

Molnar, P., and H. Lyon-Caen, some simple physical aspects of the support, structure and evolution of mountain belts, Spec, P. Geol. Soc. Am., 218, 1988. 
Molnar, P., and H. Lyon-Caen, Fault plane solutions of earthquakes and active tectonics of the Tibetan Plateau and its margins, Geophys. J. Int., 99, 123-153, 1989.

Molnar, P., and P. Tapponnier, Cenozoic tectonics of Asia: Effects of a continental collision, Science, 189, 419-426, 1975.

Molnar, P., and P. Tapponnier, A possible dependence of tectonic strength on the age of the crust in Asia, Earth. Planet. Sci. Lett., 52, 107-114, 1981.

Molnar, P., T.J. Fitch, and F.T. Wu, Fault plane solutions of shallow earthquakes and contemporary tectonics in Asia, Earth Planet. Sci. Lett., 19, 101-112, 1973.

Morton, D.M., and J.C. Matti, The Cucamonga fault zone: Geologic setting and Quatemary history, in Recent Reverse Faulting in the Transverse Ranges, California, edited by D. M. Morton and R. F. Yerkes, U.S. Geol. Surv. Prof. Pap., 1339, 179-203, 1987.

Nash, D. B., Morphological analysis of degraded normal fault scarps, $J$. Geol. , 88, 353-360, 1980.

Nelson, M. R., R. McCaffrey, and P. Molnar, Source parameters for 11 earthquakes in the Tien Shan, Central Asia, determined by $\mathrm{P}$ and SH waveform inversion, J. Geophys. Res., 92, 12629-12648, 1987.

$\mathrm{Ni}$, J., Contemporary tectonics in the Tien Shan region, Earth Planet. Sci. Lett., 41, 347-355, 1978.

Norin, E., Geology of the Quruq Tagh: Eastern Tien Shan, Reports from the Scientific Expedition to the Northwestem Provinces of China under the leadership of Dr. Sven Hedin, (III), Geology 1, Bokforlags, Aktiebolaget Thule, Stockholm, 1937.

Norin, E., Geologic Reconnaissances in the Chinese Tien shan, Reports from the Scientific Expedition to the Northwestern Provinces of China under the leadership of Dr. Sven Hedin, (III), Geology 6, Bokförlags, Aktiebolaget Thule, Stockholm, 1941.

Peltzer, G., and P. Tapponnier, Formation and evolution of strike-slip faults, rifts, and basins during the India-Asia collision: An experimental approach, Journal of Geophys. Res., 93, 15,08515,117, 1988.

Peltzer, G., P. Tapponnier, Zhang Z. T., and Xu Z. Q., Neogene and Quatemary faulting in and along the Qin Ling Shan, Nature, 317, 500-505, 1985.

Peltzer, G., P. Tapponnier, Y. Gaudemer, B. Meyer, S. Guo, K. Yin, C. Chen, and H. Dai, Offsets of late Quaternary morphology, rate of slip and recurrence of large earthquake on the Chang $\mathrm{Ma}$ fault (Gansu, China), J. Geophys. Res., 93, 7793-7812, 1988.

Peltzer G., P. Tapponnier, and R. Armijo, Magnitude of Late Quatemary Left-Lateral Displacements along the North edge of Tibet, Science, 246, 1285-1289, 1989.

Peng, $X$., and $G$. Zhang, Tectonic features of the Junggar basin and their relationship with oil and gas distribution, in Chinese Sedimentary Basins, Sedimentary Basins of the World, pp. 17-31, Elsevier, New York, 1989.

Philip, H., and M. Meghraoui, Structural analysis and interpretation of the El Asnam earthquake of October 10, 1980, Tectonics, 2, 17-49, 1983.

Richter, F.M., D.B. Rowley, and D.J. DePaolo, Sr isotope evolution of seawater: the role of tectonics, Earth Planet. Sci. Lett., 109, 11-23, 1992.

Rockwell, T.K., E.A. Keller, and G.R. Dembroff, Quatemary folding of the Ventura anticline, westem Transverse Ranges, southerm California, Geol. Soc. Am. Bull., 100, 850-858, 1988.

Schärer, U., P. Tapponnier, R. Lacassin, P.H. Leloup, Z. Dalaï and J. Schaocheng, Intraplate tectonics in Asia: a precise age for the largescale Miocene movement along the Ailo Shan-Red River shear zone, China, Earth Planet. Sci. Letr., 97, 65-77, 1990.

Scholz, C.H., Scaling laws for large earthquakes: Consequences for physical models, Bull. Seismol. Soc. Am., 72, 1-14, 1982.

Scholz, C.H., C.A. Aviles and S.G. Wenousky, Scaling differences between large interplate and intraplate earthquakes, Bull. Seismol. Soc. Am. , 76, 65-70, 1986.

Schwartz, D.P., and K.L. Coppersmith, Fault behavior and characteristic earthquake: Examples on the Wasatch and San Andreas fault zones, J. Geophys. Res., 89, 5681-5698, 1984.

Seeber, L., J.G. Armbruster, and R.C. Quittmeyer, Seismicity and continental subduction in the Himalayan arc, in Zagros, Hindu Kush, Himalaya: Geodynamic Evolution, Geodyn. Ser., vol. 3, edited by H.
K. Gupta and F. M. Delany, pp. 215-242, AGU, Washington, D. C., 1981 .

Stein, R.S., and G. Ekström, Seismicity and geometry of a 110-km-long blind thrust thrust fault, 2, Synthesis of the 1982-1985 California earthquake sequence, $J$. Geophys. Res., 97, 4865-4883, 1992.

Stein, R.S., and G.C.P. King, Seismic potential revealed by surface folding: 1983 Coalinga, California, earthquake, Science, 224, 869872, 1984.

Suppe, J., Geometry and Kinematics of fault bend folding, Am. J. Sci., 283, 684-721, 1983.

Suppe, J., and D.A. Medwedeff, Fault propagation folding, Geol. Soc. Am. Abstr. Programs, 16, 670, 1984.

Tapponnier, P., and P. Molnar, Active faulting and Cenozoic tectonics of China, J. Geophys. Res., 82, 2905, 2930, 1977.

Tapponnier, P., and P. Molnar, Active faulting and Cenozoic tectonics of the Tien Shan, Mongolia and Baykal regions, J. Geophys. Res., 84, 3425-3459, 1979.

Tapponnier, P., G. Peltzer, R. Armijo, On the mechanics of the collision between India and Asia, in Collision tectonics, edited by M.P. Coward and A.C. Ries, Pp. 115-157, Geol. Soc. London, Spec. Publ. 19, 1986.

Tapponnier, P., G. Peltzer, A.Y. Le Dain, and R. Armijo, Propagating extrusion tectonics in Asia: New insights from simple experiments with plasticine, Geology, 10, 611-616, 1982.

Tapponnier, P., et al., Active thrusting and folding in the Qilian Shan, and decoupling between upper crust and mantle in northeastern Tibet, Earth Planet. Sci. Lett., 97, 382-403, 1990.

Taylor, B., and D.E. Hayes, Origin and history of the South China Basin, in The tectonic and geologic evolution of the southeast Asian seas and islands, edited by D.E. Hayes, Geophys. Monogr. Ser., 27, pp. 23-56, A.G.U., Washington, D.C., 1983.

Tian Z., G. Chai, and Y. Kang, Tectonic evolution of the Tarim Basin, in Chinese Sedimentary Basins, Sedimentary Basins of the World, pp. 33-42, Elsevier, New York, 1989.

Times Books, Times Atlas of the World, London, 1978.

Ulomov, V.I., Dynamics of the Earth's Crust and Prediction of Earthquakes (in Russian), 214 pp., Fan, Tashkent, 1974.

Voitovitch, V.S., Nature of the Dzungarian deep fault (in Russian), Tr. Geol. Inst. Akad. Nauk SSR, 183, 189 pp., 1969.

Wang, S., The Jurassic System of China, 350 pp., Geological Publishing House, Beijing, 1985.

Watson, J.B., A.B. Hayward, D.M. Parkinson, and Z.M. Zhang, Plate tectonic history, basin development and petroleum source rock deposition onshore China Sea, Mar. Pet. Geol., 4, 205-225, 1987.

Windley, B. F., M. B. Allen, C. Zhang, Z.Y. Zhao, and R.R. Wang, Paleozoic accretion and Cenozoic redeformation of the Chinese Tien Shan Range, Central Asia, Geology, I8, 128-131, 1990.

Wu Qingfu., Structural evolution and prospects of Junggar basin (in Chinese with English abstract), Xinjiang Geol., 4, 1-19, 1986.

Wu Z., Characteristics of evolution and division of tectonic structures in Junggar basin and the appraisal of gas and oil (in Chinese with English abstract), Xinjiang Geol., 4, 20-34, 1986.

Yielding, G., J.A. Jackson, G.C.P. King, H. Sinvhal, C. Vita Finzi, and R.M. Wood, Relation between surface deformation, fault geometry, seismicity and rupture characteristic during the El Asnam (Algeria) earthquake of 10 October 1980, Earth Planet. Sci. Lett., S6, 287-304, 1981.

Zhang, L.C., and N.Y. Wu, The geotectonic evolution of Tien Shan, Xinjiang Geology, 3(3), 1-14, 1985.

Zhao, W.L., and W. J. Morgan, Uplift of the Tibetan plateau, Tectonics, 4, 359-369, 1985.

J.P. Avouac, LDG/CEA, B.P. 12, 91680 Bruyères-le-Châtel, France. M. Bai, Bureau of Seismology of Xinjiang, Urumqi, Xinjiang, People's Republic of China.

P. Tapponnier, Laboratoire de Tectonique, IPGP, 4 place Jussieu, 75252, Paris, France.

M. You and G. Wang, Xinjiang Engineering Institute, Urumqi, Xinjiang, People's Republic of China.
(Received October 29, 1991; revised July 29, 1992 ; accepted August 28, 1992) 